\title{
Monitoring skill potentials for technological innovation and diffusion
}

Citation for published version (APA):

Hoevenberg, J., \& de Grip, A. (1994). Monitoring skill potentials for technological innovation and diffusion. Researchcentrum voor Onderwijs en Arbeidsmarkt, Faculteit der Economische Wetenschappen. ROA Reports No. 14E https://doi.org/10.26481/umarep.199414E

Document status and date:

Published: 01/01/1994

DOI:

10.26481/umarep.199414E

Document Version:

Publisher's PDF, also known as Version of record

\section{Please check the document version of this publication:}

- A submitted manuscript is the version of the article upon submission and before peer-review. There can be important differences between the submitted version and the official published version of record.

People interested in the research are advised to contact the author for the final version of the publication, or visit the DOI to the publisher's website.

- The final author version and the galley proof are versions of the publication after peer review.

- The final published version features the final layout of the paper including the volume, issue and page numbers.

Link to publication

\footnotetext{
General rights rights.

- You may freely distribute the URL identifying the publication in the public portal. please follow below link for the End User Agreement:

www.umlib.nl/taverne-license

Take down policy

If you believe that this document breaches copyright please contact us at:

repository@maastrichtuniversity.nl

providing details and we will investigate your claim.
}

Copyright and moral rights for the publications made accessible in the public portal are retained by the authors and/or other copyright owners and it is a condition of accessing publications that users recognise and abide by the legal requirements associated with these

- Users may download and print one copy of any publication from the public portal for the purpose of private study or research.

- You may not further distribute the material or use it for any profit-making activity or commercial gain

If the publication is distributed under the terms of Article $25 \mathrm{fa}$ of the Dutch Copyright Act, indicated by the "Taverne" license above, 


\section{Monitoring Skill Potentials for Technological Innovation and Diffusion}

ROA-R-1994/14E

J. Hoevenberg

A. de Grip

Research Centre for Education and the Labour Market

Faculty of Economics and Business Administration

University of Limburg

Maastricht, November 1994 


\section{CIP-GEGEVENS KONINKLIJKE BIBLIOTHEEK, DEN HAAG}

Hoevenberg, J.

Monitoring skill potentials for technological innovation and diffusion / J. Hoevenberg, A. de Grip. Maastricht : Research Centre for Education and the Labour Market, Faculty of Economics and Business Administration, University of Limburg. - (Report / Research Centre for Education and the Labour Market, ISSN 0922-8098; ROA-R-1994/14E)

Met lit. opg.

ISBN 90-5321-147-0

Trefw.: arbeidsmarkt ; technische beroepen ; Nederland. 


\section{Contents}

Page

1 Introduction 1

2 The labour force $\quad 3$

$\begin{array}{ll}2.1 \text { Introduction } & 3\end{array}$

2.2 The educational level of the labour force 3

2.3 Unemployment and labour market perspectives $\quad 9$

$\begin{array}{ll}2.4 \text { Flexibility of the labour force } & 22\end{array}$

$\begin{array}{llr}3 & \text { Initial education } & 27\end{array}$

$\begin{array}{lr}3.1 \text { Introduction } & 27\end{array}$

$\begin{array}{lr}3.2 \text { Public expenditure } & 27\end{array}$

$\begin{array}{lr}3.3 \text { Higher education } & 30\end{array}$

$\begin{array}{ll}3.4 \text { Vocational education } & 35\end{array}$

3.5 Unemployment and labour market prospects for Dutch school-leavers 44

4 Continuing Vocational Training $\quad 49$

5 Conclusion $\quad 53$

$\begin{array}{lr}\text { References } & 57\end{array}$

$\begin{array}{lr}\text { Appendix } & 59\end{array}$ 
$\ldots \ldots$ 


\section{Introduction}

Technological developments and labour influence one-another. On the one hand, technological change leads to changing demands for capacities and skills of the workforce, while on the other hand certain skills and capacities of the labour force are a necessary condition for technological development. Technological progress not only has a tremendous impact on the growth of the national economy and shifts in the economic structure, it also influences the size and the composition of employment, the contents of jobs, and the education required to fulfil these jobs adequately. In addition to specific consequences due to particular changes in technology, the high rate of innovation can itself lead to extra insecurities and thus to demands for more highly skilled workers. The educational level of the labour force is therefore an important determinant of the diffusion of technological innovations.

For several reasons, an adequate technology policy requires a solid understanding of the development of human capital potentials in the workforce. First, the skills of the workers largely determine the innovative potential of society. Second, technological developments make high demands on management capacities, due to the insecurities that arise from product and process innovations. Third, the skill level of the workforce is a major determinant of the speed of diffusion processes. And, last but not least, technological developments mean that skills become obsolete relatively rapidly.

The European Commission's 'White Paper' signals the great problems in maintaining and eventually expanding employment in the European Union (European Commission, 1993). At the end of the 1980s, a period in which the European economy was booming, 12 million people in the European Union were still unemployed. In 1993, the number of unemployed workers rose to over 17 million. The 'White Paper' describes several causes for this high unemployment.

- Europe has not succeeded in obtaining a sufficiently solid position in the international labour order: the labour markets of the future have been neglected because the Member States of the European Union placed too much emphasis on the traditionally strong sectors.

- The relatively high costs of low skilled workers stimulated capital investments and impeded the creation of jobs in the service sector.

- Many newly-industrialised countries (NICs) have begun to compete with the European Union Member States, while the European Union is not capable in competing with these countries on cost levels.

In order to increase employment levels, the European Union has to catch up in the technological race. This point had been stressed before by the European Round Table of Industrialists (1989). Similar arguments were raised in the public debate in the USA in the 1980s: Our trading partners have realized that their productivity will determine both their international power and standard of living. These countries have made substantial commitments to educate and train their workforces. America has, in many respects failed to do the same (U.S. Department of Labor, 1989, p. 1). For the Netherlands the commitment to educate and train the Workforce is stated in an advice of the Social Economic Counsil (SER, 1994), regarding the period 1994-1998. Especially attention is given in this respect to the training of the lower skilled and unemployed.

Rapid technological change offers great opportunities for increasing employment in the European Union. However, to be able to profit from this technological development, the labour force must become more flexible. Apart from the short-term labour flexibility which is facilitated by the growth of various forms of atypical employment relations such as part-time work, temporary contracts, etc (see e.g. Treu, 1992 and De Grip, Hoevenberg and Willems, forthcoming), long-term flexibility is also crucial. The main source of 
this long-term flexibilisation of the labour force is continuing vocational training (see also e.g. Delsen, 1991). According to the 'White Paper' this should be established by creating a system of permanent learning.

Human capital, generated by both initial education and continuing training, and technological development are two blades of one pair of scissors. Both are crucially important for a country's competitive position.

This report focuses on the available key indicators of the technological potential of the labour force, and in particular on the two forms of human capital mentioned above. The indicators presented refer to the technological potential of the labour force as an indication of the fertility of the breeding ground for technological development. The indicators are part of a database on the international economic position of the Netherlands with regard to the implementation of technology, called STEMMING. The STEMMING database has been developed by the Maastricht Economic Research Institute on Innovation and Technology (MERIT) for the Directorate for Technology Policy of the Directorate-General for Economic Structure of the Ministry of Economic Affairs. Although this report can be seen as an update of earlier studies (see Van Dam and De Grip, 1990), its design has been changed drastically. Rather than simply providing a summary of the updated key indicators and some incidental surveys, the various indicators are now presented in the framework of a more thematic approach. Moreover, developments are illustrated in a more graphical way.

Where possible, the report compares the Netherlands with four countries that have similar economies (Austria, Denmark, Sweden and Switzerland) and the five G-7 countries (France, Germany, Japan, the United Kingdom and the United States). Unfortunately, it has not always been possible to present all these countries. In some cases, where data was not available for all these countries, other countries have been included, based on data availability.

The report is structured as follows. Chapter 2 focuses on the labour force. Here we look at the educational level of the labour force, unemployment and labour market prospects and the flexibility of the labour force, in general terms. Chapter 3 presents some trends in initial education. The number of students in initial education, together with all kinds of training activities, determines in broad terms the future evolution of skills in the workforce. The educational level of the workforce determines how rapidly technologies will be diffused and how easily the labour force can adapt to new technologies. In this chapter we also provide separate overviews of higher education and vocational education. The chapter concludes with some developments in the unemployment levels of Dutch school-leavers. Chapter 4 concentrates on continuing vocational training. In chapter 5 we present some general conclusions regarding the capability of the Dutch labour force to adapt to technological change in relation to the international situation. Finally, the appendices describe the actual data on which the graphs in the chapters 2, 3 and 4 are based. 


\section{The labour force}

\subsection{Introduction}

In times of rapid technological change the flexibility of the labour force is very important for a country's competitive position. As Spenner (1985) argues, technological change can affect the labour force in three ways. First, there may be an upgrading of the skill level required of the workforce. This means that technological development requires more skills, greater responsibility and greater flexibility, to operate in a changing environment, and thus leads to an increased skill level (see e.g. Rumberger \& Levin, 1989). The second possible effect of technological developments is a downgrading of the skill level. This is the case if technological developments make tasks simpler, and will lead to de-skilling of employment (see e.g. Braverman, 1974). The third possible outcome is mixed and offsetting movements, a combination of upgrading and downgrading effects. As Bartel \& Lichtenberg (1987) point out, in the first stages of the introduction of a technological innovation there will be an upgrading in the workforce, while in the later stages of the production process life-cycle there will be a downgrading tendency. At the national level this could mean that the final outcome will show little net change in the skill requirements, as the required skills in some occupations will be upgraded while skills required in others will be downgraded.

However, keeping in mind the relatively high wages of the more developed countries, one would expect that technological development should in general lead to upgrading of the workforce. However, in the long term the influence is mutual, as the high educational level of the workforce is a necessary condition for the development and use of new technologies. Upgrading of the labour force can take place in two ways: by means of recruitment policies or training policies. In the first case more highly skilled people are recruited, in the latter case the current workforce is trained (see also Groot and De Grip, 1991). The result of both options is an increase in the quality of the available human resources. Moreover, to be able to keep up with technological developments, the labour force has to become more flexible, so as to be able to adapt quickly to new circumstances. The most important factor in increasing long-term flexibility is continuing vocational education, which will be dealt with in chapter 4 . However, to be able to provide the workforce with the training it needs, a certain initial skill level is required anyway. Therefore the skill level of the workforce will first be analyzed, in section 2.2. In section 2.3 we consider the unemployment and labour market prospects in some OECD countries. Finally, in section 2.4 we analyze the 'adaptability' of the labour force.

\subsection{The educational level of the labour force}

\section{The educational level of the workforce}

Graphs 2.1 to 2.3 show the proportions of the labour force that have completed a certain level of education. The educational level of the labour force is an indicator of differences in the competitive position of countries with regard to innovative capacities (higher proportions of highly-educated workers improve the innovative potential of the country), flexibility in introducing product or process innovations and more rapid diffusion processes, since a more educated labour force adapts more easily to changes in technologies. Graph 2.1 clearly shows that the employment share of the low skilled workers is decreasing, and that there are very large differences between countries. ${ }^{1}$ The employment shares for

1. The annual OECD report Education at a glance contains a warning about the interpretation of the levels of education. The results must be regarded with some caution because the countries do not always classify diplomas and qualifications taken at roughly the same age or after a similar number of years of schooling at the same ISCED level. 
low skilled workers (see graph 2.1) range from about $50 \%$ of the workforce in France to $17 \%$ of the workforce in the United States, but the share is decreasing in all countries. This is a first indication that there is a general upgrading tendency for all countries. In most countries the employment share of those with intermediate level education has increased (graph 2.2), except in Germany, where their employment share decreased slightly. On the other hand, in Germany there has been a large increase in the employment share of those with higher education. The same holds for France. However the United States has the highest employment share of the highly-skilled workers.

Graph 2.1

Employment share of low skilled workers (ISCED 0/1/2) in the workforce aged 25-64, 1989 and 1991

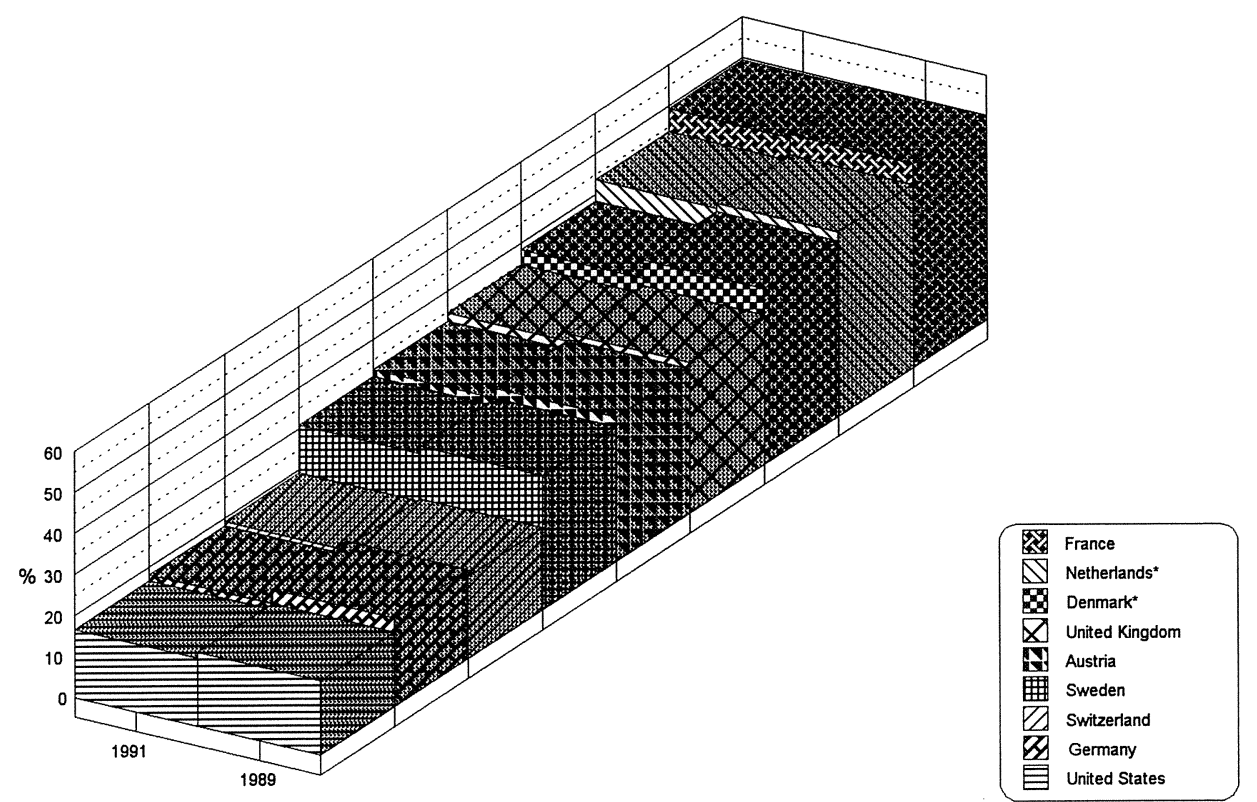

The employment share for the Netherlands in 1989 relates to 1990 data. The employment share for Denmark in 1989 relates to 1988.

Source: OECD

The overall picture for the United States is rather peculiar. Knowing that it normally takes about 12 years of education to complete the higher stage of secondary education and 13 to 16 years of education to complete higher education, this means that in this country over $80 \%$ of the workforce has completed at least 12 years and over $35 \%$ of the workforce completed more than 13 years of education. These figures are far above the human capital investments in any other country mentioned in the graphs. In most countries the employment shares of the low skilled workers are larger or at least about equal to the employment shares of the highly-skilled part of the workforce.

Focusing on the Dutch position, the overall conclusion must be that the Netherlands can be placed at the lower end of the spectrum. The graphs show that the main reason for this is the relatively large number of low skilled and the relatively small number of intermediate skilled workers. At the higher skill level the position of the Netherlands is in line with countries such as Denmark, Switzerland and Germany.

Also, countries apply different principles in classifying individuals by educational levels. Some countries use the number of adequately completed years of schooling at a certain level as the criterion for classification. Others use information about diplomas obtained, and a third group of countries uses both methods. 
Graph 2.2

Employment share of intermediate skilled workers (ISCED 3) in the labour force aged 25-64, 1989 and 1991

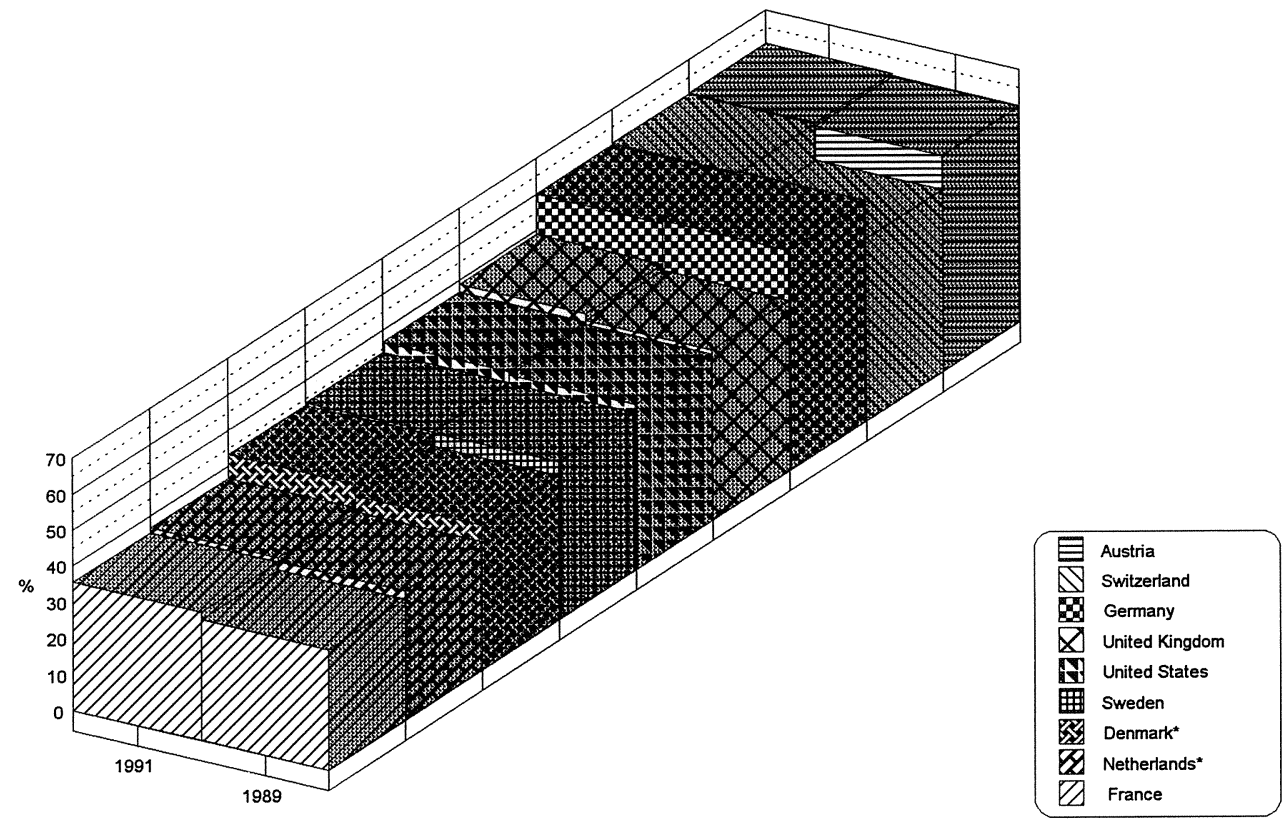

The employment share for the Netherlands in 1989 relates to 1990 data. The employment share for Denmark in 1989 relates to 1988.

Source: OECD

Graph 2.3

Employment share of highly skilled workers (ISCED 5/6/7) in the labour force aged 25-64, 1989 and 1991

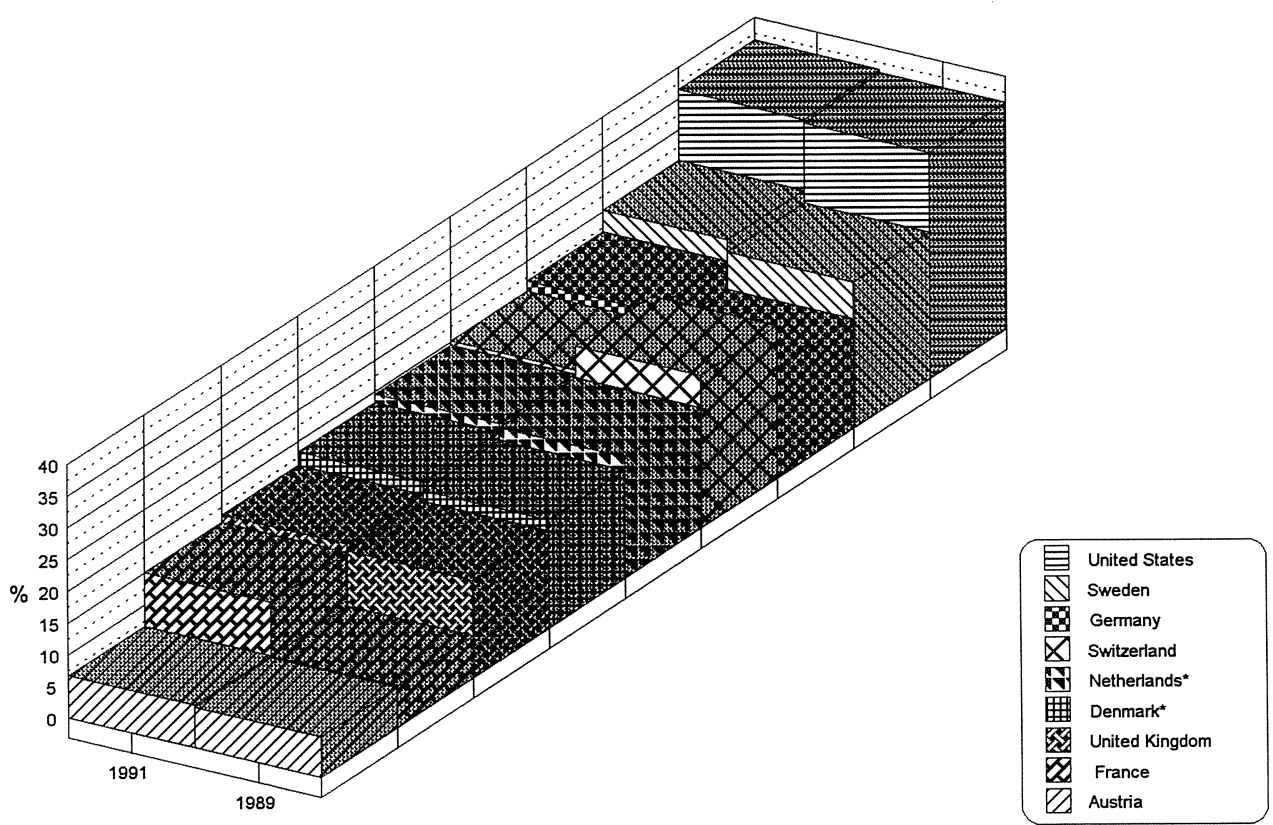

The employment share for the Netherlands in 1989 relates to 1990 data. The employment share for Denmark in 1989 relates to 1988.

Source: OECD 
According to Ryan (1991), the intermediate skilled workers have an important position in the upgrading process. Ryan also emphasizes the importance of an adequate supply of intermediate skilled workers for the efficiency of the production process, in contrast to the more usual notion, based on humancapital theory, that a higher skill level is always reflected in higher productivity. However, in an analysis of the international competitive position of economic sectors in the United Kingdom and the USA, Daly (1986) finds that a difference in the employment shares of highly-skilled workers has a significant positive effect on relative labour productivity, whereas a higher share of intermediate skilled workers did not have the expected positive effect on the relative labour productivity of an economic sector. The results of Ryan and Daly may probably be combined in the assumption that an optimal mixture of highly and intermediate skilled workers is needed for a maximum labour productivity.

Hoevenberg and De Grip (1994) have examined the average educational levels of the working population in various occupational sectors in some European Union countries over the period 1988 1991. ${ }^{2}$ Graphs 2.4 and 2.5 show the employment shares of intermediate and highly-skilled workers, respectively, in 1991.

Graph 2.4a

Employment shares of intermediate skilled workers by occupational sectors in $1991^{3}$

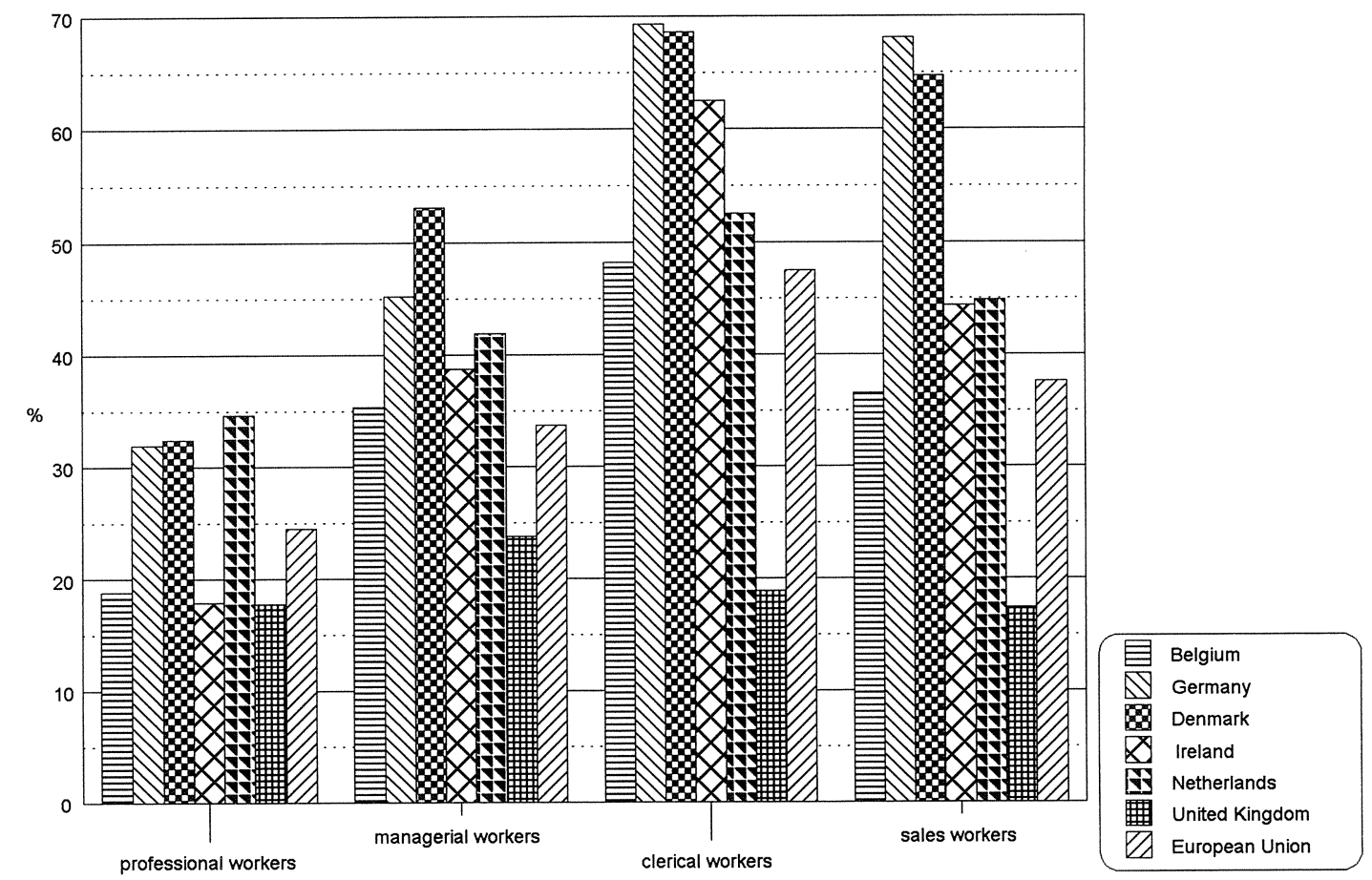

Source: EUROSTAT/ROA

2. The results of this report are not comparable with the OECD data, since Hoevenberg and De Grip used data provided by EUROSTAT, based on a different definition of educational levels.

3. In the European Union figures, Italy and France are excluded. The figures for Germany are based on the (former) Federal Republic of Germany. 
Graph 2.4 indicates that the intermediate skilled workers have relatively large employment shares in all occupational sectors. The relatively low employment shares of intermediate skilled workers in the United Kingdom, in almost all occupational sectors, are remarkable. The difference between the United Kingdom and other countries on this measure is greater than the difference which appeared when considering the overall number of intermediate skilled workers, as shown in graph 2.2. This is the result of differences between the OECD and EUROSTAT definitions. ${ }^{4}$ Looking at the occupational sectors, we can see that it is especially in the occupational sectors of clerical workers and sales workers, that intermediate skilled workers have very high employment shares, even exceeding $60 \%$ in Germany and Denmark. These two countries have relatively high employment shares for intermediate skilled workers in all occupational sectors. In the case of Germany, this is probably due to the widespread apprenticeship system (see Marsden \& Ryan, 1991).

Graph $2.4 b$

Employment shares of intermediate skilled workers by occupational sectors in 1991

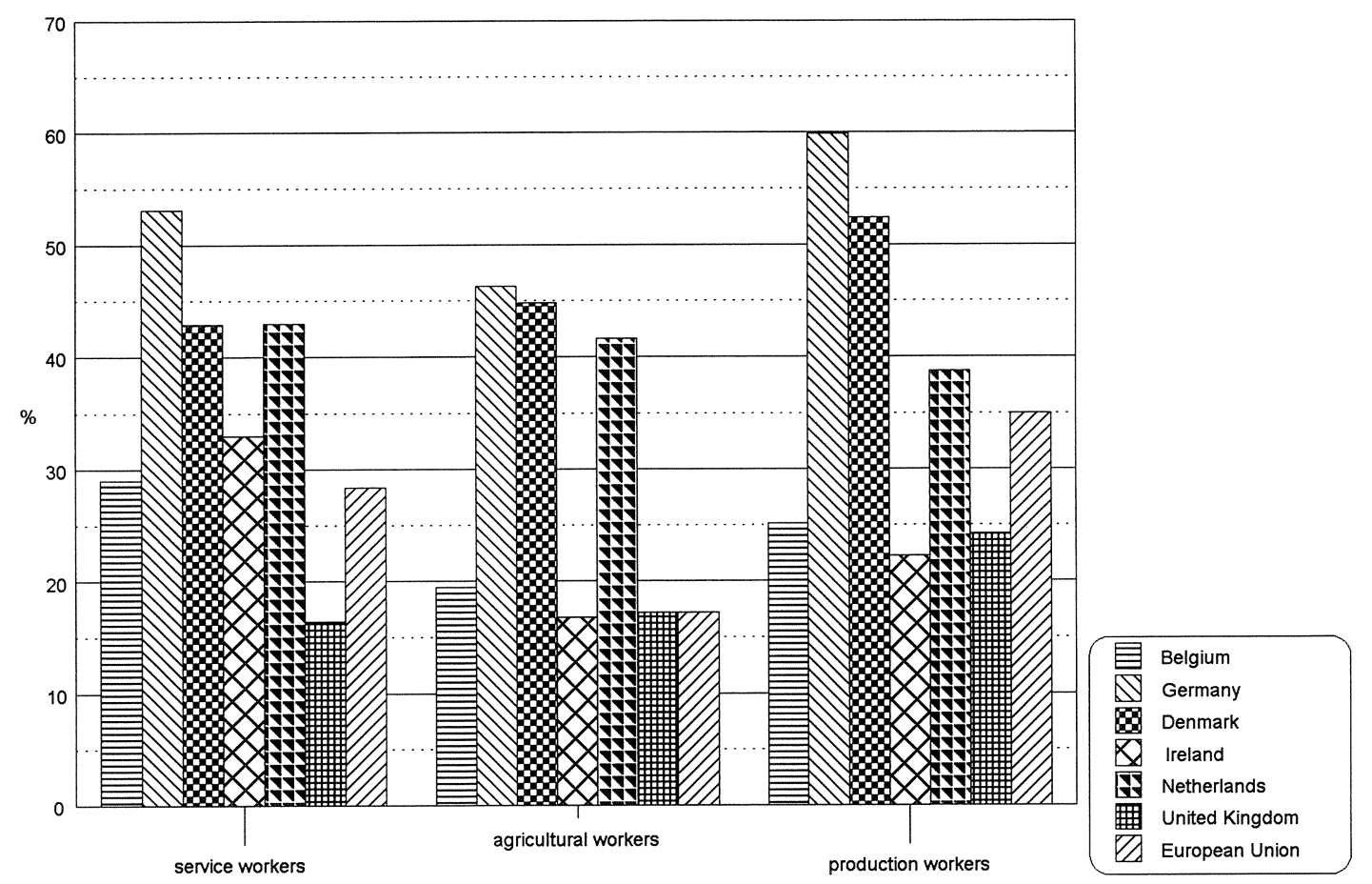

Source: EUROSTAT/ROA

Graph 2.5 shows the employment shares of highly-skilled workers in the various occupational sectors. In the occupational sector of professional workers, the employment share of highly-skilled workers is above $50 \%$ in every country. In Belgium and Ireland, 3 out of 4 people employed in this occupational sector are highly-skilled. However, less than $10 \%$ of production workers and service workers are highly-skilled.

4. This is largely because, in the EUROSTAT data, the former O-levels (General Comprehensive Secondary Education, general education to the age of 16) in the United Kingdom are considered as lower education, whereas the OECD places them in the intermediate segment. The EUROSTAT definition seems to be the more appropriate one. For a more comprehensive description of the various educational systems in OECD countries see Education in OECD countries: A compendium of statistical information (1993). 
Graph 2.5a

Employment shares of highly-skilled workers by occupational sectors in 1991

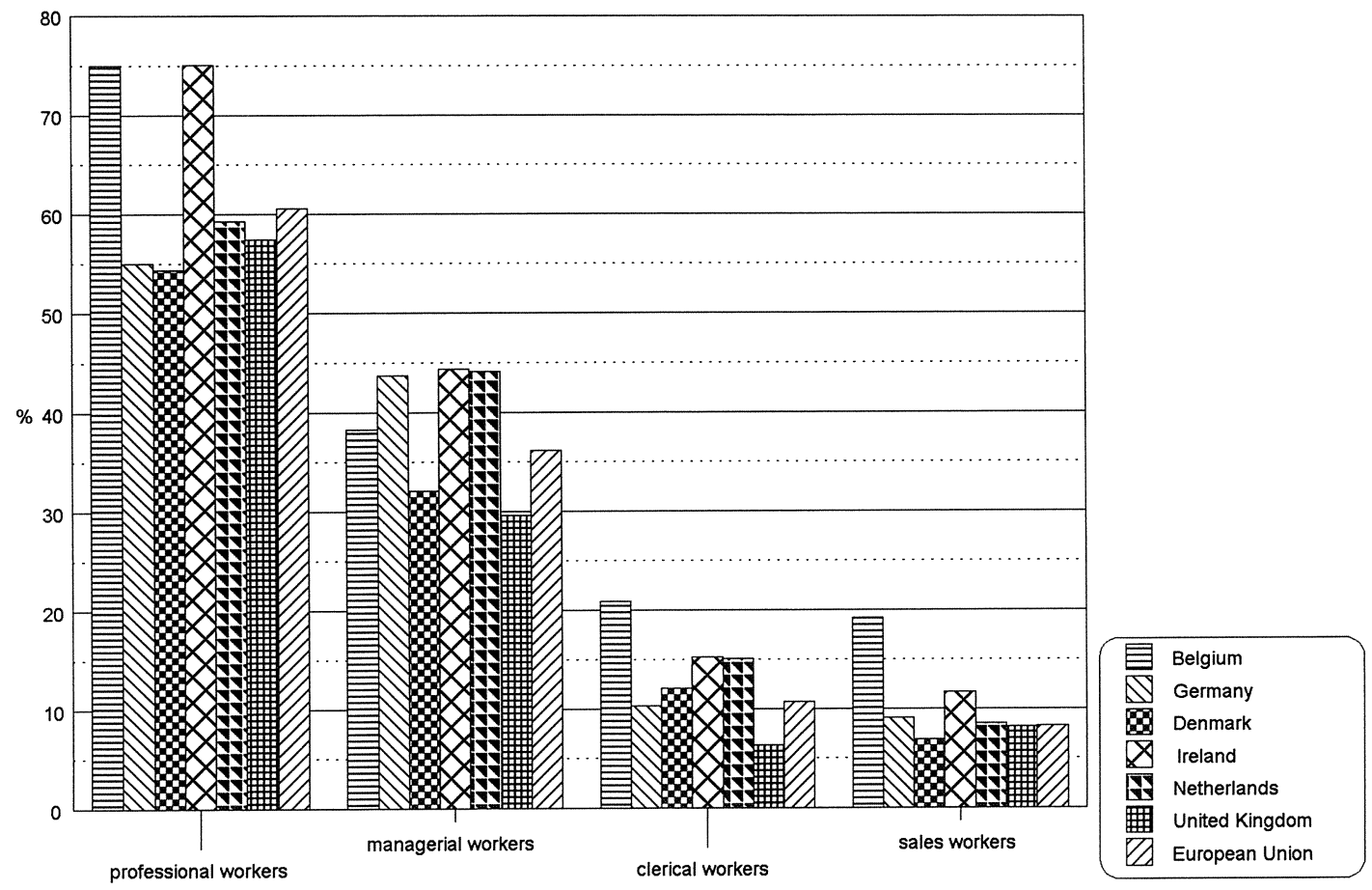

Source: EUROSTAT/ROA

Graph 2.5b

Employment shares of highly-skilled workers by occupational sectors in 1991

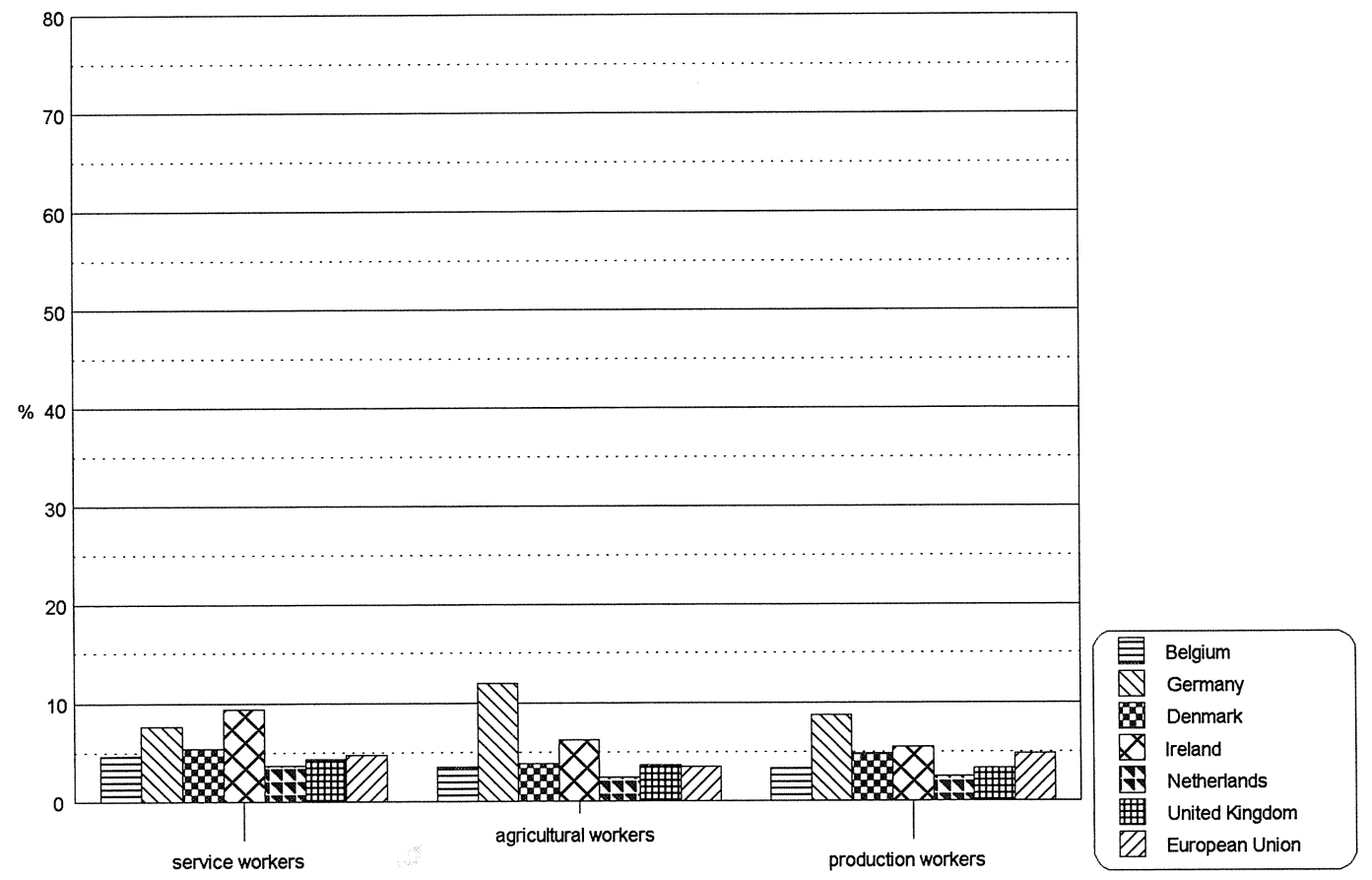

Source: EUROSTAT/ROA 
Graphs 2.4 and 2.5 seem to indicate that each occupational sector has a specific mixture of educational levels. The intermediate skilled workers are important in almost all occupational sectors, with averages from almost $35 \%$ in the sector of professional workers to almost $70 \%$ for clerical workers. The highlyskilled workers, however, only have relatively high employment shares in the occupational sectors of professional workers and managerial workers. The Dutch employment shares for intermediate skilled workers are clearly above the European Union level, but in general far behind Germany and Denmark. For the highly-skilled workers, Dutch levels are close to the European Union level. Overall, this seems to indicate that the Netherlands has a slightly above-average position, behind Germany and Denmark, but above the United Kingdom.

\section{Conclusion}

From the first part of this section it can be seen that the Netherlands, as a result of the relatively large number of low skilled and the relatively small number of intermediately skilled workers, can be placed at the lower end of the spectrum. However, when analyzing the EUROSTAT data on the educational level by occupation we see the Netherlands in the higher ranks. This can partly be explained by the absence of the United States, Sweden and Switzerland in the EUROSTAT data, and partly by the different definitions of educational levels which EUROSTAT and the OECD use. Overall, it can be concluded that the Netherlands has a relatively highly educated labour force in comparison to the old European Community Member States, but that in comparison to countries such as Sweden, Switzerland and the United States the Dutch educational level is much lower.

\subsection{Unemployment and labour market prospects}

Graph 2.6

Unemployment as a percentage of the workforce aged 25-64, 1989 and 1991

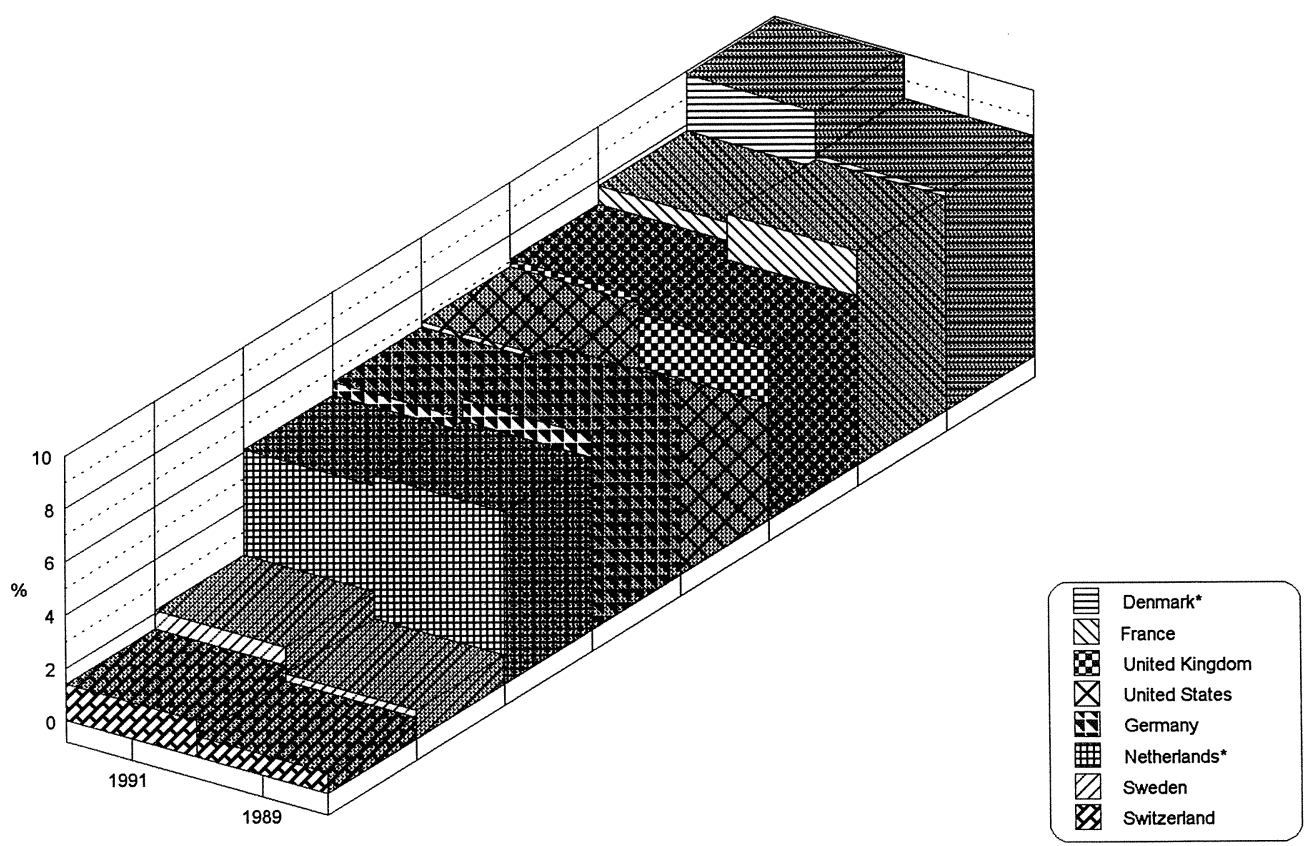

* The unemployment rate for the Netherlands for 1989 relates to 1990 data. The unemployment rate shown for Denmark in the 1989 row actually refers to 1988

Source: OECD 
Unemployment is also an indicator of a country's competitive position. A relatively high unemployment rate in a country indicates that this country's productive structure is less competitive. Changes in unemployment rates of course also reflect business cycle fluctuations.

Graph 2.6 shows total unemployment in percentages of the workforce for some OECD countries. Unemployment rates range from $9.9 \%$ in Denmark to $1.4 \%$ in Switzerland. Opposing trends can be observed in the various countries. In those which have traditionally had low unemployment (Sweden and Switzerland), a relatively large increase in unemployment can be observed, whereas France, Germany and the Netherlands show a small decrease in the total unemployment level.

Graphs 2.7 to 2.10 show the unemployment rates by level of education. These figures are very interesting as they can give an indication of the extent to which total unemployment is related to training mismatches between labour supply and demand.

We can see that, in all countries except for Switzerland, the unemployment levels for the low skilled lay well above total unemployment rates. The changes in the unemployment rates of the low skilled differ from country to country. In all countries, the unemployment levels of the intermediate skilled workforce were close to the average unemployment figures. For those with higher vocational education or university education, in all countries except Switzerland, the unemployment levels lay well below total unemployment.

In general terms, looking at the unemployment rates of the various educational levels, we can say that the unemployment rate is negatively related to the level of education in most countries. Only Switzerland has a higher unemployment rate for university educated workers than for less well-educated workers. On the other hand, this country, together with Sweden, still has remarkably low unemployment rates.

Graph 2.7

Unemployment in the low skilled (ISCED 2) workforce aged 25-64, 1989 and 1991

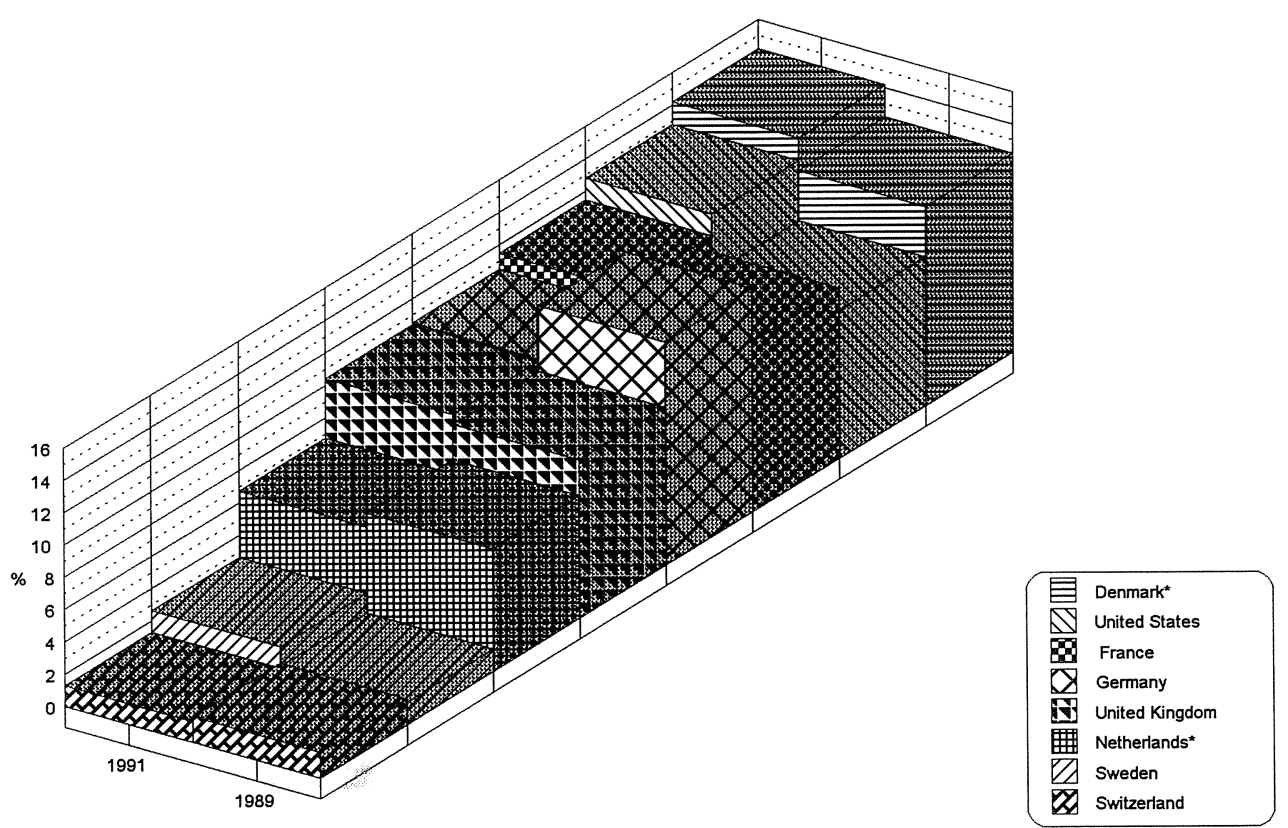

* The unemployment rate for the Netherlands for 1989 refers to 1990 data. The unemployment rate for Denmark shown in the 1989 row actually refers to 1988 .

Source: OECD 
Graph 2.8

Unemployment in the intermediate educated (ISCED 3) workforce aged 25-64, 1989 and 1991

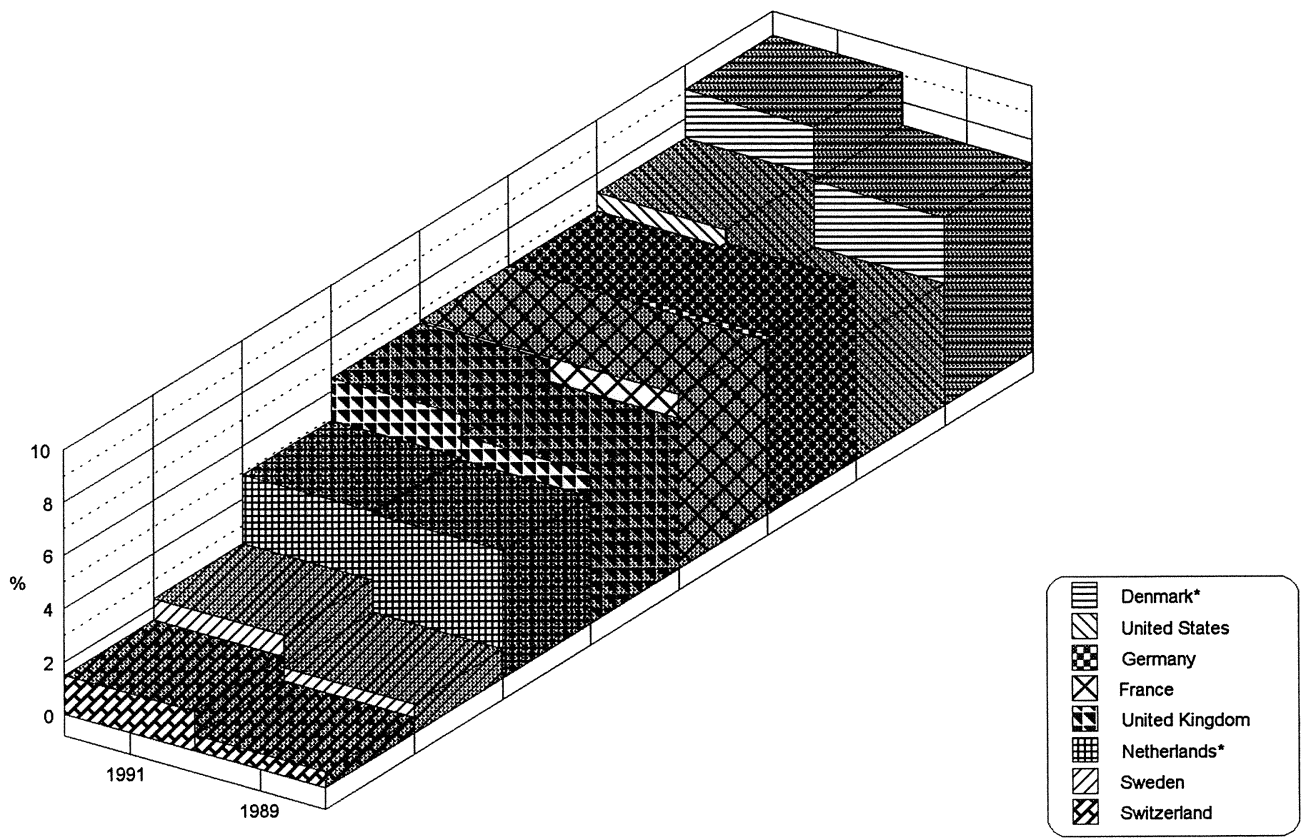

* The unemployment rate for the Netherlands for 1989 refers to 1990 data. The unemployment rate for Denmark shown in the 1989 row actually refers to 1988 .

Source: OECD

Graph 2.9

Unemployment in the workforce aged 25-64, with higher vocational education (ISCED 5), 1989 and 1991

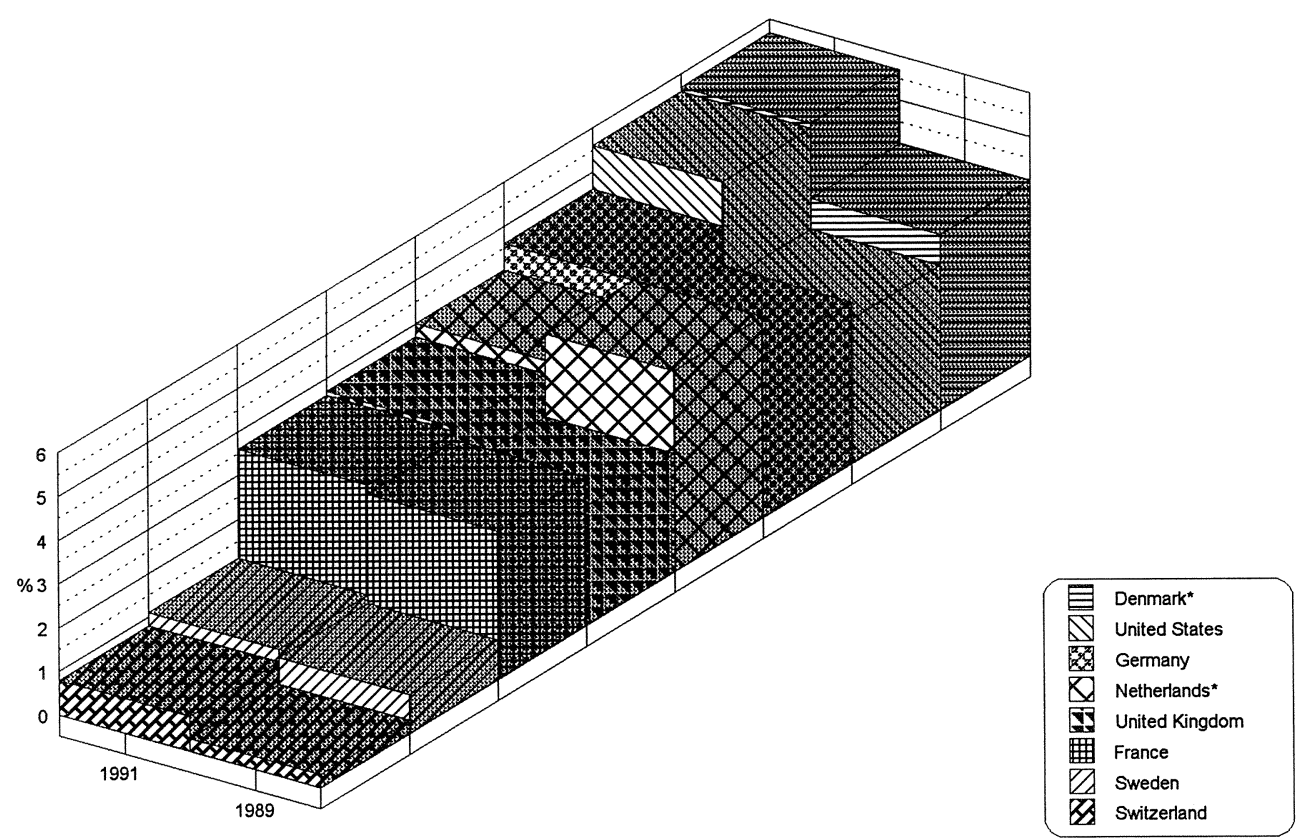

* The unemployment rate for the Netherlands for 1989 refers to 1990 data. The unemployment rate for Denmark shown in the 1989 row actually refers to 1988 .

Source: OECD 
Graph 2.10

Unemployment in the workforce aged 25-64, with university education (ISCED 6/7), 1989 and 1991

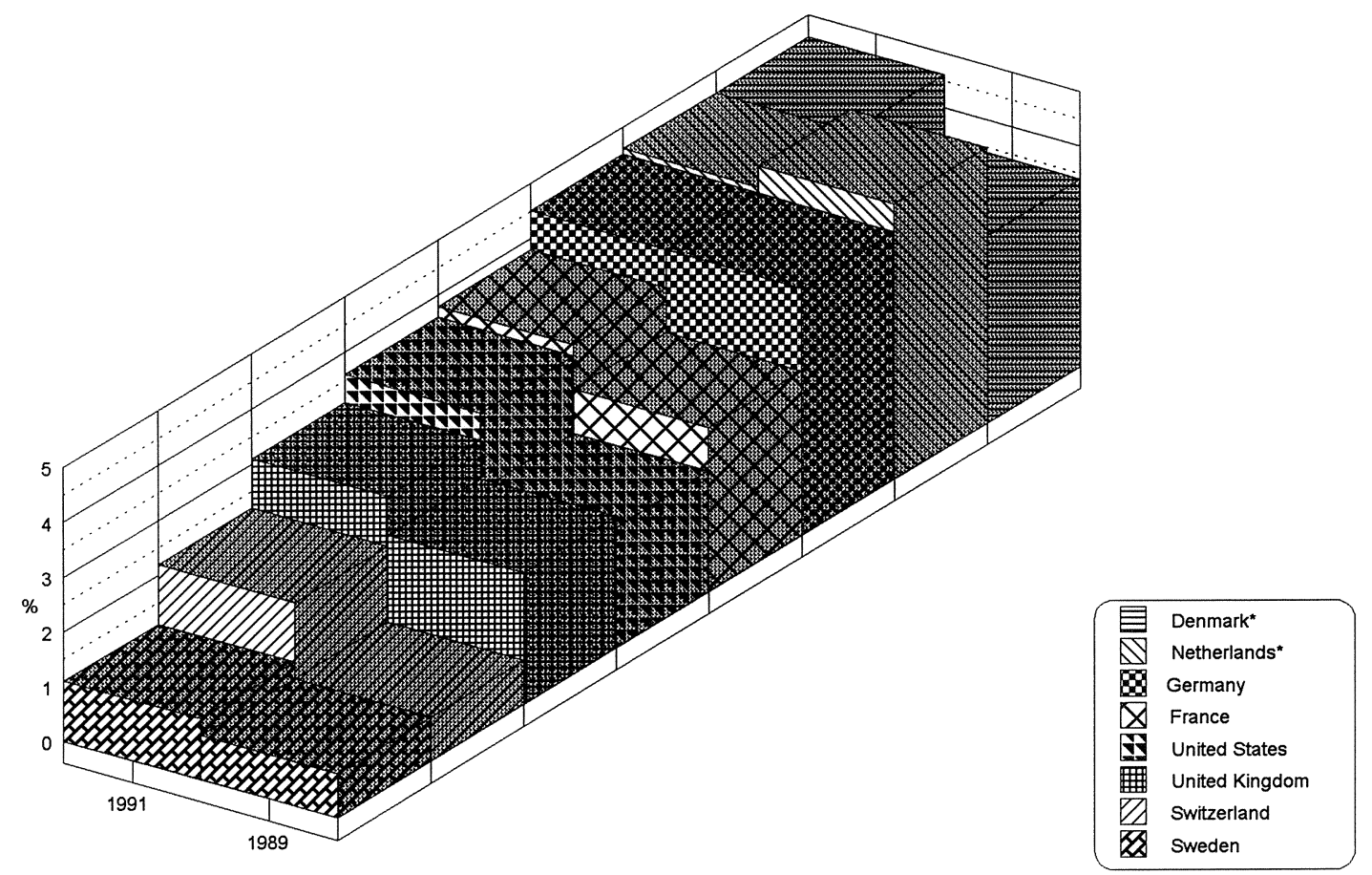

* The unemployment rate for the Netherlands for 1989 refers to 1990 data. The unemployment rate for Denmark shown in the 1989 row actually refers to 1988 .

Source: OECD

\section{Unemployment by educational category in the Netherlands}

There are also unemployment figures for the Netherlands in 1992, differentiated for broad educational categories (graph 2.11). Unfortunately only the total percentage and the percentage for those with only primary education are comparable with the figures of graph 2.12. However, it can be seen that total unemployment increased from $6.2 \%$ in 1992 to $7.5 \%$ in 1993 . This means that total unemployment increased by approximately 80,000 persons. The graph also shows that the unemployment rates for technically educated are by far the lowest of all educational categories. For the educational categories of technically educated can even be seen that the unemployment rates lie close to the frictional unemployment rate of $2.5 \%$ used by the Central Planning Bureau.

From graph 2.12 we can also see the unemployment rates of the population aged 15-24. The graph clearly shows that unemployment rates for young people lie far above total unemployment rates, for all educational sectors. Young people thus suffer most from the worsening labour market in the Netherlands. On the other hand, there is now a relatively large pool of highly trained cheap unemployed workers, who can easily be made use of when the economy starts to recover. Again, it can be seen that the vocationally educated youngsters suffer less from the high unemployment rates. 
Graph 2.11

Unemployed workforce by educational category, 1992

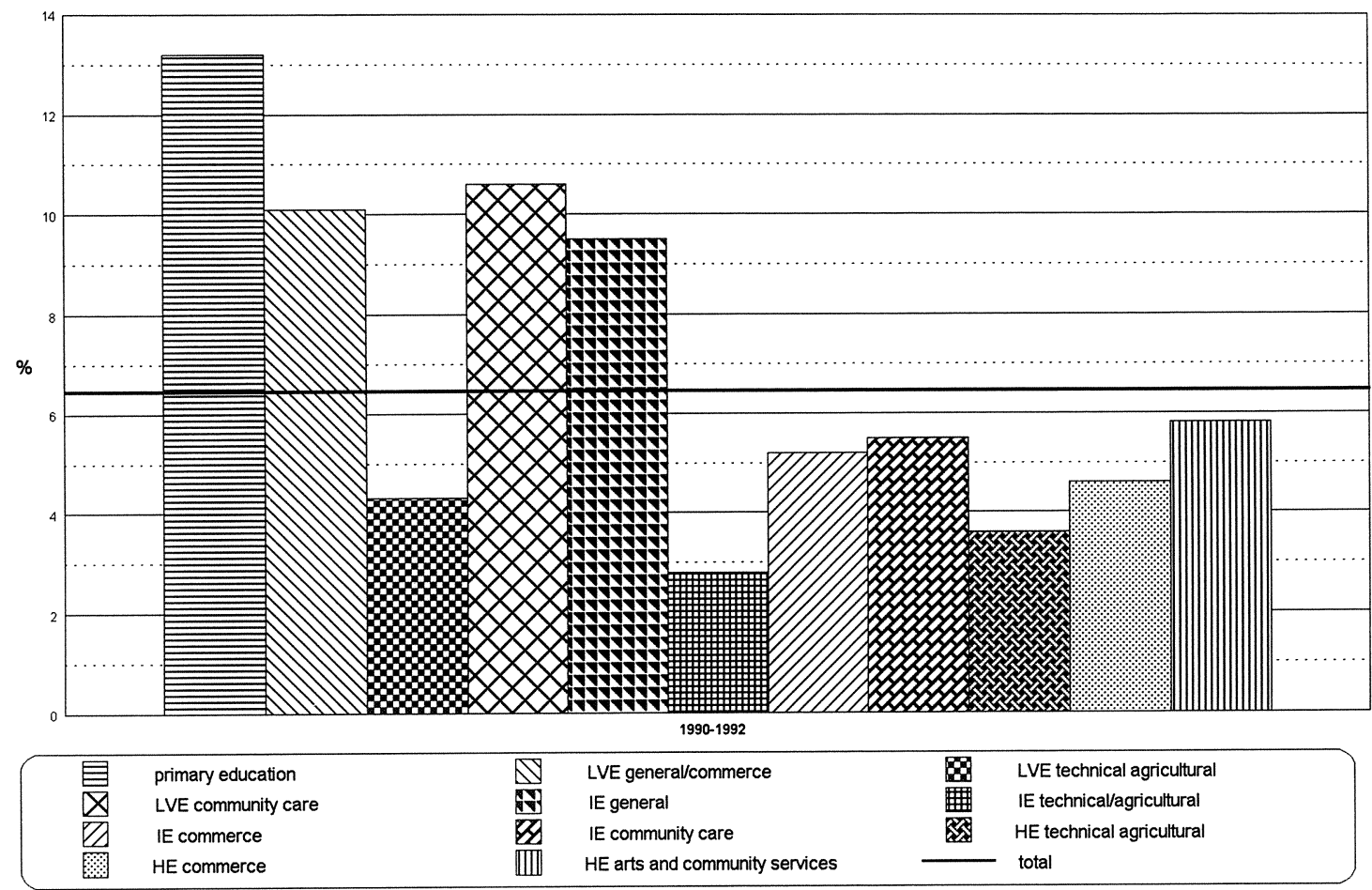

Source: Central Employment Board (1993)

Graph 2.12a

Unemployment by educational sector in 1993, for the population aged 15-24

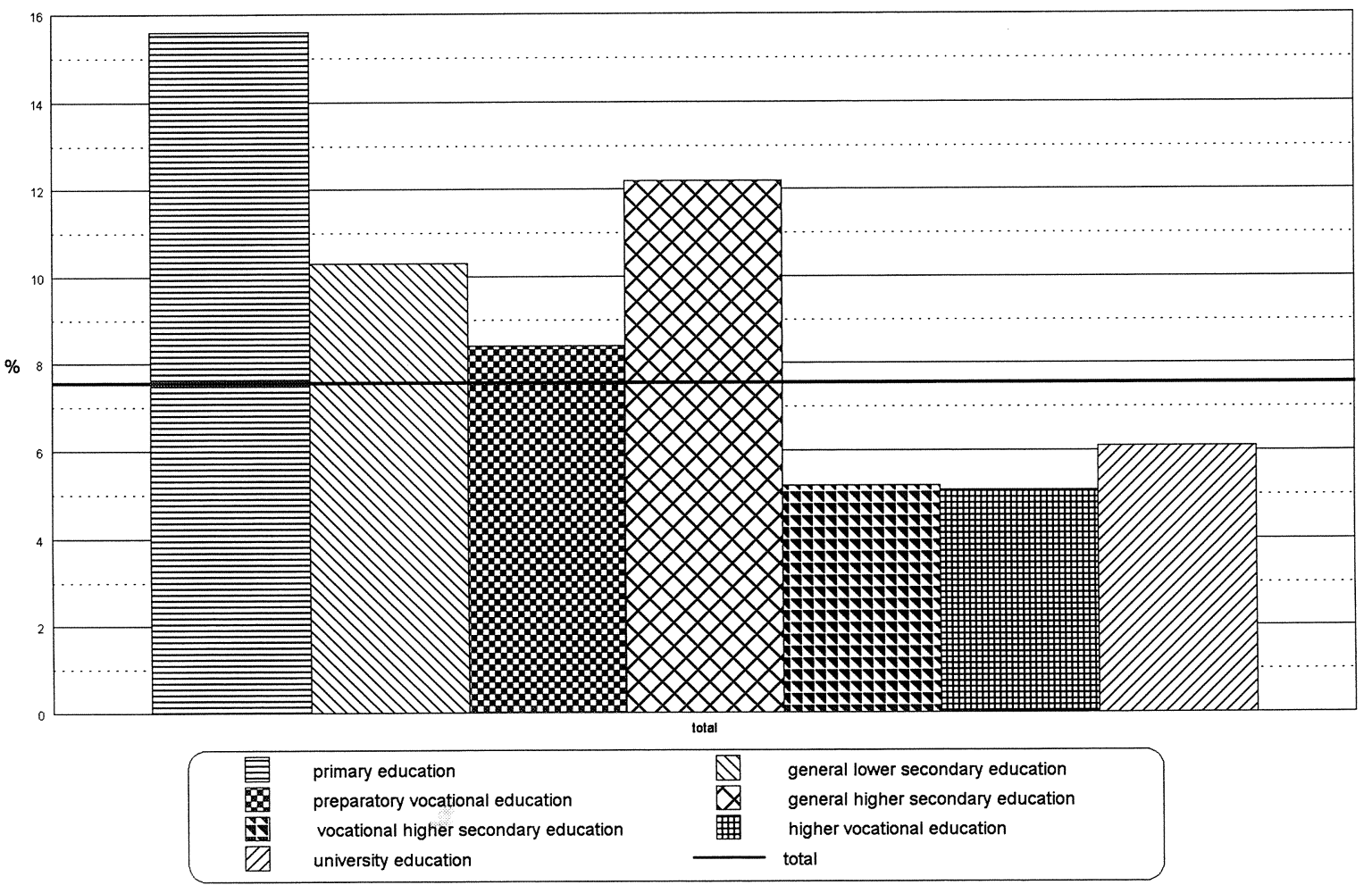

Source: CBS 


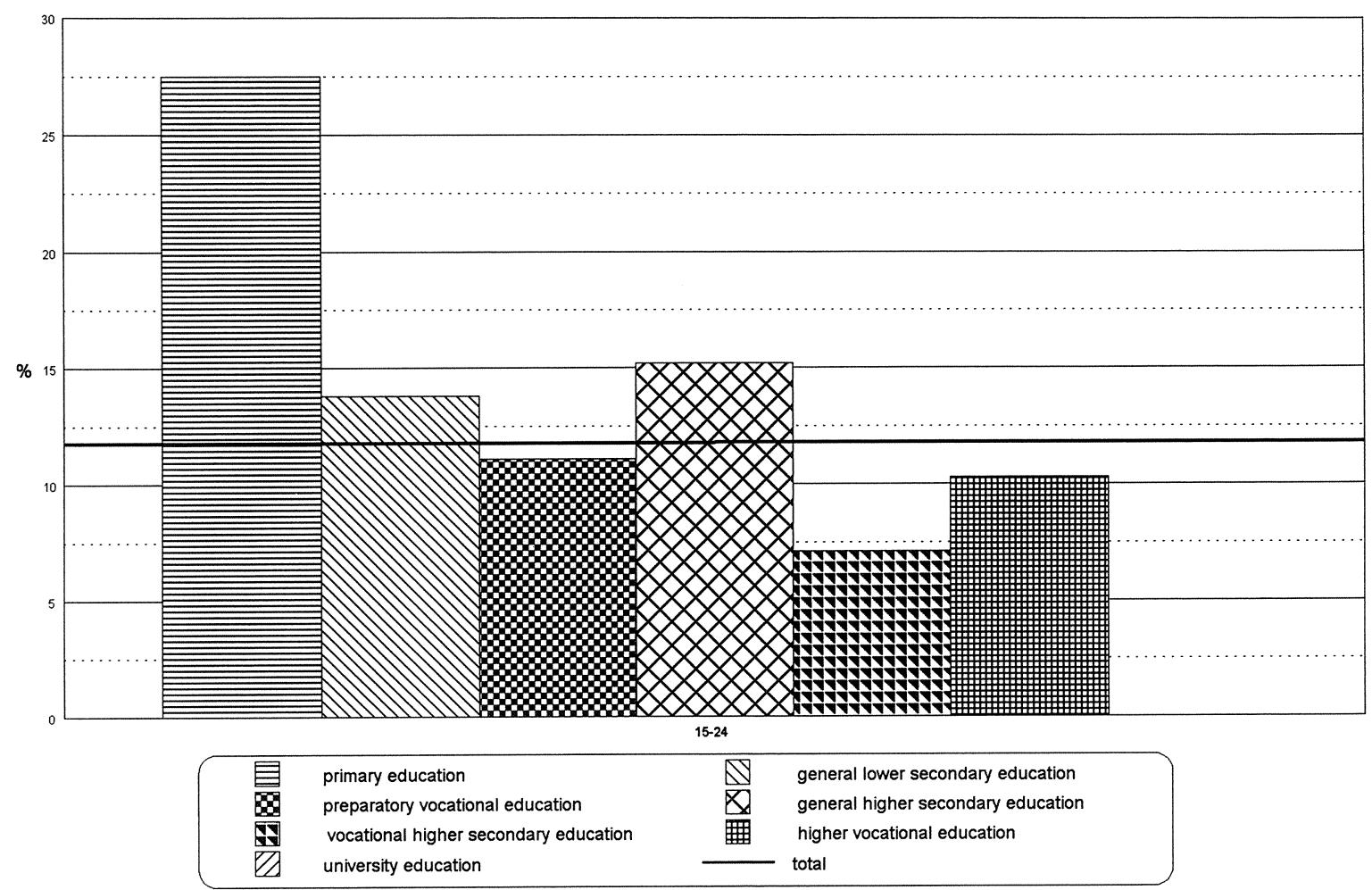

Source: CBS

Projections of changes in the size and occupational composition of the labour force

The Employment Outlook of July, 1994, provides some projections differentiated by main occupational groups, for Australia, Canada, Ireland, Japan, the United Kingdom and the United States ${ }^{5}$ (graphs 2.13 to 2.18$)$.

As we have seen in the period 1980 - 1990, in the years to come the greatest increase in employment levels can be expected in the occupational sector of professional workers, in all countries. The occupational sector of agricultural workers shows a relative decline for all countries, and in some countries even an absolute decline. With the exception of the United Kingdom, all countries listed will have a relatively large growth in employment in their respective projection periods. The projections for Australia show an employment growth of $17.9 \%$, for Canada $11.2 \%$, for Ireland $4.9 \%$, for the United Kingdom $0.1 \%$, for the United States $21.8 \%$ and for Japan $5.9 \%$. In almost all countries the largest employment growth is realized in the occupational sector of professional workers. Also the managerial workers show in general large employment growth. This means that the occupational sectors with the highest average educational level are responsible for a large part of the employment growth.

5. The OECD has made the data as comparable as possible. 
Graph 2.13

Projected employment composition for Australia, in percentages of total employment and in absolute numbers $(x 1,000)$
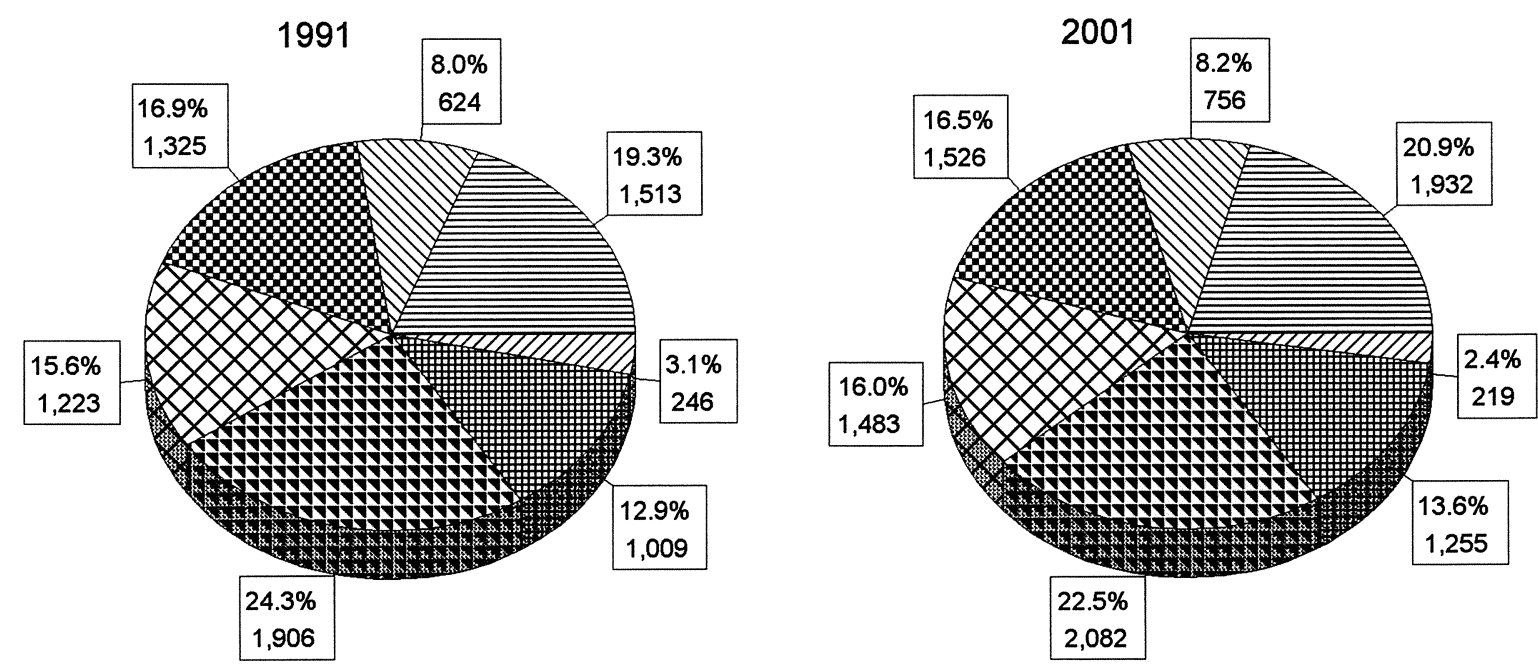

ISCO'68

$\begin{array}{llll}\text { professional workers } & \text { clerical workers } \\ \text { crafts workers } & \text { agricultural workers } & \text { managerial workers } & \text { pales workers }\end{array}$

Source: OECD

Graph 2.14

Projected employment composition for Canada, in percentages of total employment and in absolute numbers $(x 1,000)$
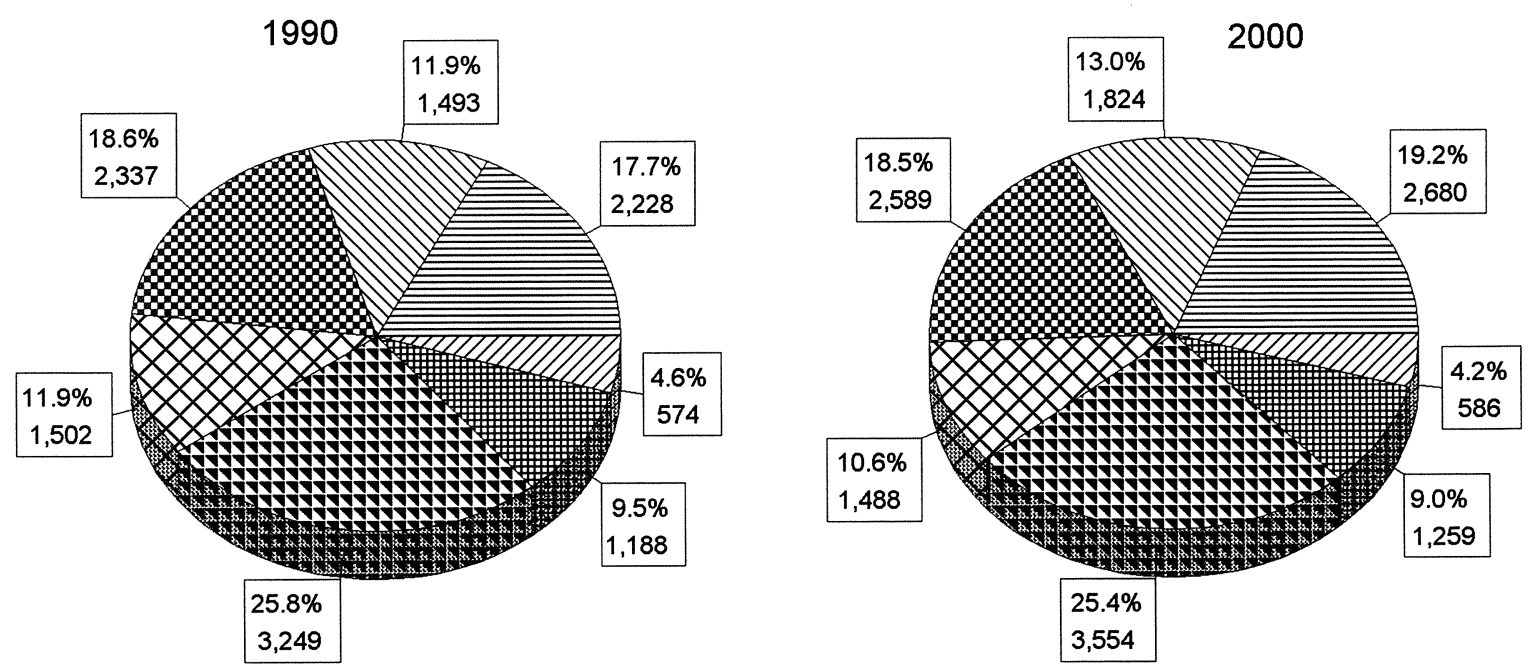

\section{ISCO'68}

professional workers
crafts workers

agricultural workers

$\begin{array}{lll}\text { managerial workers } & 8 \text { clerical workers } \\ \text { production and service workers } & \text { sales workers }\end{array}$

Source: OECD 
Graph 2.15

Projected employment composition for Ireland, in percentages of total employment and in absolute numbers $(x 1,000)$
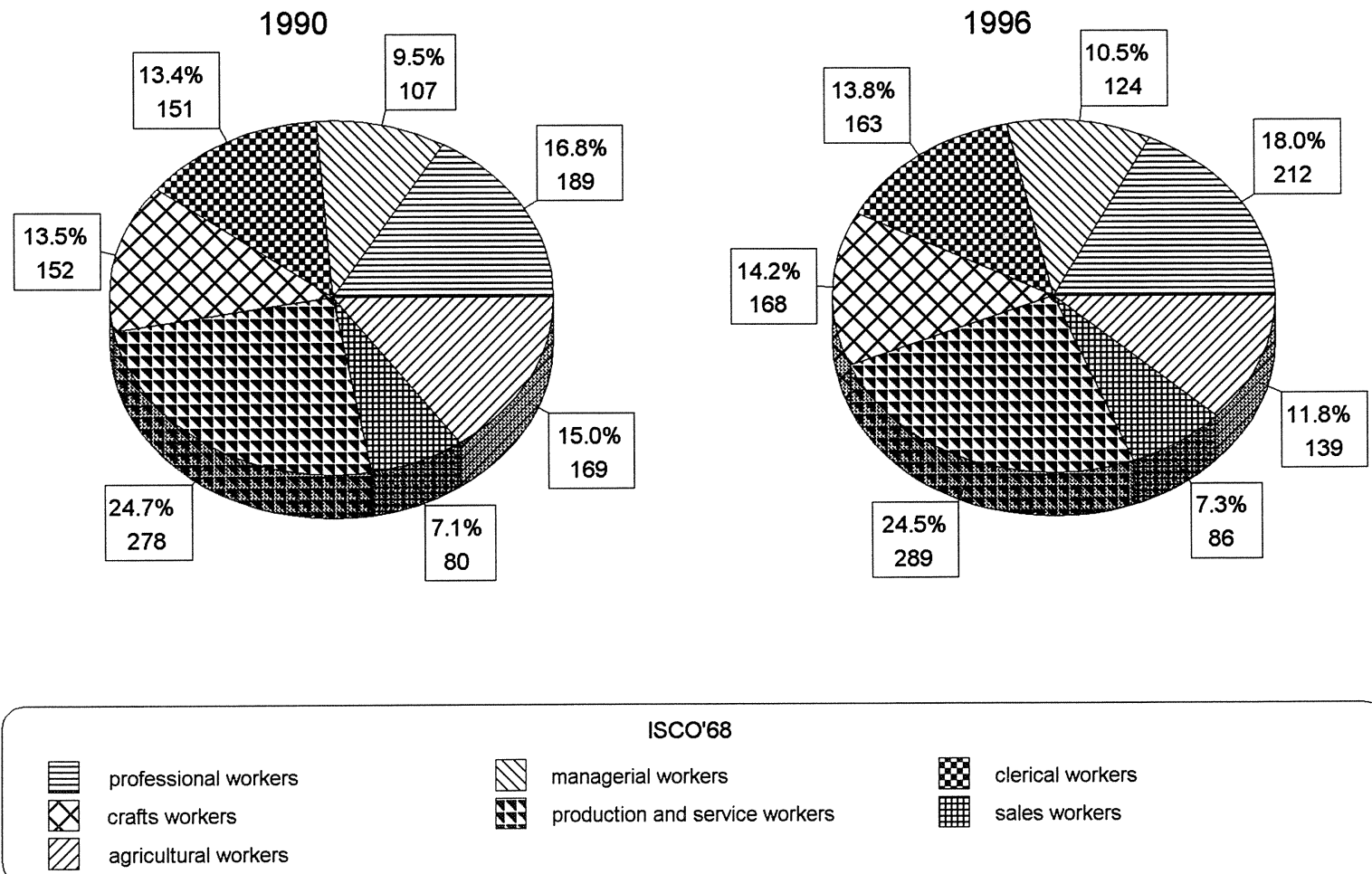

Source: OECD

Graph 2.16

Projected employment composition for the United Kingdom, in percentages of total employment and in absolute numbers ( $\mathrm{x}$ $1,000)$
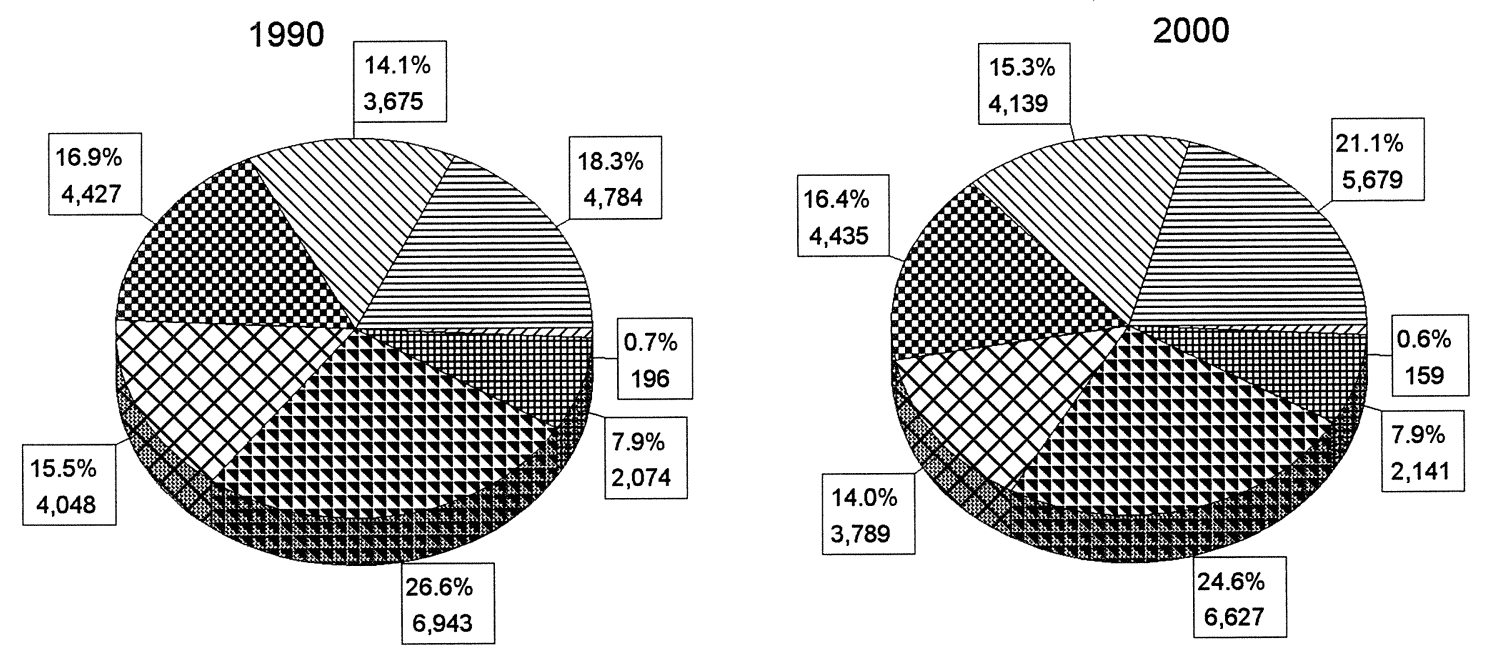

ISCO'68

professional workers
crafts workers
$\nabla \Delta$ agricultural workers

managerial workers

88 clerical workers

Ny production and service workers

sales workers

Source: OECD 
Graph 2.17

Projected employment composition for the United States, in percentages of total employment and in absolute numbers ( $X$ $1,000)$
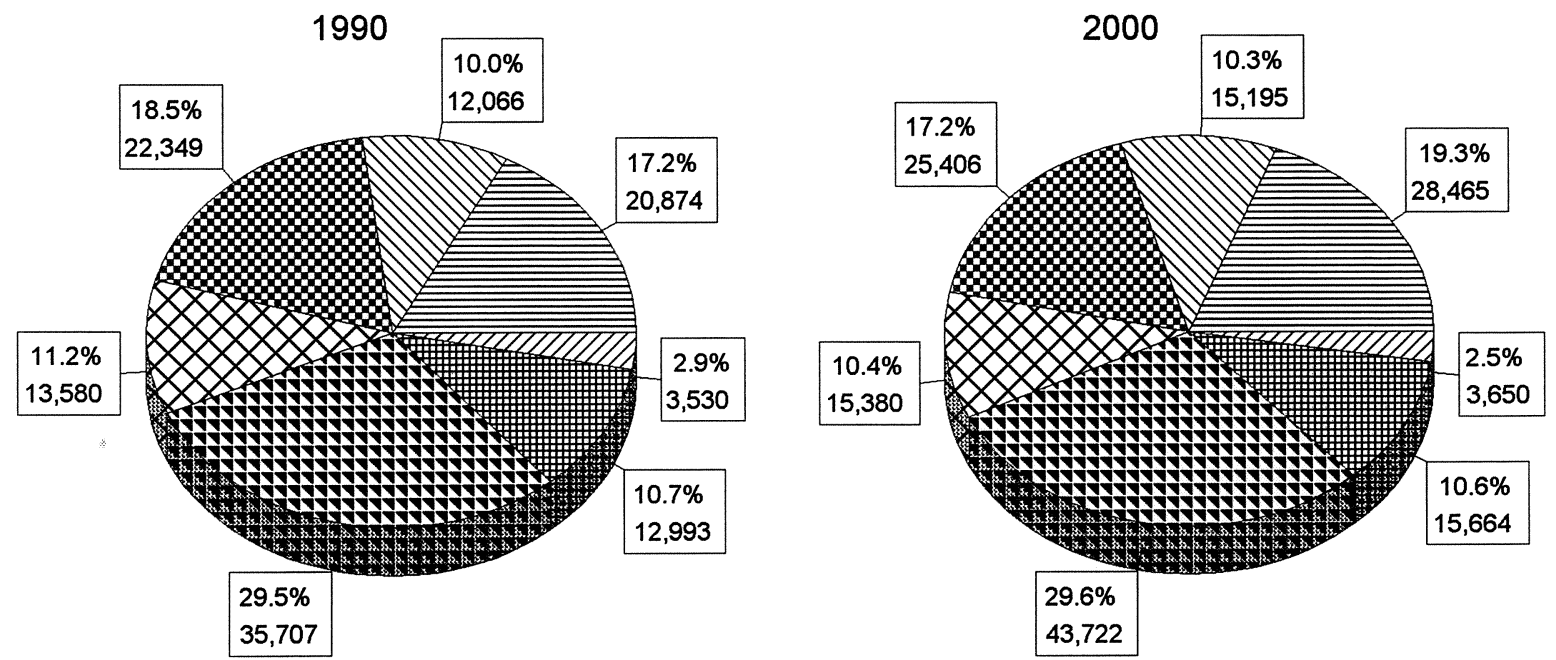

ISCO'68

$\begin{array}{llll}\text { professional workers } & & \text { clerical workers } \\ \text { crafts workers } & \text { managerial workers } & \text { sales workers }\end{array}$

Source: OECD

Graph 2.18

Projected employment composition for Japan, in percentages of total employment and in absolute numbers $(x 1,000)$
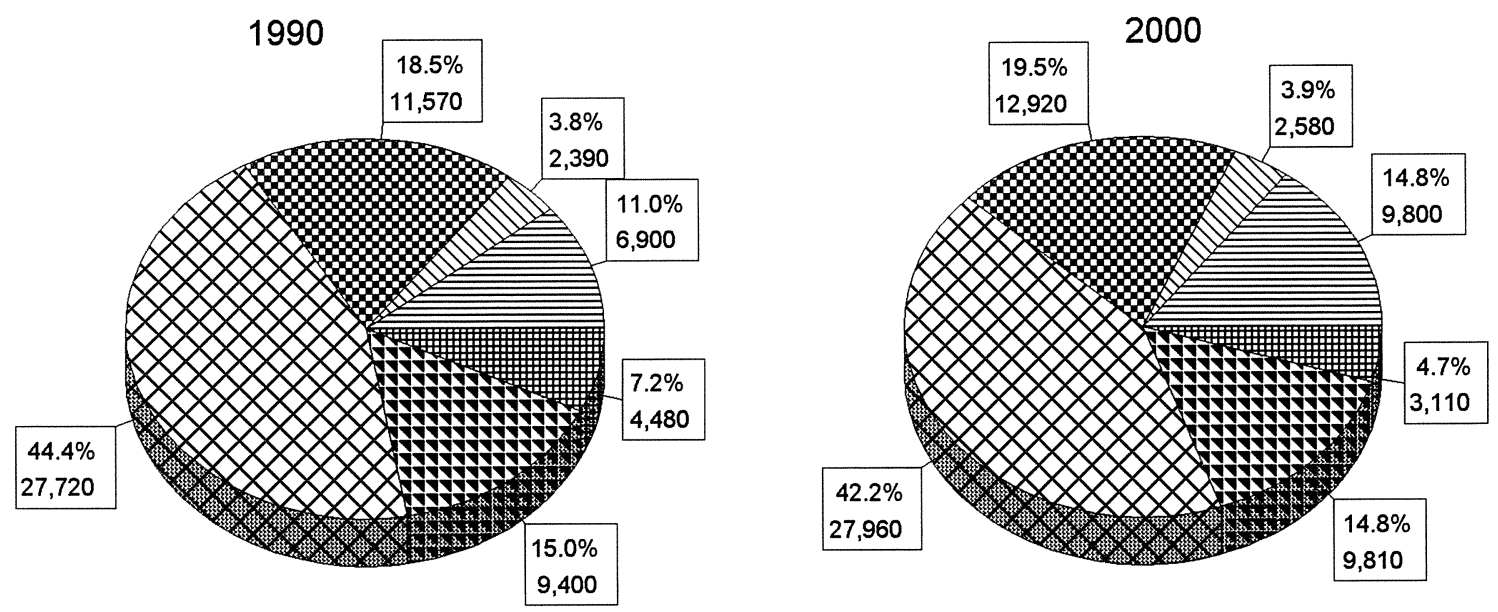

\begin{tabular}{|llll|}
\hline & ISCO'68 & \\
professional workers & & managerial workers \\
clerical workers & crafts, production and services workers \\
sales workers & agricultural workers \\
\hline
\end{tabular}

Source: OECD 
The labour market and labour market prospects by type of education and occupation in the Netherlands

ROA produces a biannual report for the Netherlands entitled The labour market by education and occupation. The latest report was published in 1993. The report provides a picture of the current labour market position, and projections for the labour market up to 1998. The results in this section are based on ROA's own occupational classification, which means that they cannot be compared to results based on the ISCO'68.

Table 2.19 shows the distribution of employment over the various occupational sectors. The second largest occupational sector is that of 'technical and industrial occupations', employing almost 1.5 million people, or $27 \%$ of the Dutch working population. However, graph 2.20 shows that the 'technical and industrial occupations' also had the second lowest average employment growth in the period 1988-1992. Whereas the total annual employment increase in these years amounted to $1.6 \%$, the 'technical and industrial occupations' only grew by $0.4 \%$ per year. For the period 1993-1998, an even lower annual employment growth, of $0.3 \%$, is predicted. However, this expected low employment growth for technical workers still means an increase of approximately 18,000 full-time equivalents, whereas the high growth of the employment rate of cultural workers only represents an increase of approximately 5,500 full-time equivalents.

Graph 2.19

Employment by occupational sector in the Netherlands in 1992

1992

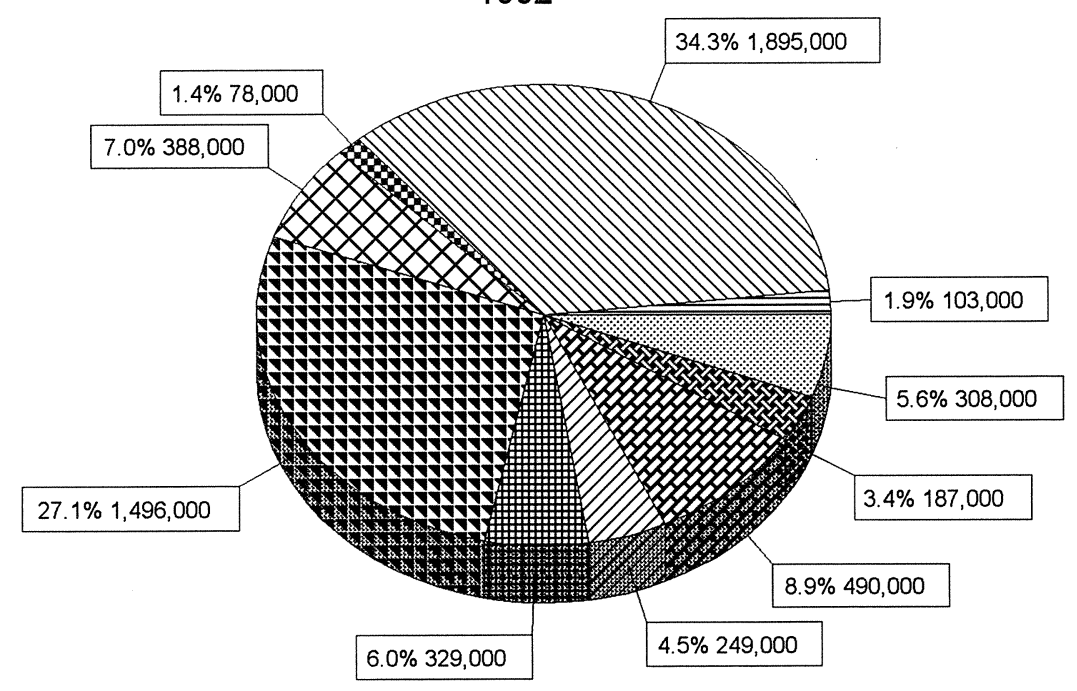

\begin{tabular}{|lllll}
\hline technical workers & commercial workers & cultural workers & medical workers \\
socio-cultural workers & transport workers & agricultural workers & educational workers
\end{tabular}

Source: CBS/ROA 
Graph 2.20a

Changes in Dutch employment, by occupational sectors, 1988-1992 (average annual growth)

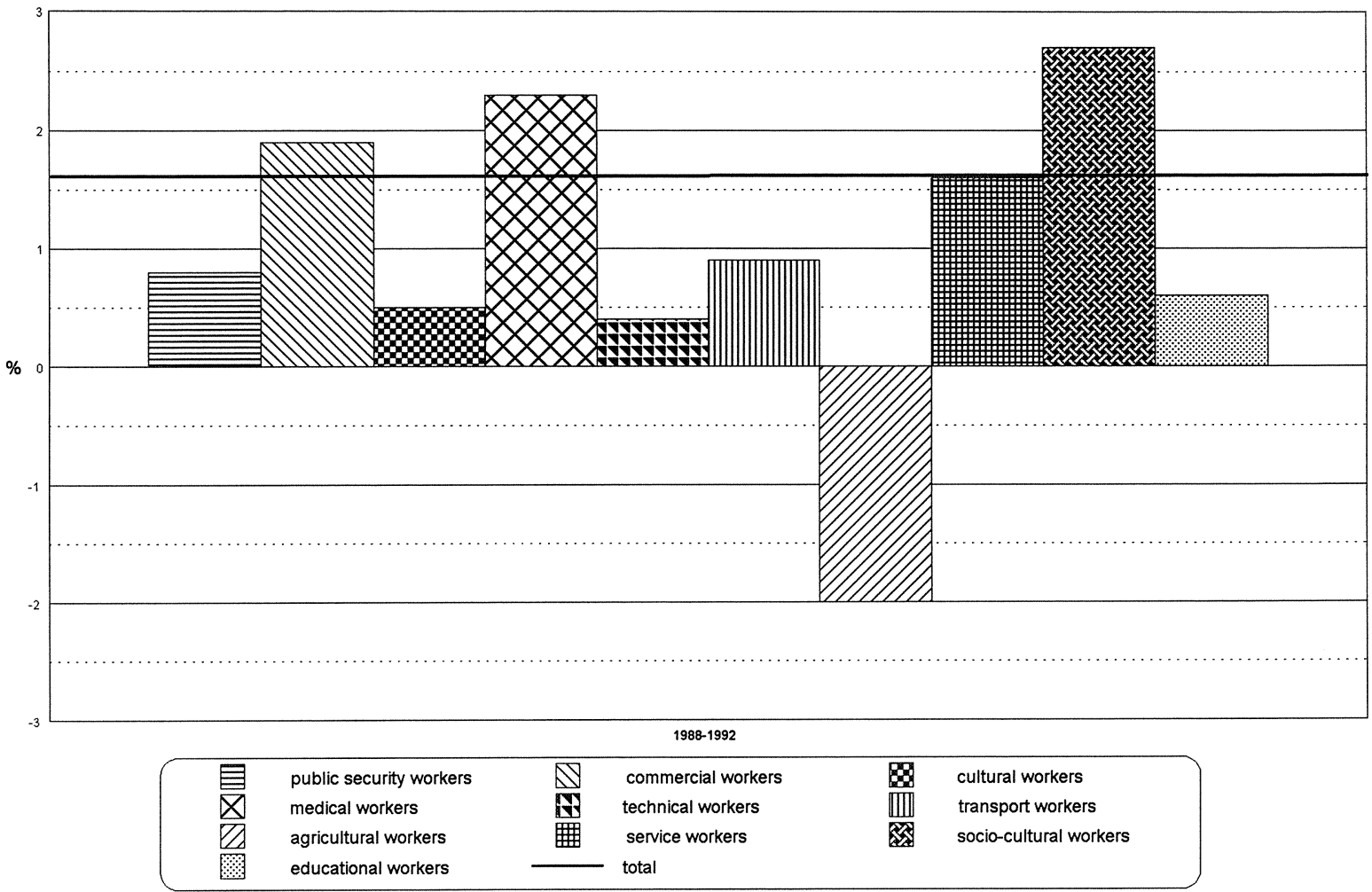

Source: CBS/ROA

Graph $2.20 b$

Changes in Dutch employment, by occupational sectors, projections for 1993-1998 (average annual growth)

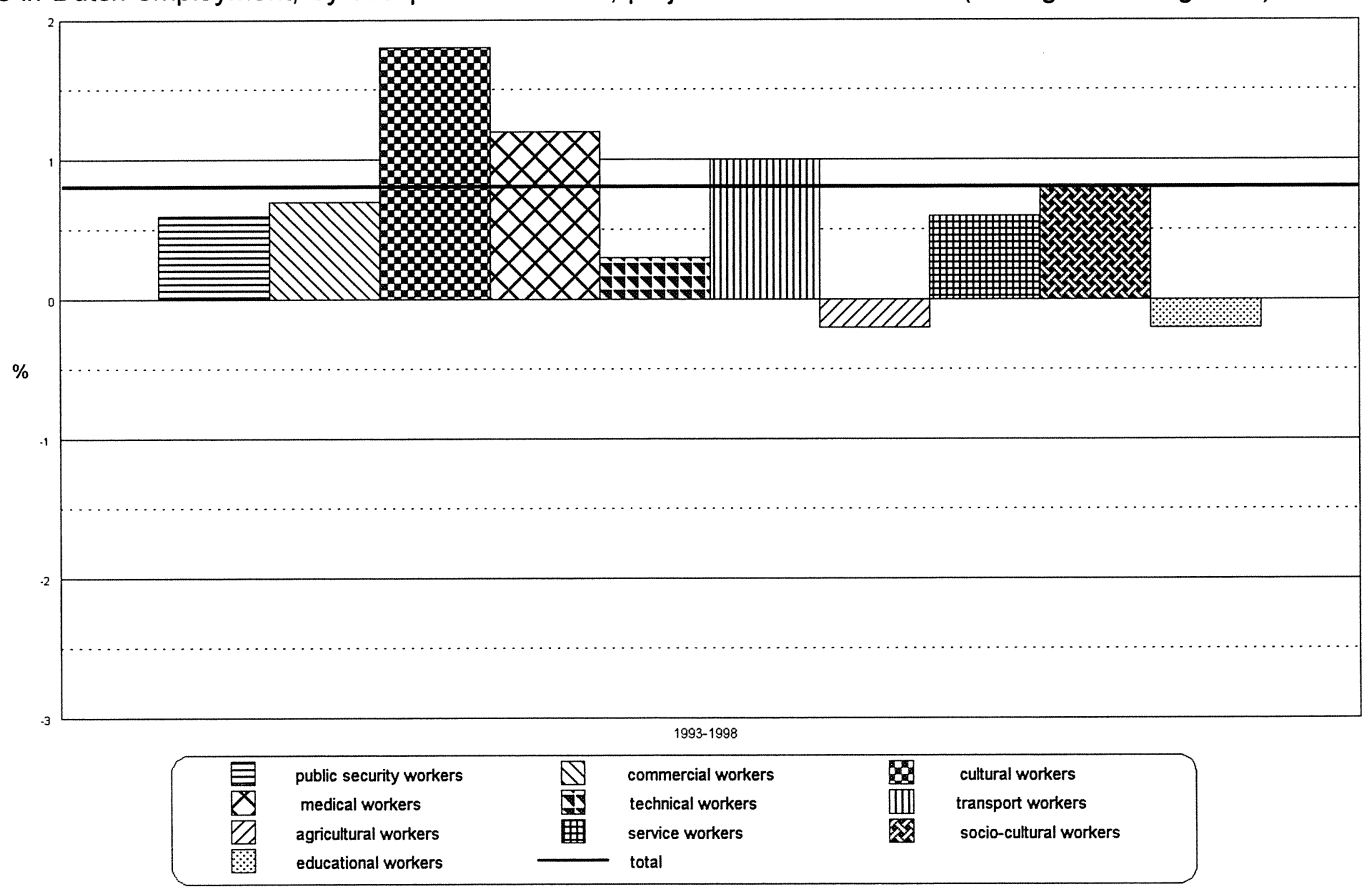

Source: CBS/ROA 
Graph 2.21 gives an overview of the workforce as in graph 2.19, but now differentiated by categories of education. It can be seen that the technical/agricultural educational categories account for almost 1.8 million people or $31 \%$ of the workforce. Workers educated at the intermediate level have the highest employment share, with $42 \%$, while those with only primary education, with lower level education and with higher level education have employment shares of $10 \%, 24 \%$, and $23 \%$, respectively.

Graph 2.21

Employment by educational category in the Netherlands in 1992

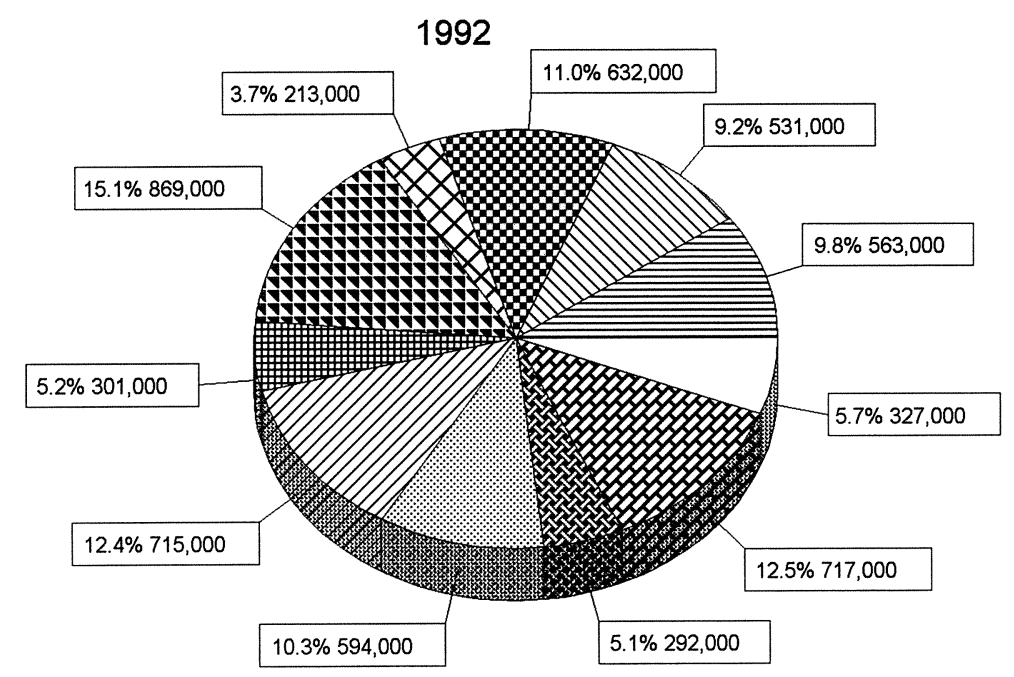

\begin{tabular}{|lllll|}
\hline primary education & LVE* general/commerce & LVE technical agricultural \\
LVE community care & IE*t technical/agricultural & IE general \\
IE commerce & IE community care & HE & \\
\hline HE arts and community services & $\square$ & HE commerce & \\
\hline
\end{tabular}

* LVE $=$ Lower Vocational Education (ISCED 2 level)

** $\mathrm{IE}=$ Intermediate Education (ISCED 3 level)

$* * * \mathrm{HE}=$ Higher Education (ISCED 5/6/7 level)

Source: CBS/ROA 
Graph 2.22a

Change in employment by educational category, 1990-1992 (average annual growth)

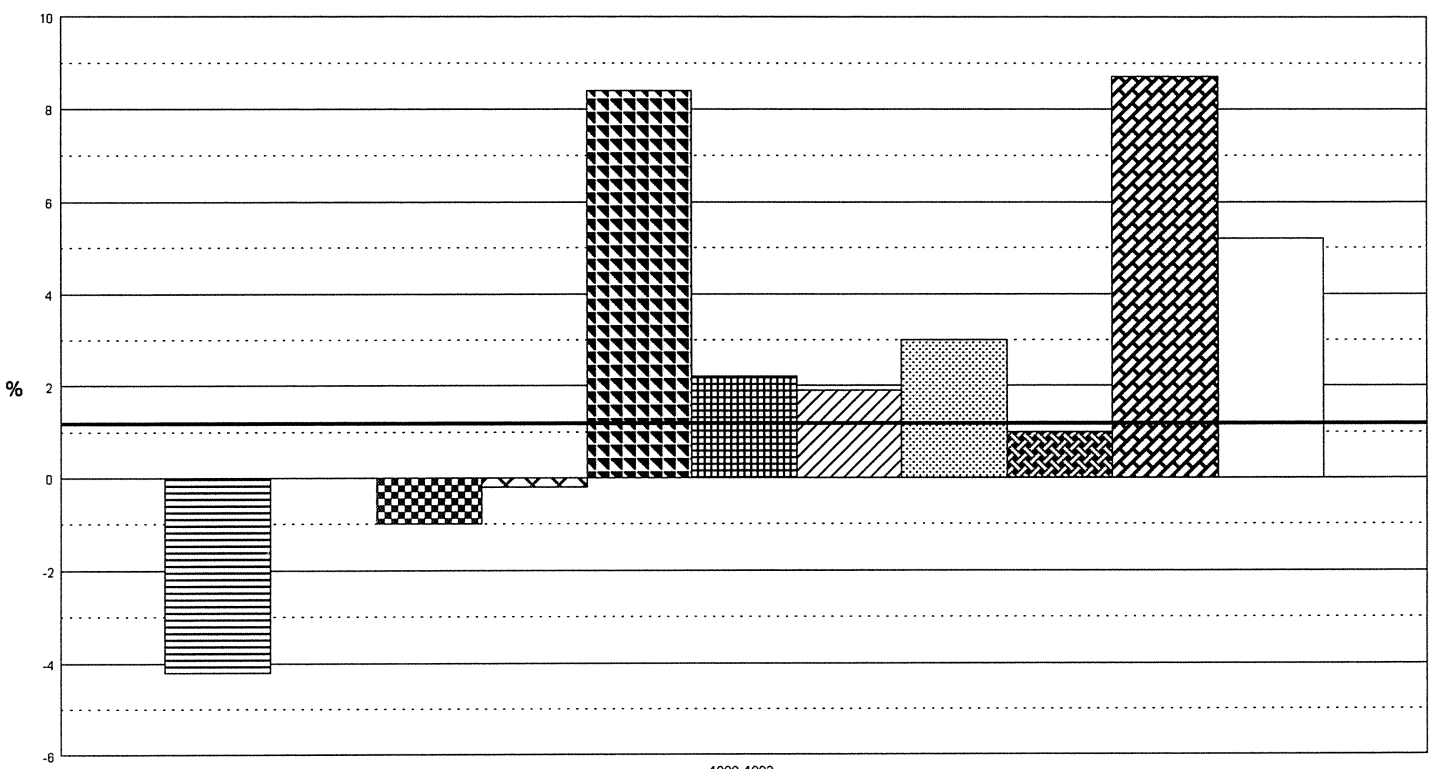

1990-1992

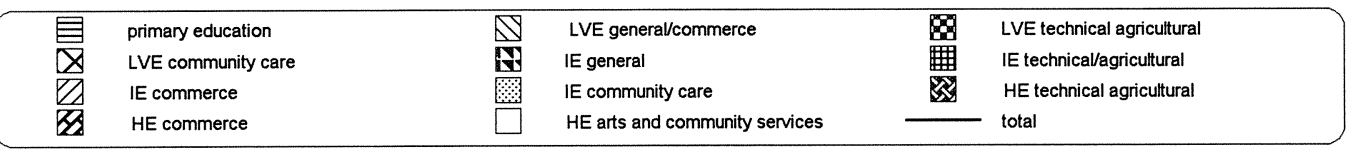

Source: CBS/ROA

Graph 2.22b

Change in employment by educational category, and projections for 1993-1998 (average annual growth)

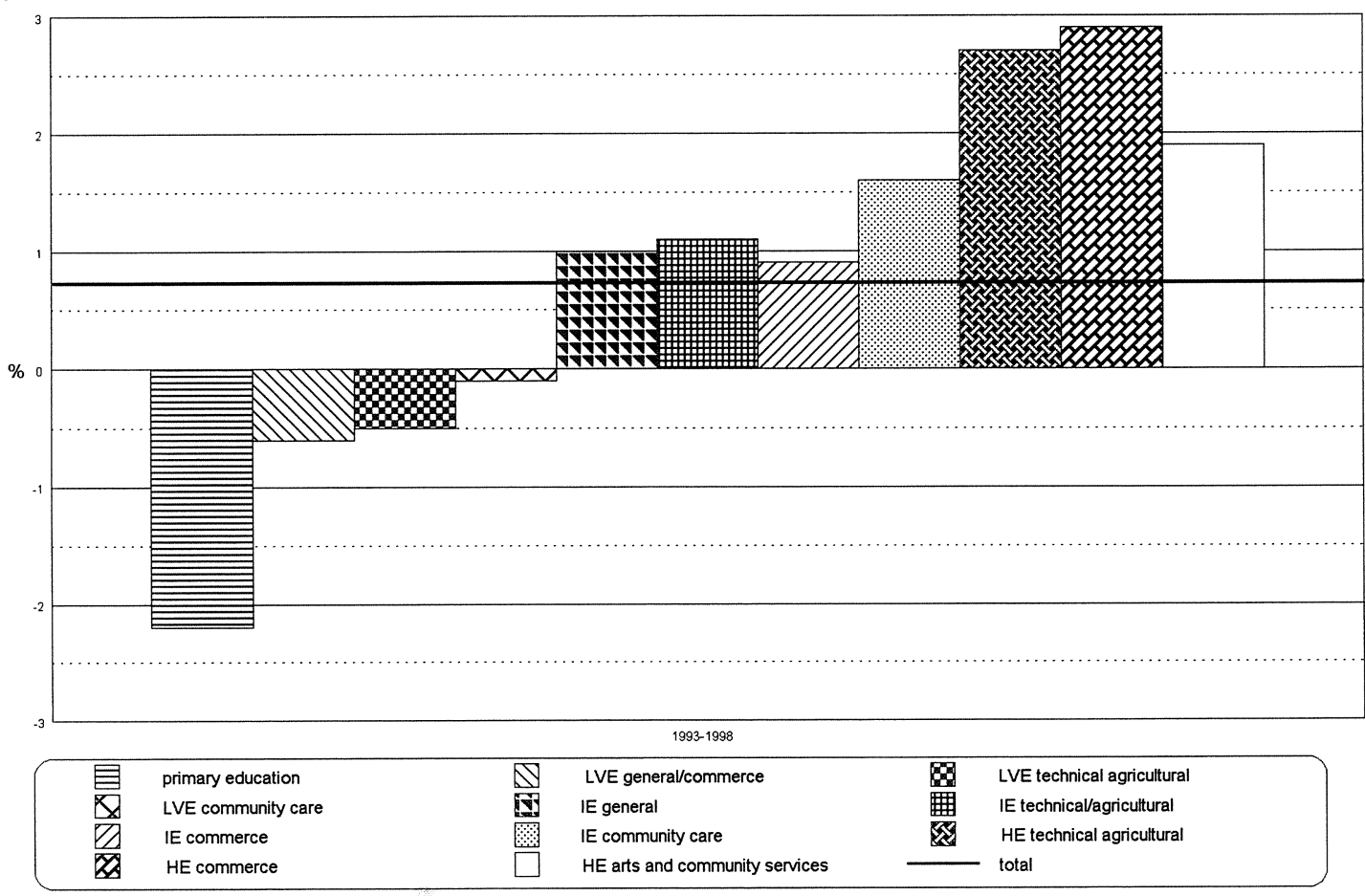

Source: CBS/ROA 


\section{Conclusion}

With regard to total unemployment, the Netherlands has the third lowest unemployment rate, after Sweden and Switzerland, of the countries in our sample. However, by examining the various educational levels, it can be seen that the relatively low Dutch unemployment rate has mainly been caused by relatively low unemployment rates at the lower and intermediate levels. For those with a university education, the Netherlands, together with Denmark, leads the unemployment rates, although the rate at this educational level is still roughly half the total unemployment rate.

Unemployment rates by educational category in the Netherlands show that unemployment is relatively low among workers with a technical education. In 1992, unemployment for this category was close to the level of frictional unemployment. The average unemployment rates using Dutch data, shown in graph 2.11, is in line with the average based on OECD data in graph 2.6. since we can see in graph 2.11 that unemployment rates for the higher technical types of education are all below the Dutch national average, and graph 2.10 shows that unemployment for those with higher education in the Netherlands is among the highest in the OECD countries, it would be reasonable to suppose that unemployment rates among those with higher education in the other countries in the OECD must be much lower than in the Netherlands. Unemployment rates for 1993 show that unemployment among young people was much higher than for the total population. Again the position for those with vocational education was better than for those with general education.

With regard to the projections of changes in the size and occupational composition of the labour force, it can be seen that, although the figures for the various countries are not fully comparable, the occupational sectors of professional workers and managerial workers exhibit the largest employment growth. As could be seen from section 2.2, these two occupational sectors also have the highest educational level. This indicates that many of the new jobs that will be created will be for those with higher education.

Graph 2.22 showed that employment levels only rose in the period 1990-1992 in the educational categories at intermediate or higher level. It is remarkable that workers with a technical/agricultural background had one of the lowest annual rates of employment growth. This gets even more peculiar when the unemployment figures, presented in graph 2.11 , are taken into account, where people with a technical/agricultural education have the lowest unemployment rates. The Central Planning Bureau (1992) uses a frictional unemployment rate of $2.5 \% .^{6}$ This means that unemployment for those with intermediate or higher technical education is very close to the level of frictional unemployment, which indicates a relative shortage of technically educated workers. In the period 1993-1998, only the technically educated workers are expected to do much better than in the 1990-1992 period. This again seems to indicate that there frictions may arise in the labour market for technically educated personnel in the near future.

\subsection{Flexibility of the labour force}

In this section the flexibility of the labour force is measured. Two 'risk-indicators' have been developed for the purpose. These indicators measure the adaptability of the workforce in the face of technological developments, so far as this is related to the age structure of the population or the flows of schoolleavers entering the labour market. The first indicator is the ratio of young people (15-24 years) to older

6. There has been a discussion in the Netherlands about the level of frictional unemployment. Some analyses use percentages as high as $6 \%$. However, we have chosen to use the frictional unemployment rate used by the CPB. 
workers (50-65 age group). The rationale for this 'population adaptability indicator' is that one might expect young people to adapt more easily to new technologies. Young people can be more easily trained, and they represent the most recent cohorts coming from initial education. For the 50-65 age group, the risk of skill obsolescence is rather high. Moreover, human capital investments for these workers, to adapt to new technologies, are often limited due to the relatively short period that they will remain active.

The second indicator is a measure of the skill level flexibility of the population. The indicator measures the proportion of school-leavers in a certain educational sector in relation to the share of the same educational sector in the population of 25-64 years old. This indicator shows the direction of future shifts in the skill structure of the labour force. Unfortunately it can, at the moment, only be calculated for the Netherlands.

\section{Population adaptability indicator}

The first indicator measures the adaptability of the total population. This is done by dividing the share of the 15-24 age group in the total population by the share of the 50-64 age group in the total population. A value of 100 indicates that the shares of young people and older people are equal. A value above 100 indicates more young people than older people, and a value below 100 indicates that the proportion of older people is higher than that of young peoples. In the latter case the economy will be more vulnerable to skill obsolescence due to technological developments.

Graph 2.23

Adaptability of the population in the face of technological developments, 1980-1991

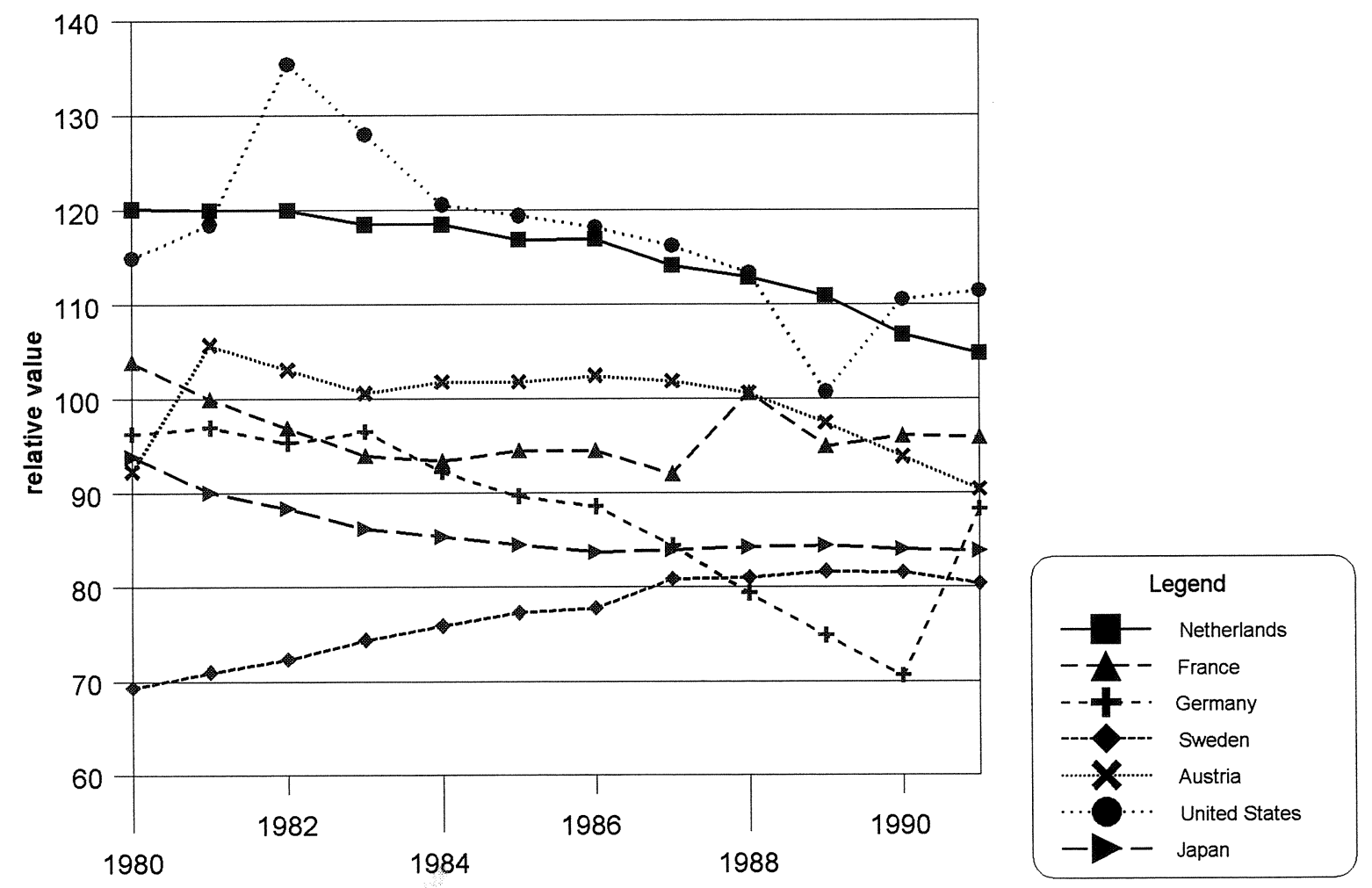

Source: ILO/OECD/ROA 
Graph 2.23 shows the changes in this adaptability indicator for several countries in the period 19801991. It can be seen that most countries show a decreasing trend. This indicates that the population is becoming less flexible. Only the United States and the Netherlands have values above 100, showing a relatively large proportion of young people. However, most countries show decreasing trends, which means that the number of youngsters is relatively decreasing. Improving the flexibility of the workforce by employing highly skilled youngsters will thus become more difficult. An increase in the flexibility thus has to established more and more by continuing vocational education.

\section{Skill level flexibility indicator of the Dutch population}

The skill level flexibility of the Dutch population shows the proportion of school-leavers having a particular educational level in relation to the share of that educational level in the population aged 15-64. A value of 100 indicates that the proportion of school-leavers with a certain educational level is as high as the share of that educational level in the population. A value above 100 means that the proportion of school-leavers is higher, which means that the skill category's share in the total population in increasing. If the educational level in question is one of the higher skill categories, this indicates an upgrading tendency. However, for the lower skill levels a value above 100 is an indicator of downgrading tendencies.

Graph 2.24

Skill level flexibility indicator for the Dutch population of 15-64, $1990-2010$

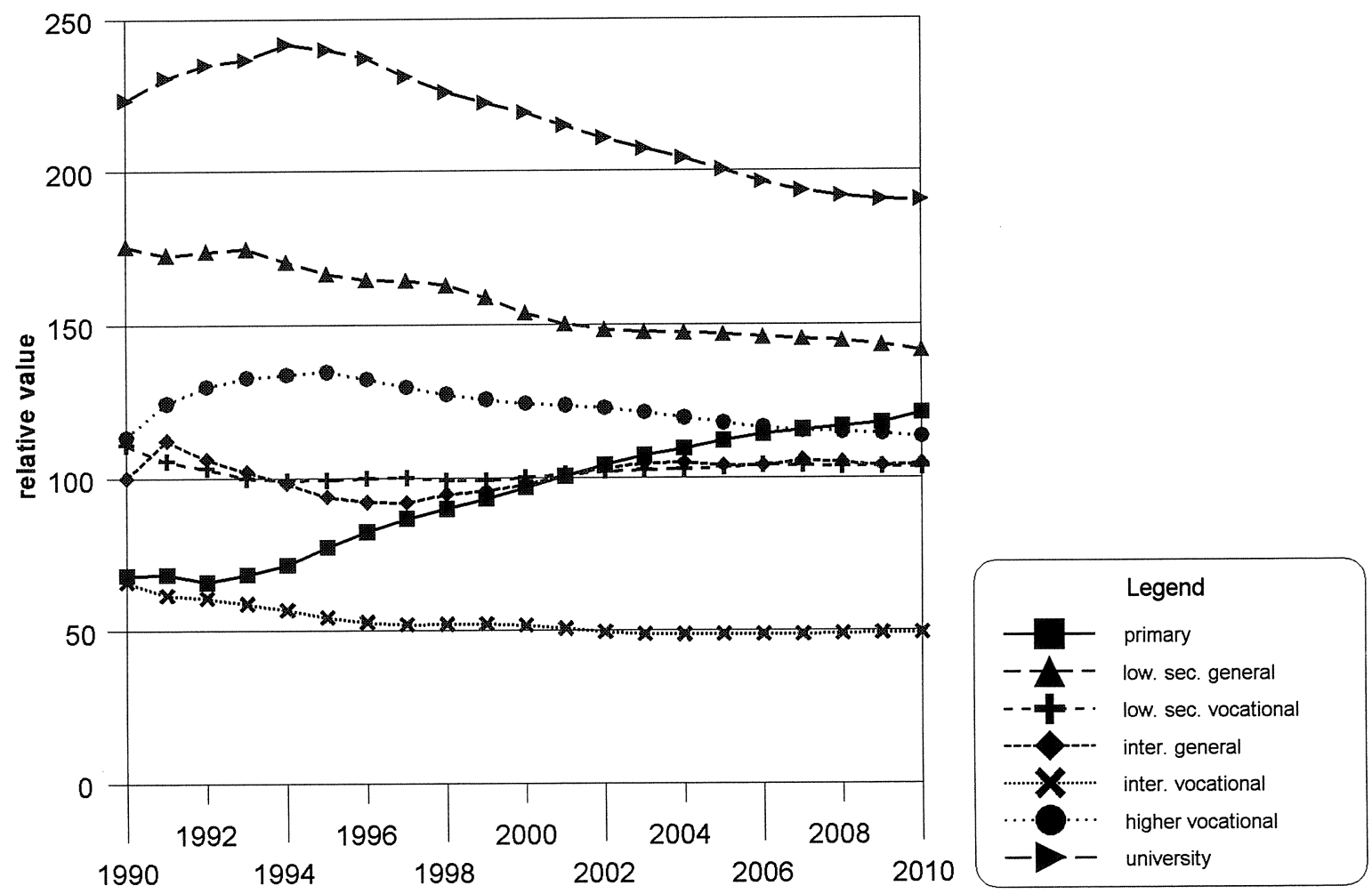

Source: Referentieraming 1993/ROA

Graph 2.24 shows that the number of people with university education will rise enormously in the next decade, although from 1995 onwards the relative proportion will start to decrease. The overall tendency is one of upgrading of the labour force, as part of a rising average educational level. The same tendency can be observed for lower general secondary education. It can also be seen that the share of 
preparatory secondary vocational education will remain stable. What is worrying, however, is the large increase in the share of people with primary education only, indicating that the number of drop-outs is rising, and the continuing low share of students in intermediate vocational education, which in the longer term may lead to a shortage of these workers.

\section{Conclusion}

This section analyzed the flexibility of the labour force. It could be seen that in most countries the proportion of young people is decreasing. This decrease indicates that continuous vocational training is becoming more important for countries which want to increase the flexibility of the labour force.

There is an overall upgrading trend in the skill level flexibility of the Dutch population, but two worrying developments can be observed. The proportion of students dropping out is increasing, while the proportion of students taking intermediate vocational education remains low. This indicates that there may be a shortage of these workers in the long term. 


\section{Initial education}

\subsection{Introduction}

In this chapter, some trends in initial education will be analyzed. Initial education is the basis for a welltrained and flexible labour force. A good match between the curricula used in initial education and the labour market is a necessary condition for easy adaption to the skill requirements posed by technological developments. For example, the introduction of computers in schools is crucially important, in order to provide pupils with the necessary basic skills required in an information society. Of course, initial education still also plays a major role in human capital formation processes in general.

In this chapter we will examine the relative importance of initial education in some OECD countries. Section 3.2 will analyze public expenditure on education, and will also consider whether there is convergence or divergence on this measure between the various countries. Convergence/divergence analysis, which will be used often in the following sections, shows whether the differences between countries are becoming smaller (convergence) or larger (divergence). ${ }^{7}$

Section 3.3 will analyze the trends in higher education, and section 3.4 will focus on vocational education. Finally, section 3.5 will deal with unemployment and the labour market prospects of Dutch school-leavers.

\subsection{Public expenditure}

Public expenditure on education as a percentage of real Gross Domestic Product (GDP) can be seen as a measure of the national support for education. However, one must be careful in interpreting this ratio as some countries' expenditures for tertiary education include substantial public subsidies for student living expenses, whereas other countries' expenditures do not (OECD, 1993). ${ }^{8}$

Graph 3.1 shows real public expenditure as a percentage of real GDP. ${ }^{9}$ The graph shows that public expenditure on education is generally decreasing over time. The decrease in the Netherlands was the highest of all countries since 1976. The Netherlands is now one of a large group of countries spending about $5.5 \%$ of GDP on education. Only Sweden spends more than $6 \%$ of real GDP on education.

The results of the convergence/divergence analysis, presented in graph 3.2, show that the differences between the various countries remained rather stable between 1975 and 1991, although there has been a diverging trend between 1975 and 1980 and a converging trend from 1981 to 1989 , followed by a

7. The analysis is based on the following formula:

$$
C l=\frac{\sum_{k 1}^{n}\left(x_{j}-\bar{x}\right)^{2}}{(n-1)}
$$

$\mathrm{Cl}=$ Convergence (Divergence) Indicator

$\mathrm{X}=$ Variable

$\mathrm{j}=$ Country

As can be seen, this formula is a well-known variance formula. If the value of this indicator decreases in the course of time, this can be interpreted as a convergence, whereas in the case of divergence, the variance will increase.

8. The figures for the Netherlands certainly include student living allowances, and so to a lesser degree do the figures for France, Germany and the United Kingdom.

9. For Japan and the Netherlands, the figure is based on real public and private educational expenditure. 
diverging trend again from 1989 onwards.

Graph 3.3 shows public expenditure per student. It can be seen that the expenditure per student has increased strongly since 1986, in all countries. The expenditure per student in the Netherlands is roughly in the middle of the range in this graph. This means that, in absolute terms, public investment per student is less than in some other highly developed countries. These results contrast with the rankings for public expenditure on education as a proportion of GDP, in which the Netherlands held the second position behind Sweden. The graph also shows that the United States spends the most per student, and about $35 \%$ more than in the Netherlands.

Graph 3.4 shows that there is a clear diverging trend in the public expenditure per student for the countries listed in graph 3.3. From this graph it can be concluded that the national support for investment in initial education is increasing in the high-spending countries, and decreasing in the lower spending countries. In graph 3.1, this divergence can be seen in the rapidly increasing gap between the high-spending United States and low-spending Japan.

\section{Graph 3.1}

Real public expenditure on education as a percentage of real GDP, $1976-1991$

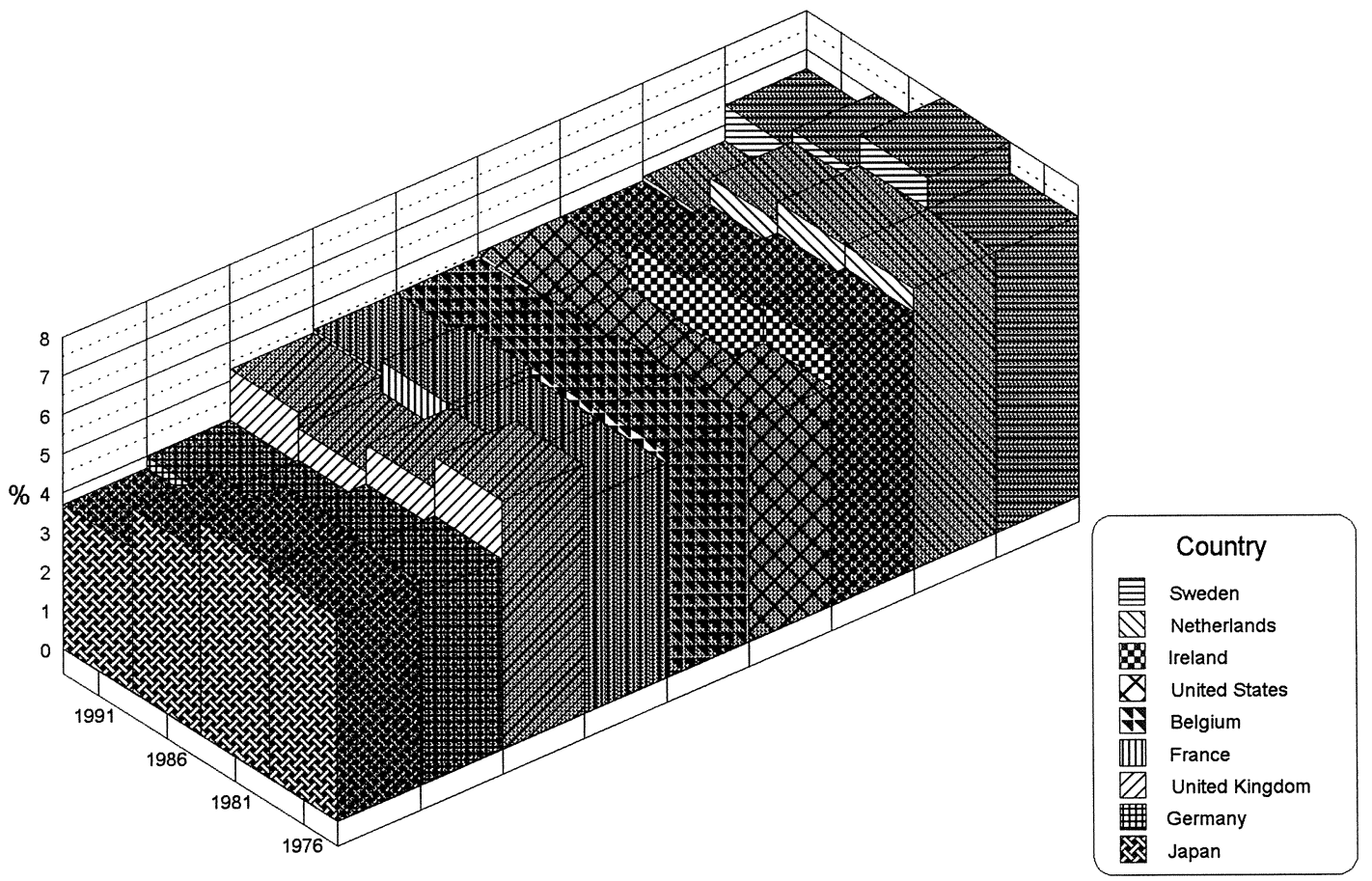

Source: OECD 
Graph 3.2

Convergence/divergence in real public expenditure on education as a percentage of real GDP, 1975 - 1991

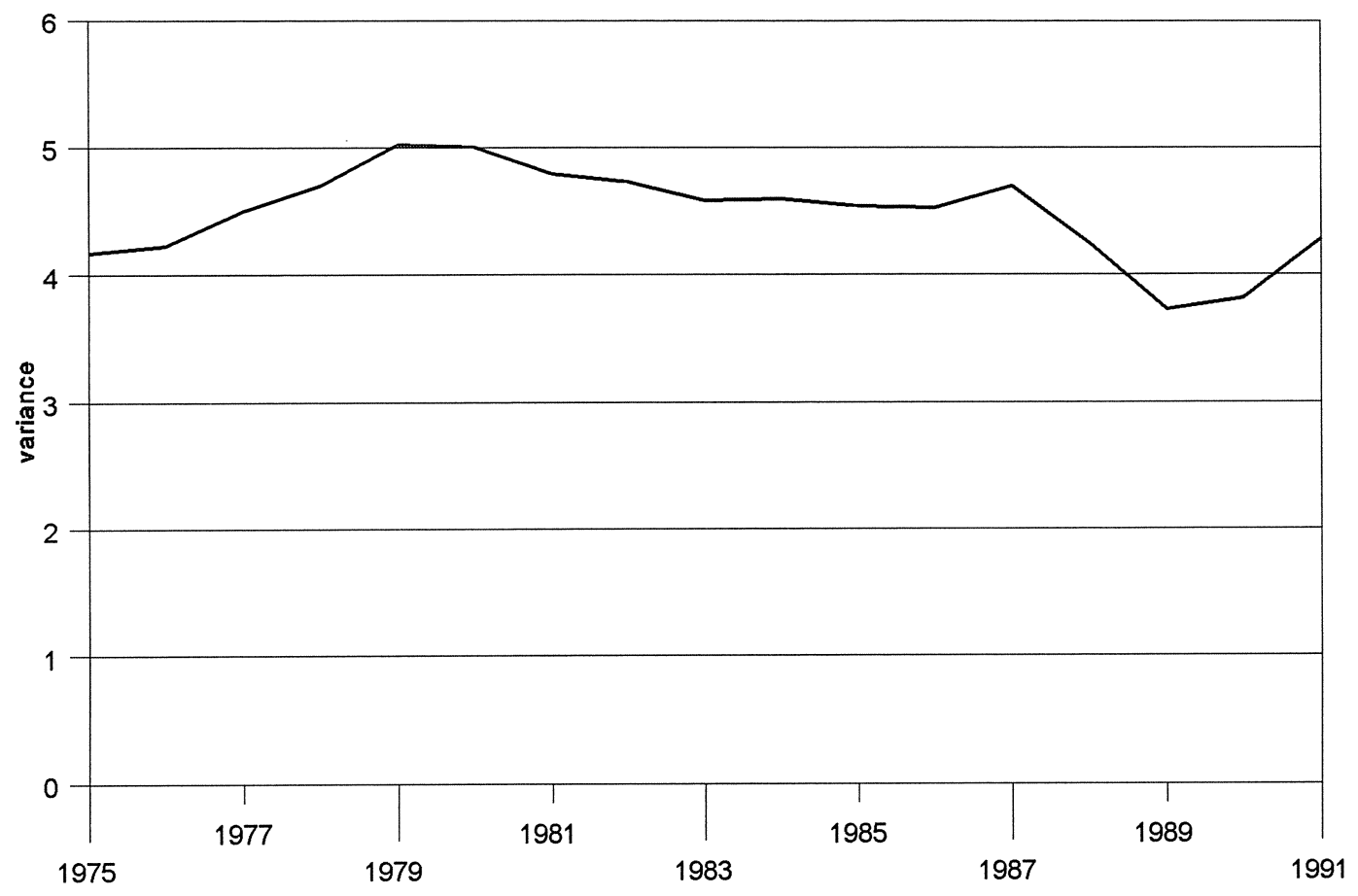

Source: ROA

Graph 3.3

Public expenditure per student in equivalent US dollars, converted using purchasing power parities, 1986 - 1991

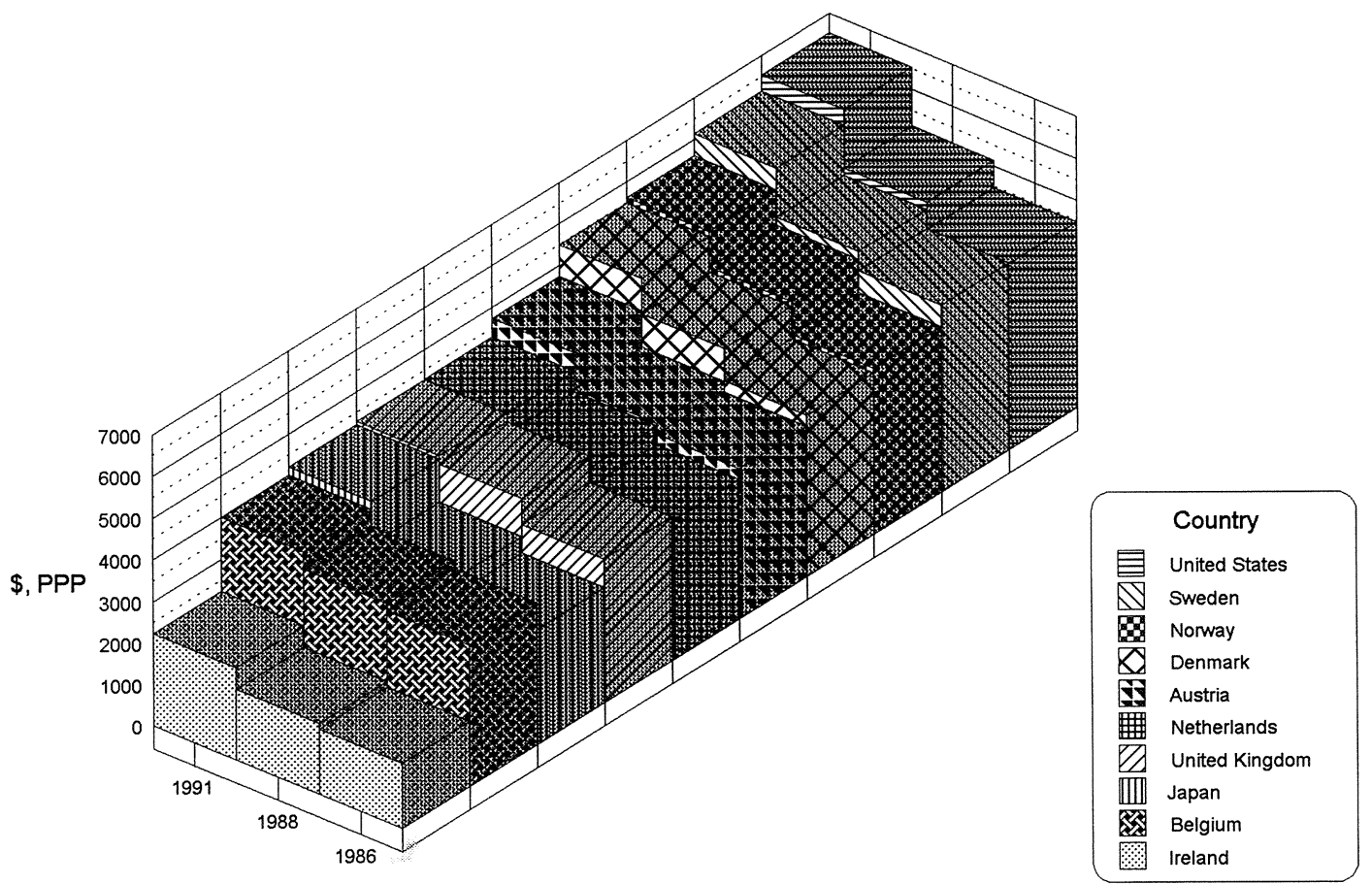

Source: OECD/ROA 
Graph 3.4

Convergence/divergence in public expenditure per student in equivalent US dollars converted using purchasing power parities, 1986 - 1991

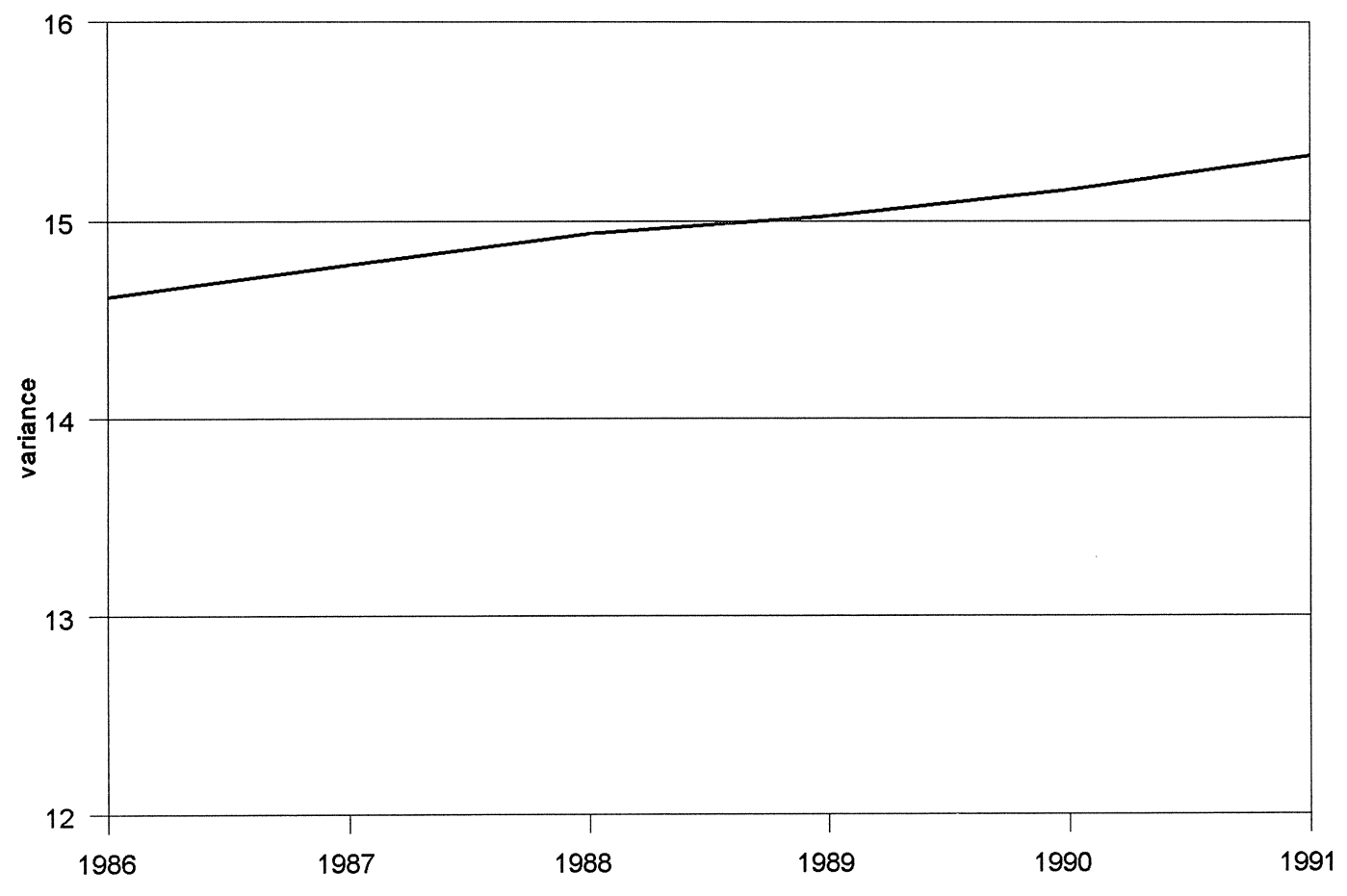

Source: ROA

\subsection{Higher education}

\section{Spending on higher education}

Higher education is an important feature of the innovative capacity of a nation. This holds for both the innovation itself and the diffusion of technological advances. Most people employed in R\&D have received higher education (CBS, Speur- en Ontwikkelingswerk in Nederland, 1994). As Bartel and Lichtenberg (1987) indicate, highly-skilled workers also play a major role in implementing new technology in the various sectors of the economy.

Graph 3.5 shows public expenditure per student in higher education. ${ }^{10}$ Here too, the United States spent most per student. Public expenditure per student in the United States lies far above that of the second highest spender, the Netherlands. However, of all these countries, only the Netherlands includes substantial subsidies for student living expenses in its costs per student. The actual expenditure in the Netherlands is thus lower than the graph suggests.

Public expenditure per student in higher education also shows a diverging trend (i.e., the differences between the countries have become larger), as can be seen from graph 3.6. Expenditure per student in higher education is only one way of looking at the relative importance placed on this kind of education by a nation. It is only an input measure, although it is probably also an indirect measure of a country's awareness of the relevance of a highly-educated labour force in keeping up with technological change.

10. Once again, for Japan and the Netherlands the results are for public and private expenditure. 
Graph 3.5

Public expenditure per student in higher education, in equivalent US dollars converted using purchasing power parities, $1986-1991$

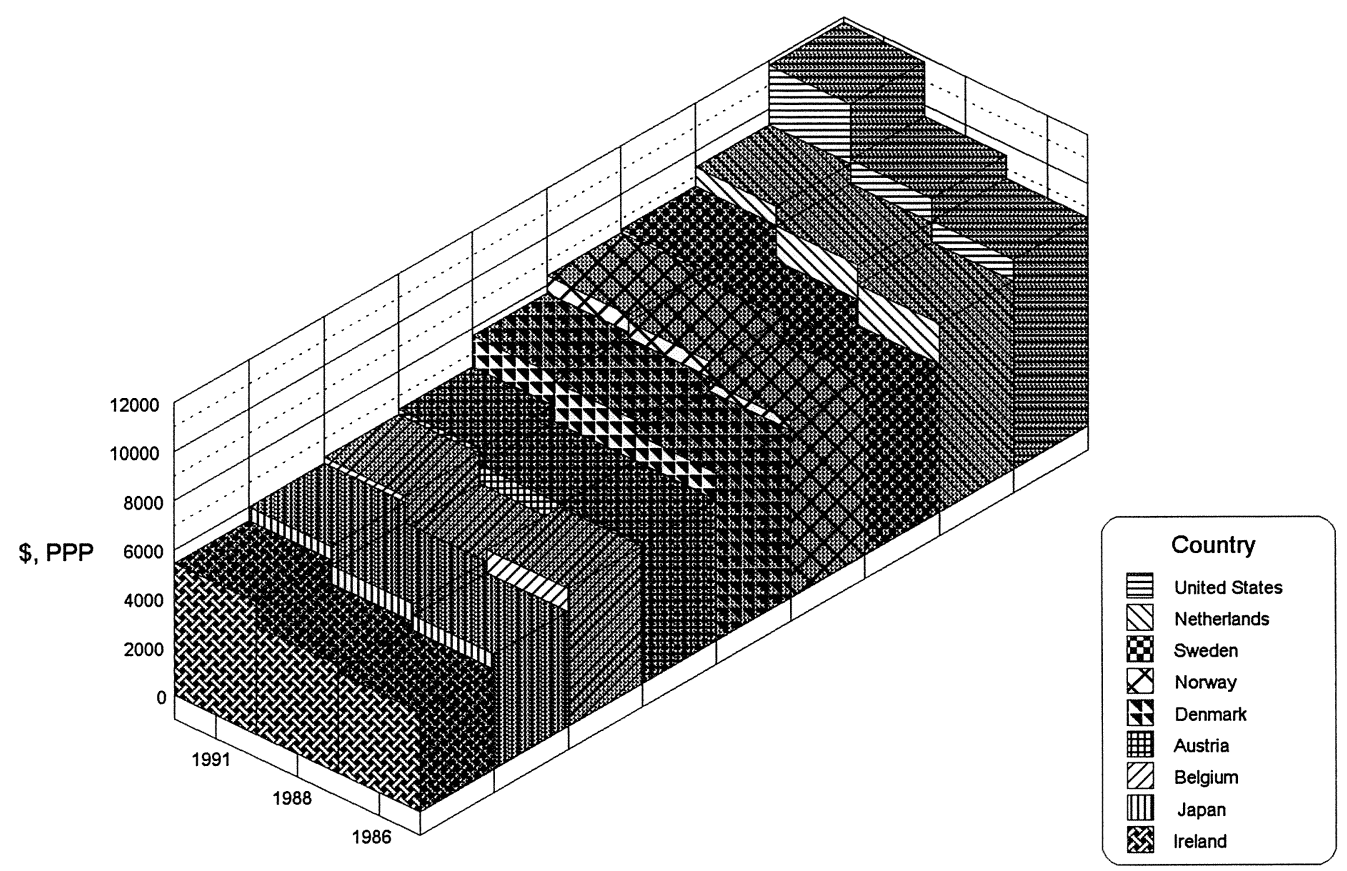

Source: OECD/ROA

Graph 3.6

Convergence/divergence in public expenditure in higher education in equivalent US dollars, converted using purchasing power parities, 1986 - 1991

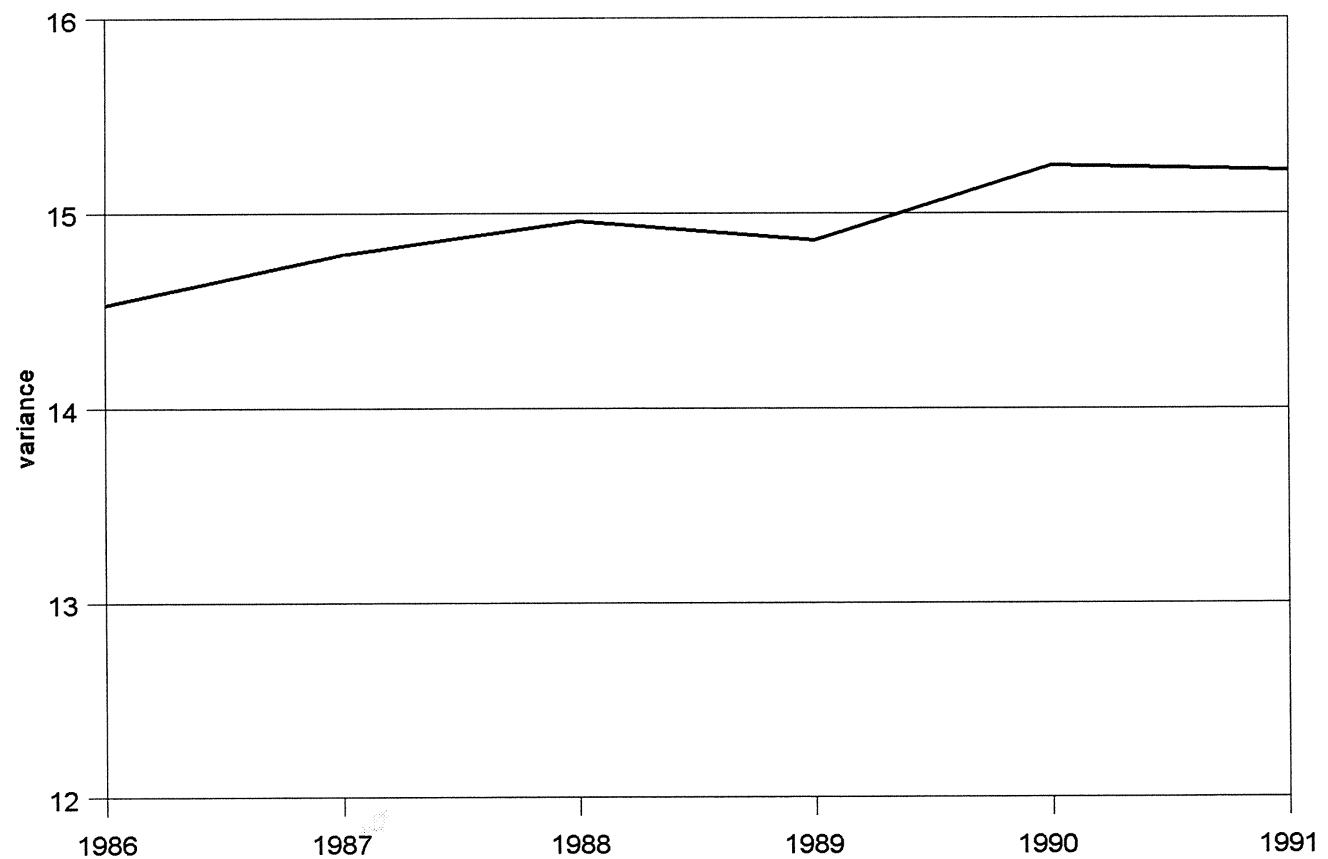

Source: ROA 
One important indicator of the innovative capacity of a country is the share of the technically educated in the total flows leaving higher education, as these are the people who often have to take the lead in the innovation process and in the management systems which make decisions about technological diffusion. As mentioned before, people with higher technical education have a leading role in R\&D.

The OECD report Education at a glance offers the possibility to highlight the share of technically educated graduates in university education. Graph 3.7 shows the number of degrees in sciences ${ }^{11}$ as a proportion of total university degrees. The proportion for 1991 ranges from almost $32 \%$ in Germany to slightly more than $15 \%$ in the United States. The differences between countries are thus very large. Looking at the developments over time, we can see that only in the United States and the Netherlands has the proportion of scientific degrees decreased, whereas these countries already had a very low proportion of university students graduating in science. All other countries show an increase in the proportion of scientific degrees, and Germany, Sweden and Denmark show very large increases. In general these developments seem to indicate that the Netherlands has begun to fall behind, and the United States even more so.

Graph 3.7

Degrees in sciences as a proportion of total university degrees, 1985 - 1991

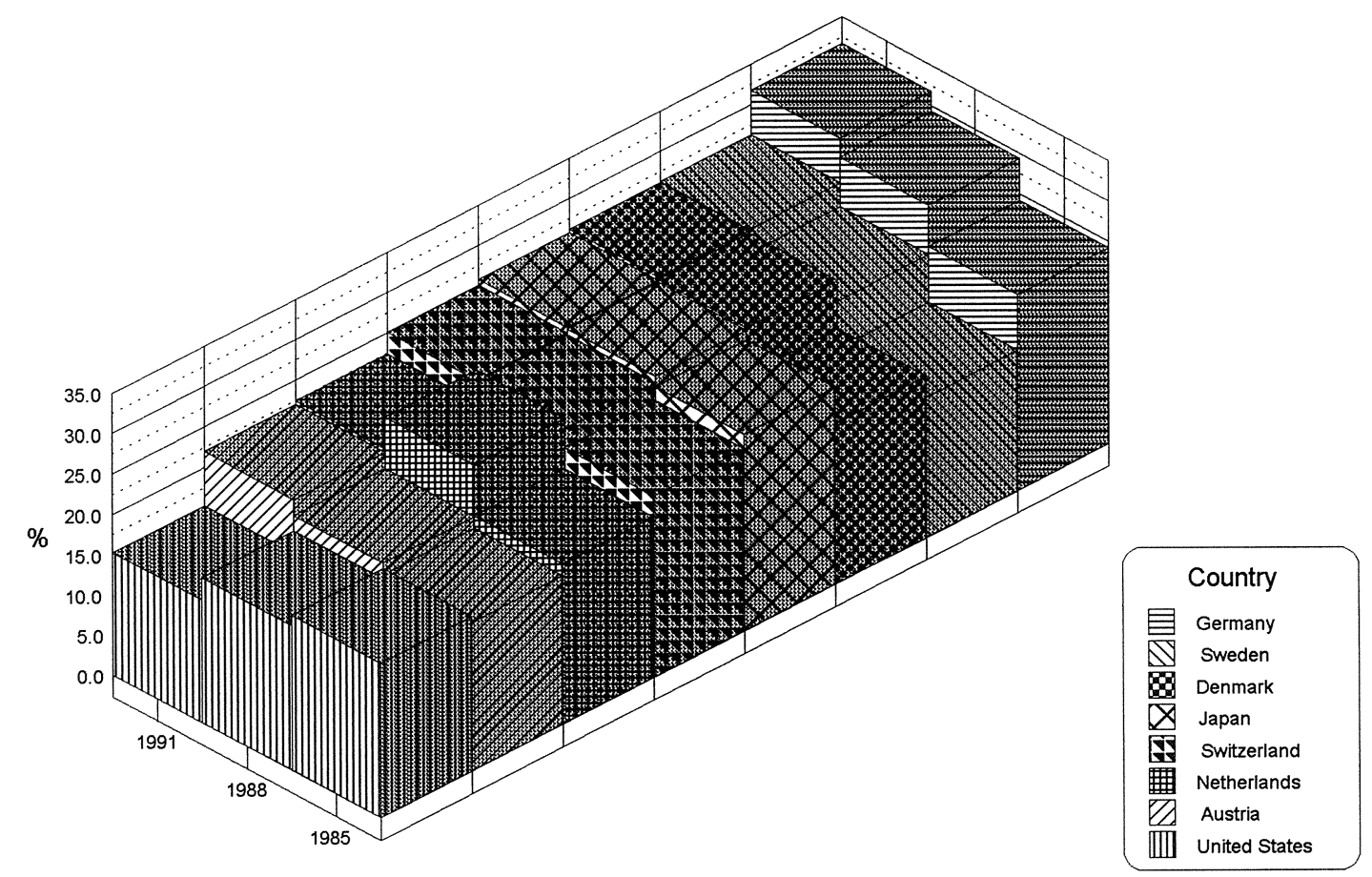

Source: OECDIROA

11. This indicator shows the number of university degrees awarded in each of three areas of science - the natural sciences, mathematics and computer science, and engineering - as a percentage of all university degrees awarded at ISCED levels 6 and 7 . The natural sciences include astronomy, biology, chemistry and physics (OECD, 1993). 
Graph 3.8

Degrees awarded in natural science as a percentage of total university degrees, $1985-1991$

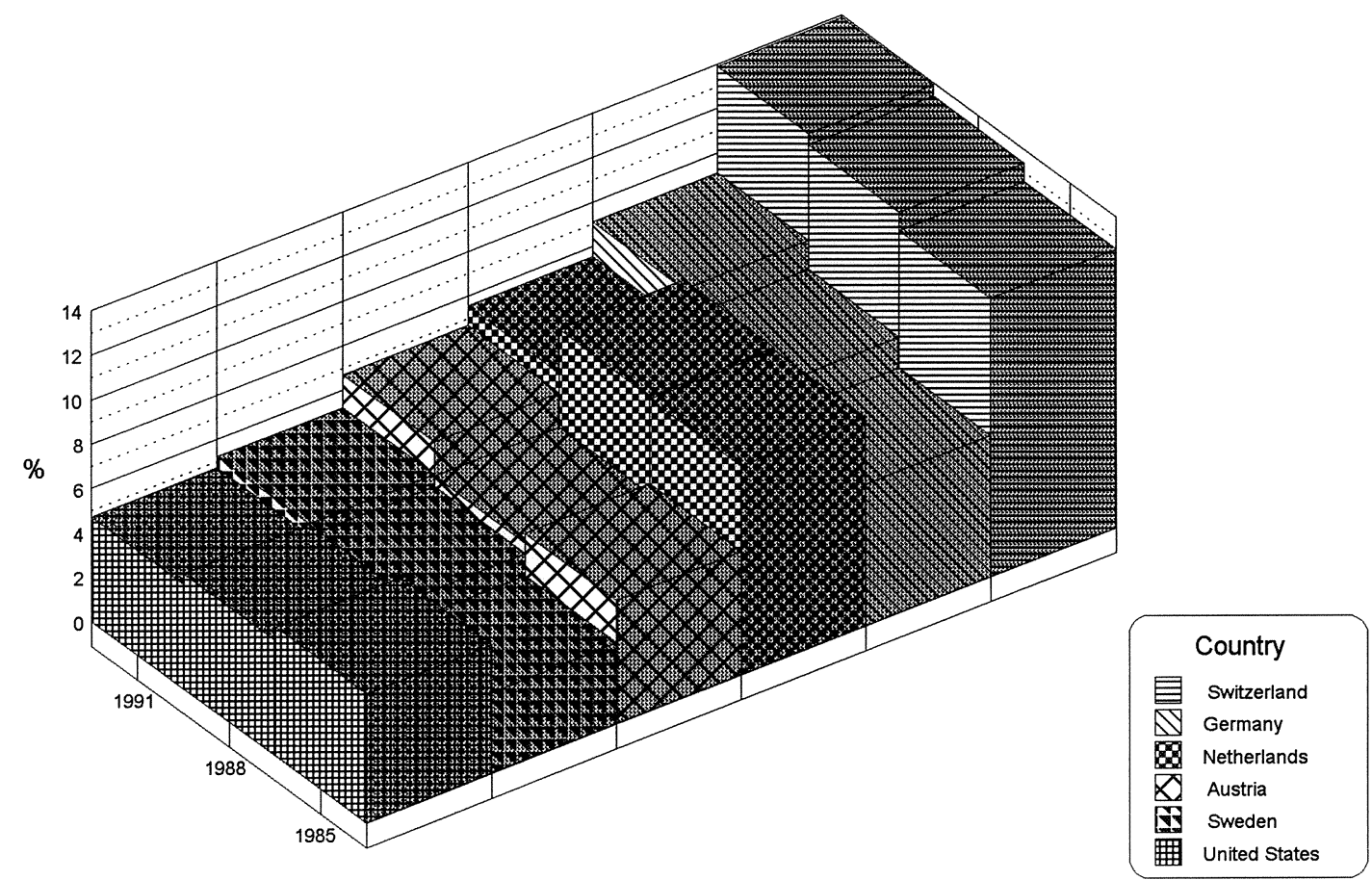

Source: OECD/ROA

Graph 3.9

Degrees awarded in mathematics and computer science as a percentage of total university degrees, $1985-1991$

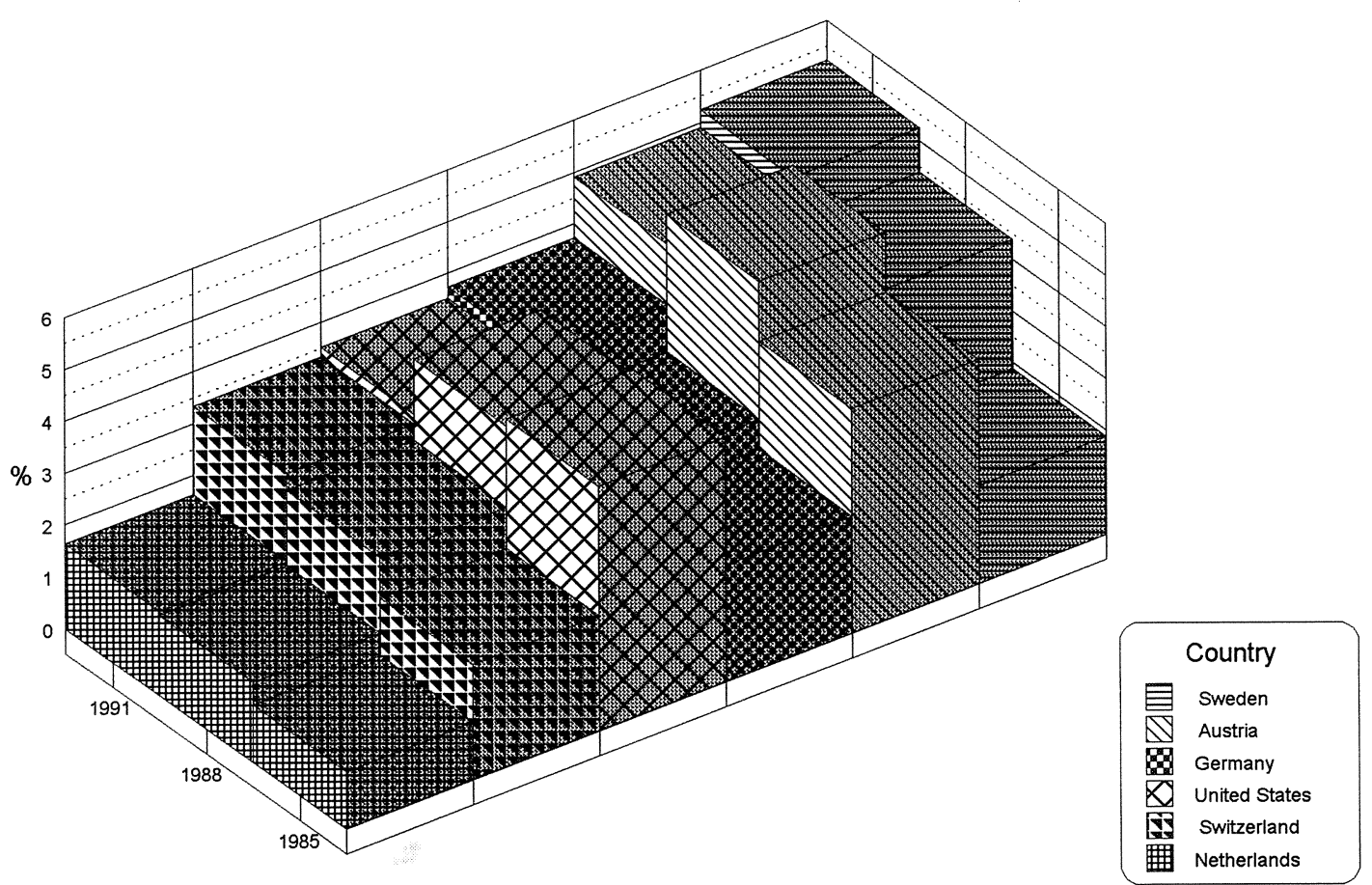

Source: OECD/ROA 
For some countries, the overall science figures can be broken down further, to distinguish between degrees in natural science, mathematics and computer science, and engineering (graphs 3.8 to 3.10). The graphs indicate that the countries emphasize different aspects of scientific studies. Germany, Sweden and the Netherlands, have a strong emphasis on engineering, in Sweden and Austria are strong in mathematics and computer science, and Switzerland is far ahead of other countries in the number of natural science degrees awarded. The graphs also show the extremely weak position of the Netherlands in mathematics and computer science. The proportion of all degrees which are awarded in this field is less than half that in Switzerland, the country with the second lowest proportion of degrees in this field. In Germany and Sweden, the increase in the proportion of degrees in the sciences is spread over all scientific disciplines. Especially in comparison with these two countries, the Netherlands is falling behind quickly.

\section{Graph 3.10}

Degrees awarded in engineering as a percentage of total university degrees, $1985-1991$

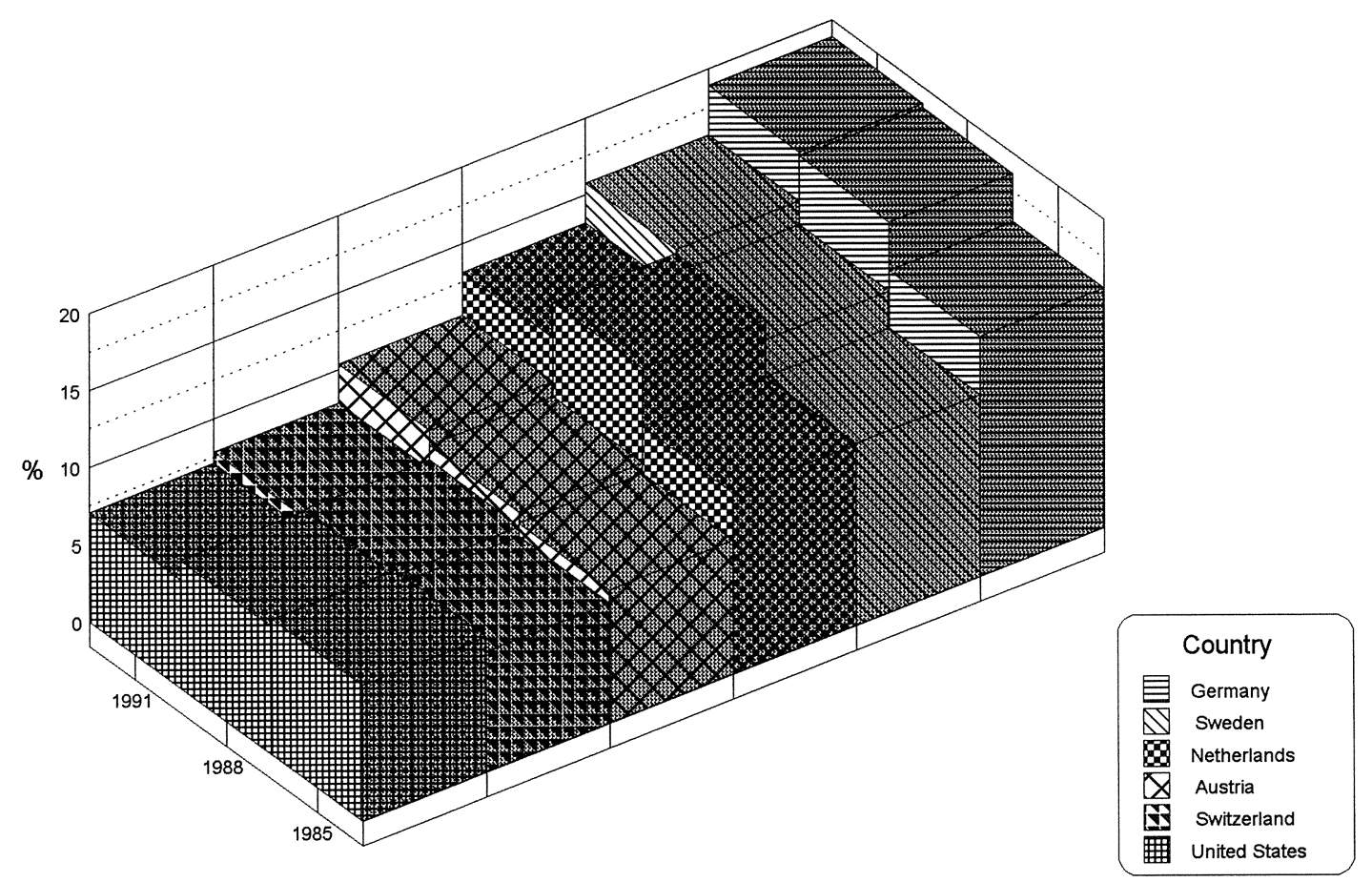

Source: OECD/ROA

\section{Conclusion}

The first part of this section showed that the Netherlands spends a relatively large percentage of its gross domestic product on education. However, the expenditures for the Netherlands include substantial public subsidies for student living expenses. Moreover, graph 3.1 also showed that this percentage was strongly decreasing to the average level. When looking at the expenditure per student, it can also be observed that the Netherlands holds a position in the middle of the spectrum.

The second part of the section showed the number of degrees in science as a percentage of all university degrees. Overall the proportion of students with a science degree in the Netherlands is decreasing, although this proportion was already low. The only science field showing increasing shares 
of overall degrees is mathematics and computer science. However, this still indicates that the Netherlands is starting to fall behind other highly-developed countries on this point.

\subsection{Vocational education}

Vocational education in the broad sense

Workers with a broad initial vocational education tend to be better able to adapt their skills to the requirements due to technological innovations than workers who have gained their skills in practice, by on-the-job training, as the latter often do not have enough of the theoretical knowledge required for additional training. The share of vocational education students (second and third levels) ${ }^{12}$ in the total number of second and third level students can be interpreted as an indicator of the degree to which a country's future workforce will be open to technological advance in their later careers, and so is an indicator of the fertility of the breeding grounds for technology diffusion processes.

Graph 3.11

Indicator of the share of vocational education in all education, 1975 - 1991

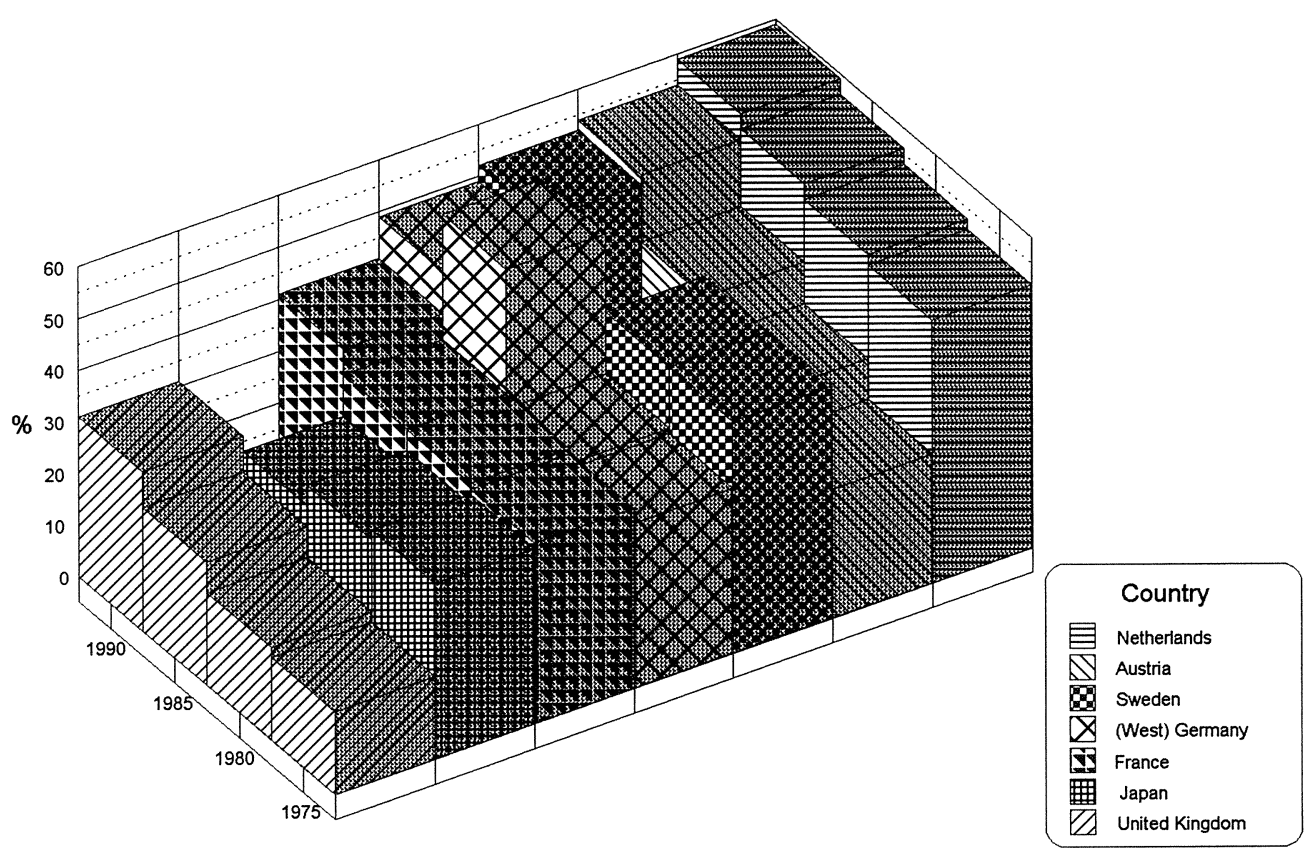

Source: UNESCO/ROA

Graph 3.11 presents the share of 'vocational education' in total education. Because of the nature of the available data, we have had to use a very broad definition of vocational education. This means that only primary and general secondary education are excluded. Vocational education in this case can be considered to indicate the openness of a society to the diffusion of technological change. A higher share of vocational education may also be considered to add to the society's innovative potential. The graph shows that, using this broad definition of vocational education, the Netherlands has the highest proportion of vocational students, followed by Austria and Sweden. In the eighties, the share of

12. The second and third levels comprise all education beyond the elementary stage. 
vocational education has tended to rise in most countries, and has declined only in Japan. The sharp rise for Germany in 1985 is due to a change in the definition of vocational education in this country. For the Netherlands, the share of vocational education is expected to increase further in coming years, although the share of intermediate vocational education in the Netherlands is decreasing, due to increasing participation in higher education, as could be seen in graph 2.24. From graph 3.12 it can be seen that the differences between countries have remained stable over time.

Graph 3.12

Convergence/divergence, between countries, in the share of vocational education, $1980-1990$

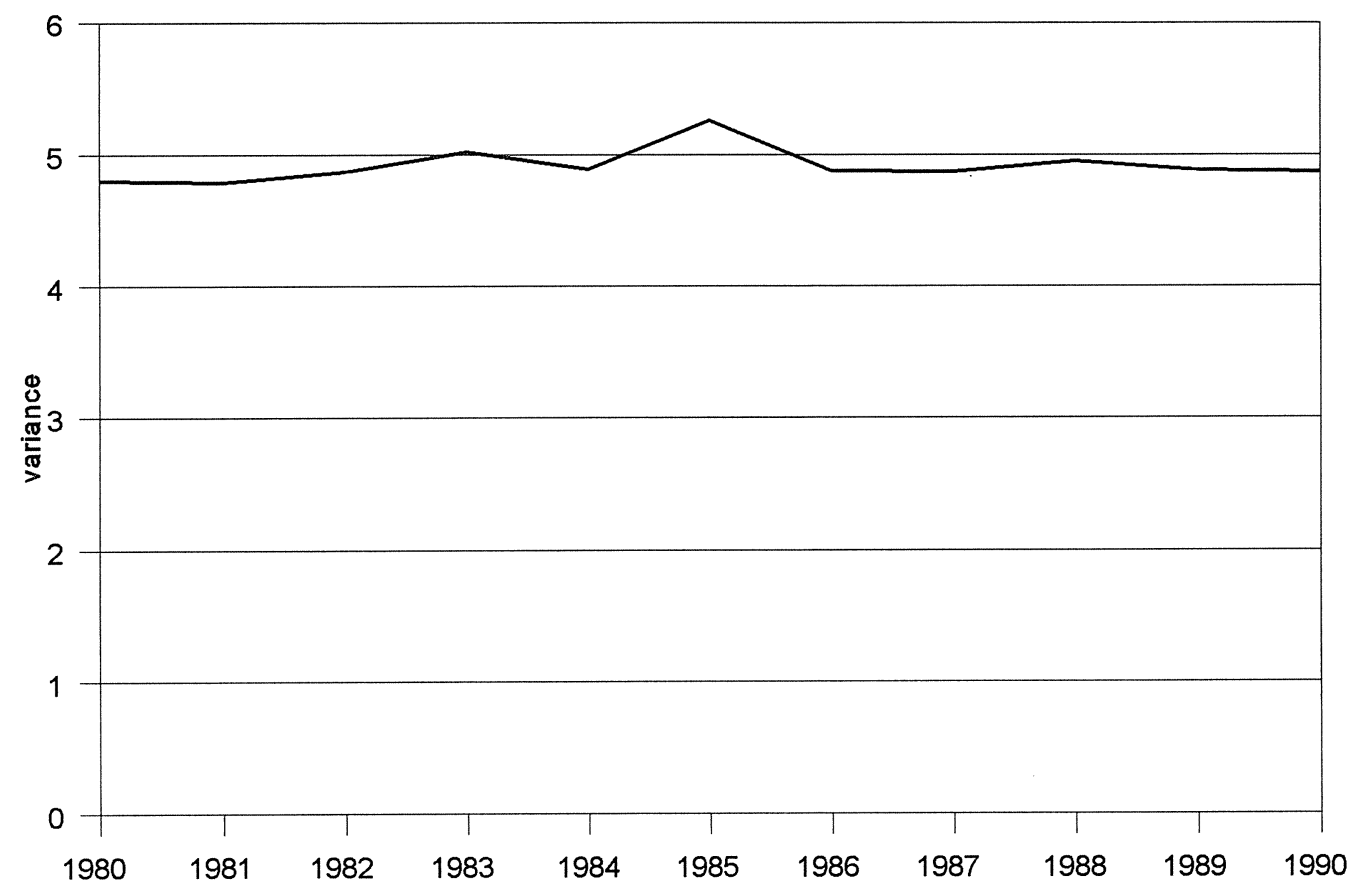

Source: ROA

\section{Participation in dual education}

Dual education is the collective name for types of education that combine learning and working to provide students with basic skills for their future careers. In the Netherlands, most dual education takes the form of apprenticeships. The dual system is an important 'linking pin' between education and the labour market at the intermediate level (see e.g. Ryan, 1991). In fact, dual education seems to be an optimal way to combine theoretical knowledge and practical application, and thus can be seen as an ideal way to acquire the skills required for new technologies.

Graph 3.13 shows that dual education is very important in Denmark and Germany. The marked decrease in the share of dual education in Denmark is due to a change in the definition of dual education in the Labour Force Surveys in 1992. On this measure, these two countries would be expected to be more flexible and better able to adapt to technological change.

Graph 3.14 shows that there is a slight converging trend in the shares of dual system students in the younger age-groups of the populations of the various EU countries. 
Graph 3.13

Share of dual system students in the population aged 15-24, $1984-1992$

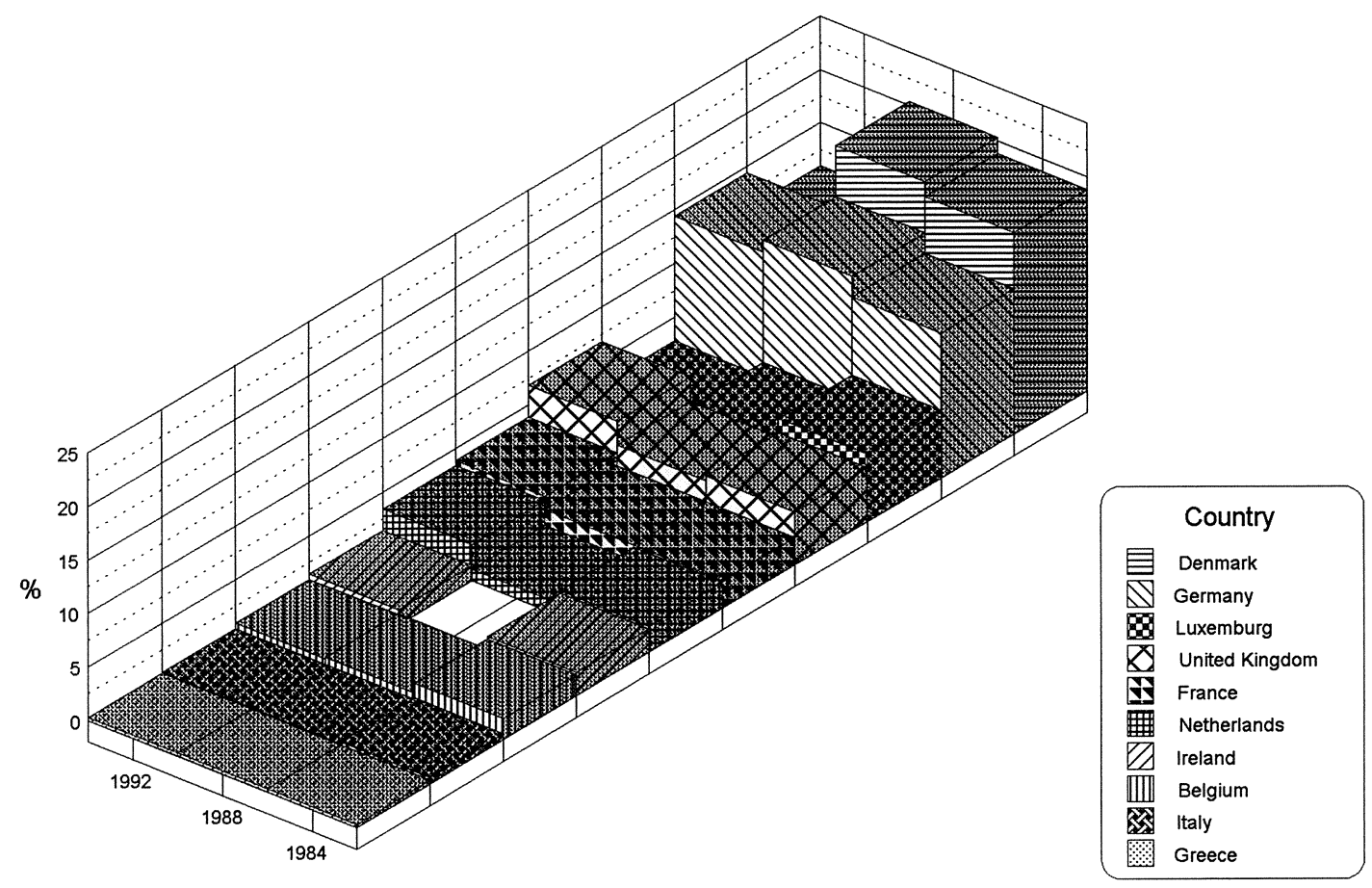

Source: EUROSTAT/ROA

Graph 3.14

Convergence in the share of dual system students in the population aged 15-24, $1984-1992$

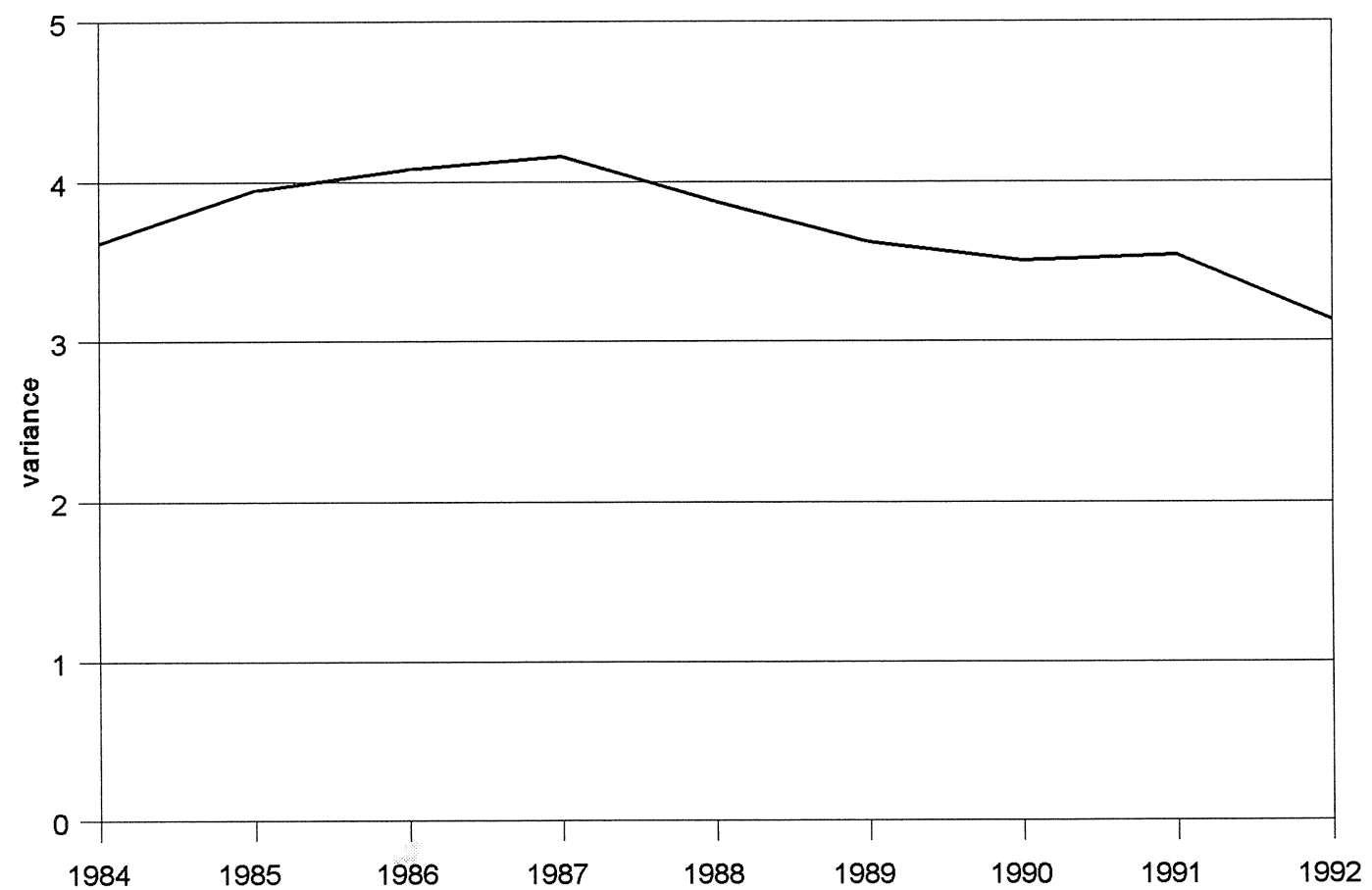

Source: ROA 
As already mentioned, in the Netherlands, and probably in all other countries, most dual education takes the form of apprenticeships. In the Netherlands there are two level of apprenticeships: primary apprenticeships (basic courses, leading to the 'starting qualification' to work in a profession) and secondary apprenticeships (advanced courses, leading to the status of tradesman). Most apprenticeship courses fall within the definition of intermediate level education, but some primary apprenticeships are on the low educational level.

\section{Apprenticeships in the Netherlands}

Graphs 3.15 and 3.17 present an indicator which relates the labour volume of apprentices undergoing primary or secondary apprenticeship training, respectively, to the labour volume of seven Dutch industrial sectors.

Graph 3.15

Share of primary apprentices' labour in the labour volume of Dutch industrial sectors, 1975 - 1992

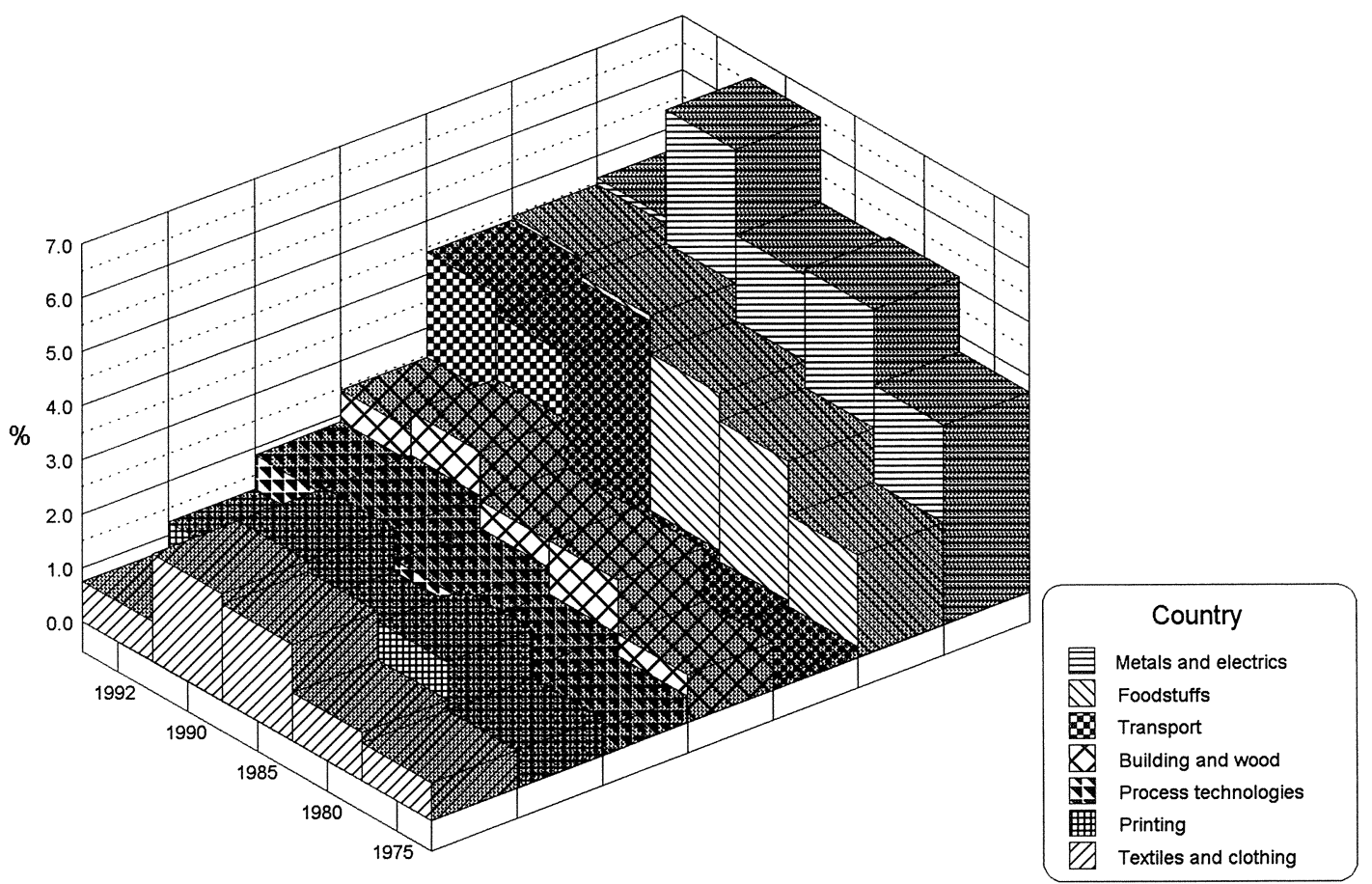

Source: $\mathrm{CBS} / \mathrm{CPB} / \mathrm{ROA}$

Graph 3.15 shows that during the eighties all sectors experienced an increase in the proportion of labour contributed by primary level apprentices. ${ }^{13}$ This increase was smallest in the printing sector and largest in the foodstuffs sector, the transport sector and the metals and electrical sector. The latter three sectors now have the highest proportions of labour contributed by primary level apprenticeships. This

13. The labour volume for each employment sector is determined here by adding the labour volumes of the corresponding industrial sectors. The number of primary and secondary level apprenticeships for each sector is determined by aggregating the primary and secondary apprenticeships, respectively, which were being supervised by the various training institutions in a particular year. In calculating the apprentices' share in the labour volume, an apprenticeship is considered as $80 \%$ of a five-day working week (since apprentices in general spend one day per week in school). Therefore the number of apprenticeships has been multiplied by the labour hour factor of 0.8 . The numbers in the graphs represent the percentages of primary apprentices' labour or secondary apprentices' labour in the labour volume of industrial sectors. 
large increase was probably due to the 'doubling operation'. In the early 1980 s the demand in the Netherlands for apprentices was much less than the number of young people wanting to begin apprenticeships. The short supply of apprenticeship places, combined with the threat of future shortages of trained workers, led employers' and employees' organisations, educational authorities and the government to make joint agreements to strengthen the apprenticeship system (see Adviescommissie inzake de Voortgang van het Industriebeleid, 1983). The goal was to double the number of apprenticeships, as compared to the index year of 1982. Since 1990, however, the share of industrial labour contributed by primary level apprentices has been decreasing in a number of sectors, especially in the metals and electrics sector and the textiles and clothing sector.

A divergence/convergence analysis has also been performed for this measure, based not on differences between countries but rather on differences between sectors. Graph 3.16 shows that the 'doubling operation' of the 1980s led to a large divergence between the various industrial sectors, since primary apprenticeships increased most in the 1980s in the metals and electronics sector and the foodstuffs sector. The converging trend at the end of the $1980 \mathrm{~s}$ is probably related to a kind of catching-up process, especially in the transport sector, since 1990.

\section{Graph 3.16}

Convergence in the proportion of labour volume in seven Dutch industrial sectors contributed by primary apprentices, 1975 1992

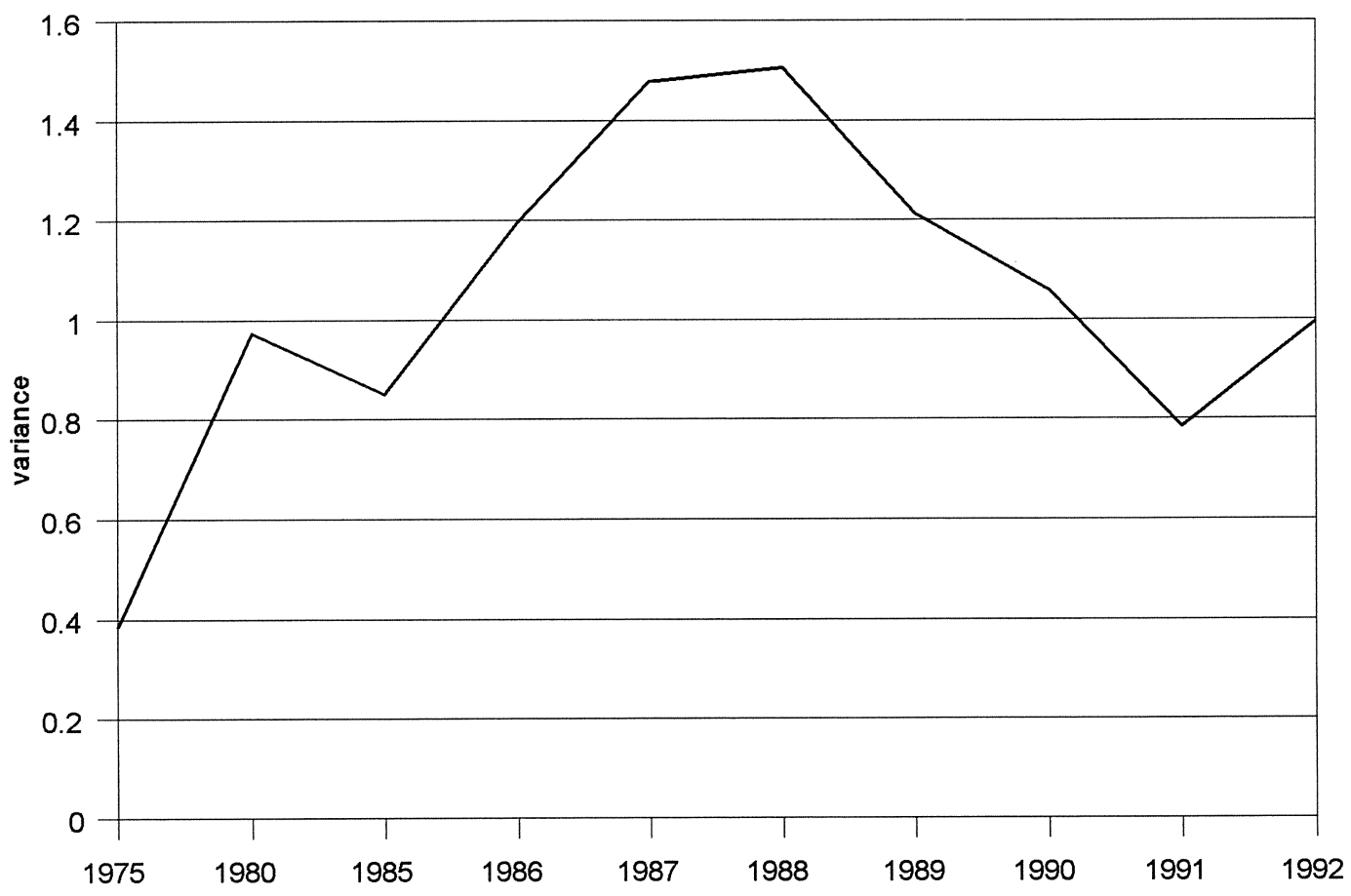

Source: ROA

Graph 3.17 shows the shares of labour volume in the same industrial sectors which are contributed by secondary apprentices. As can be seen, the labour volume shares of secondary level apprenticeships are lower than the shares contributed by primary level apprentices. This indicates that only some of the primary level apprentices continue their training in secondary level apprenticeships. Participation in secondary level apprenticeships also increased during the eighties, and is now highest in the metals 
and electrics sector, the foodstuffs sector and the process technologies sector. Since 1990, participation in secondary level apprenticeships seems to have stabilized in most sectors. The graph also shows the results of the 'doubling operation' very clearly. The proportion of labour volume contributed by secondary apprentices doubled in almost all sectors.

The convergence/divergence analysis in graph 3.18 shows that the doubling operation also increased the differences between the sectors as regards secondary apprenticeships.

Graph 3.17

Share of secondary apprentices' labour in the labour volume of Dutch industrial sectors, 1975 - 1992

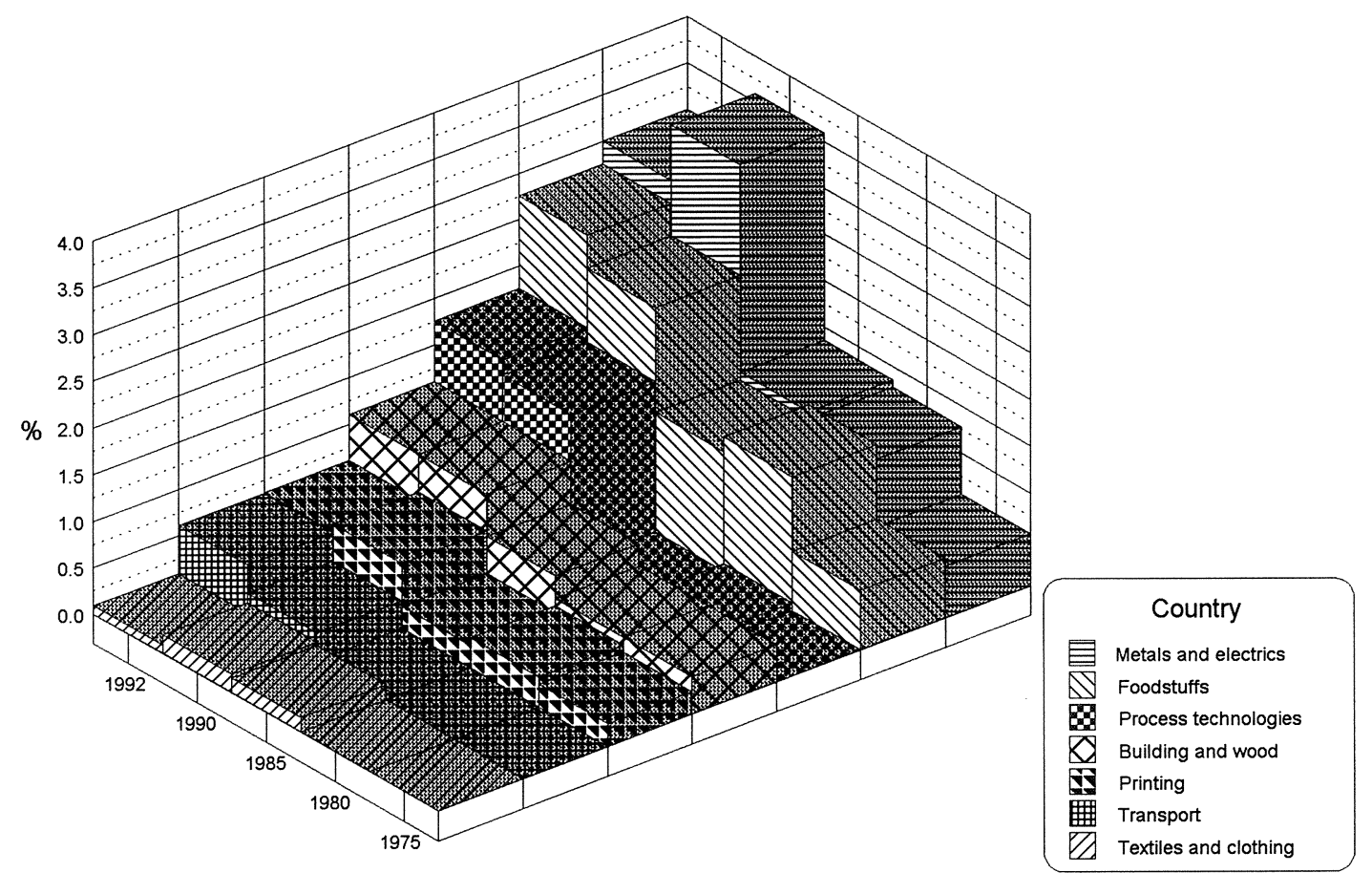

Source: CBS/CPB/ROA

Projections to the year 2001 for primary apprenticeships in the Netherlands show decreasing numbers of apprentices (De Grip, Berendsen, Borghans \& Dekker, 1994). In a base-line scenario, the expected annual qualified outflow in absolute numbers is expected to decrease from 22,260 in 1991 to 16,027 in 1997, recovering to 19,643 in 2001 . Overall this would lead to an total shortage of 12,411 primary apprentices in 1997 and of 15,833 primary apprentices in 2001, as table 3.1 shows.

The greatest shortages are expected in the sectors with the highest planned increases in their intakes: road transport ( $74 \%$ shortfall) and the textile industry ( $61 \%$ shortfall). Other sectors which are expected to face large relative apprentice shortages are the baking industry ( $40 \%$ shortfall), the building trades ( $35 \%$ shortfall), the administrative occupations ( $34 \%$ shortfall) and construction workers for civil engineering (34\% shortfall).

According to expectations, by 1997 only a few sectors within the apprenticeship system will not (yet) be facing shortages in their apprentice intakes: hairdressing, technical trades in health care and the vehicle and bicycle trade. The ready-made clothing industry and the nursing and care-giving occupations will 
also suffer little or no shortage of apprentices. For hairdressing, in fact, a relatively large excess in supply is expected.

Table 3.1

Expected over-supplies and shortages of new apprentices under the base-line scenario, 1997 and 2001, (in absolute figures and as percentages of the planned intake)

\begin{tabular}{lrrrr}
\hline Supervisory & \multicolumn{2}{c}{1997} & & 2001 \\
Board & number & $\%$ & number & $\%$ \\
\hline Wholesale and retail & & & $-1,149$ & -21 \\
Administration & $-1,608$ & -29 & -948 & -43 \\
Road Transport & -746 & -34 & $-2,738$ & -79 \\
Metals Industries & $-2,589$ & -74 & $-1,787$ & -39 \\
Building & $-1,141$ & -25 & $-1,833$ & -46 \\
Painters & $-1,389$ & -35 & -587 & -40 \\
Vehicle and Bicycle trade & -402 & -27 & -293 & -10 \\
Confectionary & 92 & 3 & -85 & -20 \\
Electricians & -78 & -18 & $-2,269$ & -45 \\
Health Care, technical trades & $-1,386$ & -28 & 132 & 29 \\
Printing sector & 46 & 10 & -583 & -39 \\
Ready-made clothing & -439 & -29 & 21 & 5 \\
Hotel and catering & -2 & -1 & -881 & -30 \\
Processing industry & -675 & -23 & -298 & -21 \\
Nursing and care-giving & -146 & -10 & 23 & 1 \\
Civil engineering construction & -38 & -2 & -553 & -50 \\
Coach builders and panel-beaters & -371 & -34 & -200 & -20 \\
Textile industry & -163 & -16 & -295 & -60 \\
Carpenters and cabinet-makers & -300 & -61 & -529 & -44 \\
Bakery workers & -365 & -30 & -417 & -55 \\
Hairdressing & -303 & -40 & 827 & 36 \\
Butchers & 701 & 30 & -363 & -25 \\
Installation engineers & -337 & -23 & -958 & -40 \\
Total & -705 & -29 & $-15,833$ & -32 \\
& & & & \\
& $-12,411$ & -25 & & \\
\end{tabular}

In 2001 the same apprenticeship boards, in general, will face relatively large shortfalls as in 1997, but with marked increases in the shortfall expected for electricians (from $28 \%$ to $45 \%$ ), construction workers for civil engineering (from $34 \%$ to $50 \%$ ) and bakery workers (from $40 \%$ to $55 \%$ ). The over-supply in the vehicle and bicycle trade in 1997 will turn into a shortfall in 2001.

One of the biggest problems of the apprenticeship system is the very high drop-out rate. Drop-out rates vary from $32 \%$ in the printing sector to $62 \%$ for electricians. Meijer (1994) shows that there are various reasons for the high drop-out rates of the primary apprenticeships in the Netherlands. The most common problem is that, in the Netherlands, apprentices are often drop-outs from earlier education, and thus have a relatively low motivation and educational background. Combined with the problem that apprenticeships often include relatively difficult theoretical components, this makes for high drop-out rates. 
Convergence in the proportion of labour volume in seven Dutch industrial sectors contributed by secondary apprentices, $1975-1992$

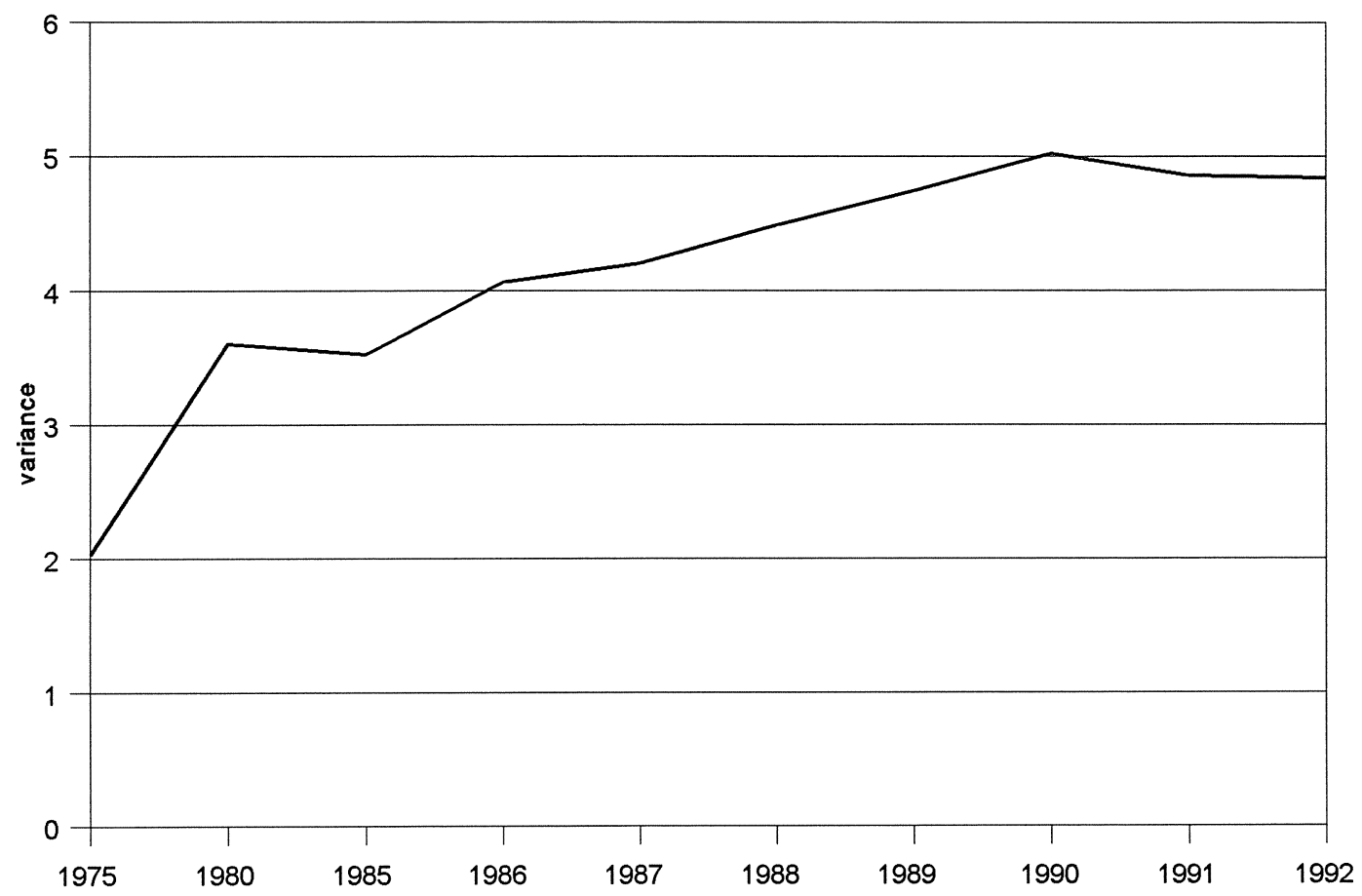

Source: ROA

The image of technology among young people

As already mentioned, the 'doubling operation' achieved its goal at the end of the 1980s. The graphs above also show that, in the early 1990s, the numbers of apprentices started to decline again, as there was not enough interest among young people. What has particularly caused anxiety in this connection is the decrease in the flow of pupils coming from Lower Vocational Education and Junior General Secondary Education. The decrease in the flows from these educational categories is partly demographically determined. However, there is also a strong tendency in the Netherlands for students to stay longer in full-time education. A third explanation may be found in the relatively bad image which technology has among young people. Many apprenticeships are related to technology and thus suffer, along with all other forms of technical education, from this image problem.

A study by Willems and De Grip (1993) among 2,000 young people showed that only $24 \%$ of all young people would eventually choose a technological education or occupation. Figure 3.1 shows how this comes about. At the end of their primary education, $9 \%$ of all boys and $24 \%$ of all girls choose a form of education which prevents them from later choosing a technological path. After secondary education, only $51 \%$ of the boys and $16 \%$ of the girls remain able to choose a technological path. Finally, $44 \%$ of the boys and $6 \%$ of all girls actually choose a technical study or occupation. Altogether this means that $24 \%$ of all young people choose a technical study or profession. In the end, the percentage will be lower, as not all young people who choose a technical course of study will find employment in a technical job. 
This study also examined the image of technology and students' attitudes to technology. Three dimensions of students' attitude to technology were distinguished: interest in technology, technology assessment and the role of women in technology. It was found that in general boys are highly interested, and girls are hardly interested, in technology. In general, young people have a positive opinion of the consequences for society of technological progress, with girls being somewhat more critical than boys in this respect. In particular, their assessment of the social consequences is more negative. Both boys and girls have a predominantly positive attitude to women's role in technology. The attitude of young people belonging to ethnic minority groups is much more negative in this respect.

Figure 3.1

The technology funnel: boys and girls in the Netherlands

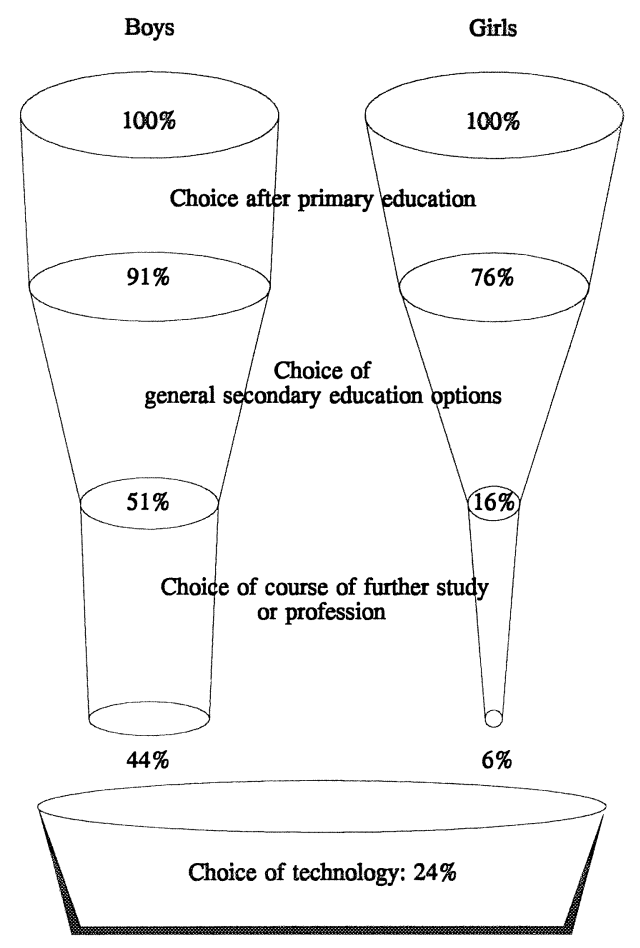

Source: ROA

It was found that technical studies have the image of being difficult. Girls and ethnic minority groups, in particular, think that technical studies are difficult compared to other types of education. By contrast, the pupils' image of the labour market position of technically trained people was predominantly positive. Their chance of getting a job and their incomes were thought to be relatively high. Girls think somewhat less positively about the labour market position of technically trained people than boys. Most pupils have a rather 'traditional' opinion of technicians' working conditions. The work is thought to be heavy and occasionally dirty. However the pupils thought that the psychological strain of such work is rather low, as is the chance of the work being dull. In addition, technicians are thought to be rather independent in executing their tasks. In general, the pupils were rather well-informed about the actual labour market situation of technically trained people. However, their image of the working conditions was on the whole too negative compared to reality. Especially the image of technical work as being heavy and dirty does not fully correspond with reality. 


\section{Conclusion}

Approximately $60 \%$ of students in the Netherlands are following 'vocational education', broadly defined. This was by far the highest percentage of the countries mentioned. However, as mentioned earlier, relatively few students are in technical vocational education. The previous section showed that the percentage of students graduating in science at the university level is even decreasing.

Dual education is very important in Denmark and Germany, as a 'linking pin' between education and the labour market at the intermediate level. The divergence/convergence analysis showed convergence on this point between the various countries. However, this convergence has been caused by decreases in the participation in dual education in most countries, which cannot be seen as a positive development.

After a strong decrease in the number of apprenticeships in the Netherlands during the mid 1980s, there has been a decrease in most sectors in the early 1990s. Projections until the year 2001 show that most fields will suffer shortages. The conclusion to be drawn from the alternative scenarios is that part of the problem of apprenticeships can be solved by decreasing the drop-out rate, but that other policy measures have also to be taken. One possibility is attracting more women to take up apprenticeships. However, apprenticeships are largely related to technical occupations, and given the image which technology has and the attitude of women to technology, it will probably be very difficult to achieve this goal.

Finally, with regard to the image of technology, it can be seen that few students choose further technical studies or an occupation in technology. The main reasons can be found in a rather low level of interest in technology, especially on the part of women, and in the bad image of technical work and studies. Technical studies are considered to be difficult and technical jobs are often considered as dull, heavy and dirty. This indicates that the image of the working conditions on the whole is too negative compared to reality. The image of technical studies and technical jobs will have to be polished up if more students are to be attracted to technical fields.

\subsection{Unemployment and labour market prospects for Dutch school-leavers}

Since 1991, ROA has carried out two national research projects every year, among school-leavers in the Netherlands. The first project, called RUBS (Registration of the Outflow and Destination of Schoolleavers), is a nation-wide postal survey of school-leavers (whether as drop-outs or with qualifications) from general secondary education, and lower and intermediate vocational education in the Netherlands. The second research project, called the HBO Monitor, is a nation-wide postal survey of graduates from all sectors of higher vocational education (excluding higher agricultural education) in the Netherlands. Both RUBS and the HBO Monitor generate an up-to-date picture of the destination of last year's schoolleavers and graduates, their labour market position, and the match between education and the labour market, differentiated by type of education and vocational specialisation.

The proportion of school-leavers who are still unemployed one year after leaving school is a first indicator of the labour market position of school-leavers. This gives an indication of quantitative bottlenecks (absorption problems) on the labour market for school-leavers. Graph 3.20 shows unemployment levels one year after leaving school, for students who left school in 1991 and 1992. As well as reflecting the increasing unemployment levels among school-leavers at that time, the graph indicates that school-leavers with higher technical education have the greatest problems in finding a suitable job. However, we have to bear in mind that the highest level included here is the Dutch HBO 
schools, at a level roughly comparable with a bachelor's degree (ISCED 6). University students, all of whom do masters' courses, are not included in the sample, so no conclusions can be drawn about them. The graph also shows that unemployment among recent school-leavers with lower and intermediate vocational education is relatively low. The levels are not far from what is generally seen as the natural rate of unemployment of $2.5 \%$ (see e.g. CPB, 1992). However, for the 1992 school-leavers (i.e., their labour market position in 1993) it can be seen that unemployment for those with intermediate technical education rose above the level for all kinds of intermediate vocational education. This might indicate that an over-supply of people with intermediate technical education may arise in the near future. However, we have to keep in mind that data is available only for two years. Since unemployment is cyclically related, these results may be caused by a general downward shift in the economy, and coming years may see decreasing unemployment levels and perhaps even shortages of workers with a technical education.

Graph 3.20

Unemployment among Dutch vocational (lower, intermediate and higher ${ }^{\star}$ ) school-leavers ${ }^{\star \star}$ about one year after leaving school, 1991 and 1992

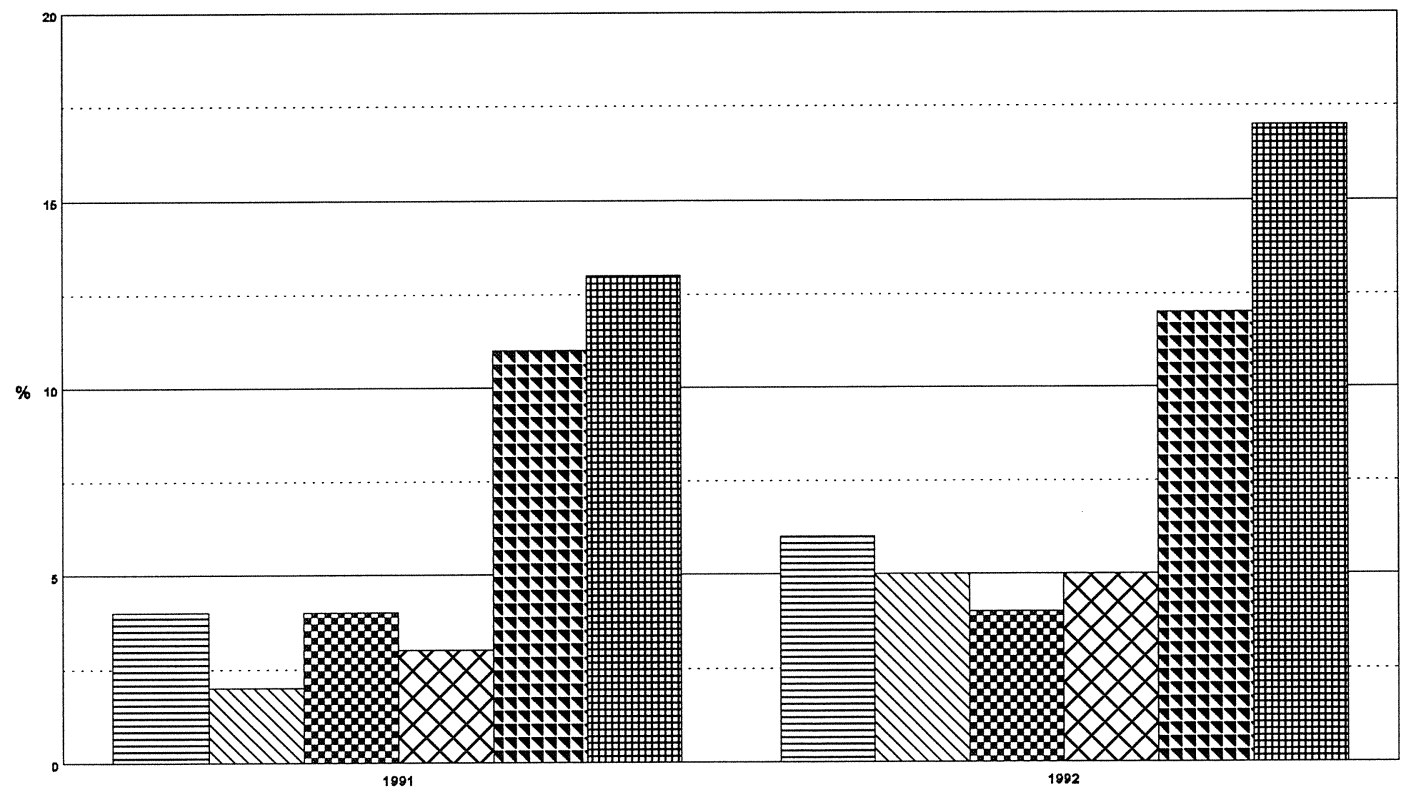

year of leaving schoo

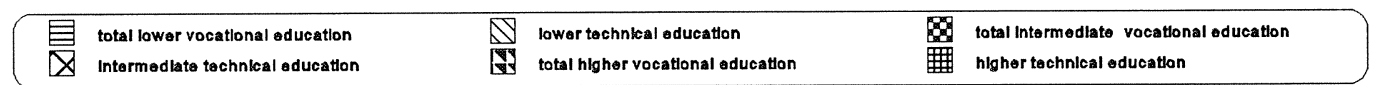

* universities excluded

** excluding drop-outs

Source: HBO-Monitor/RUBS/ROA

However, unemployment alone is not enough to indicate the initial match between school-leavers and the labour market. As the OECD's Employment Outlook 1993 notes, unemployment is only one measure of labour market slack. Labour market mismatches are often also manifest in the form of under-utilization. Under-utilization problems arise when people occupy posts at a lower level than their training has prepared them for, or when the field of their training does not relate at all to their function (Van Dam, Ramaekers and Van der Velde, 1991). 
Graph 3.21

Under-utilization* among Dutch vocational (lower, intermediate and higher**) school-leavers ${ }^{\star \star \star}$ about one year after leaving school, 1991 and 1992

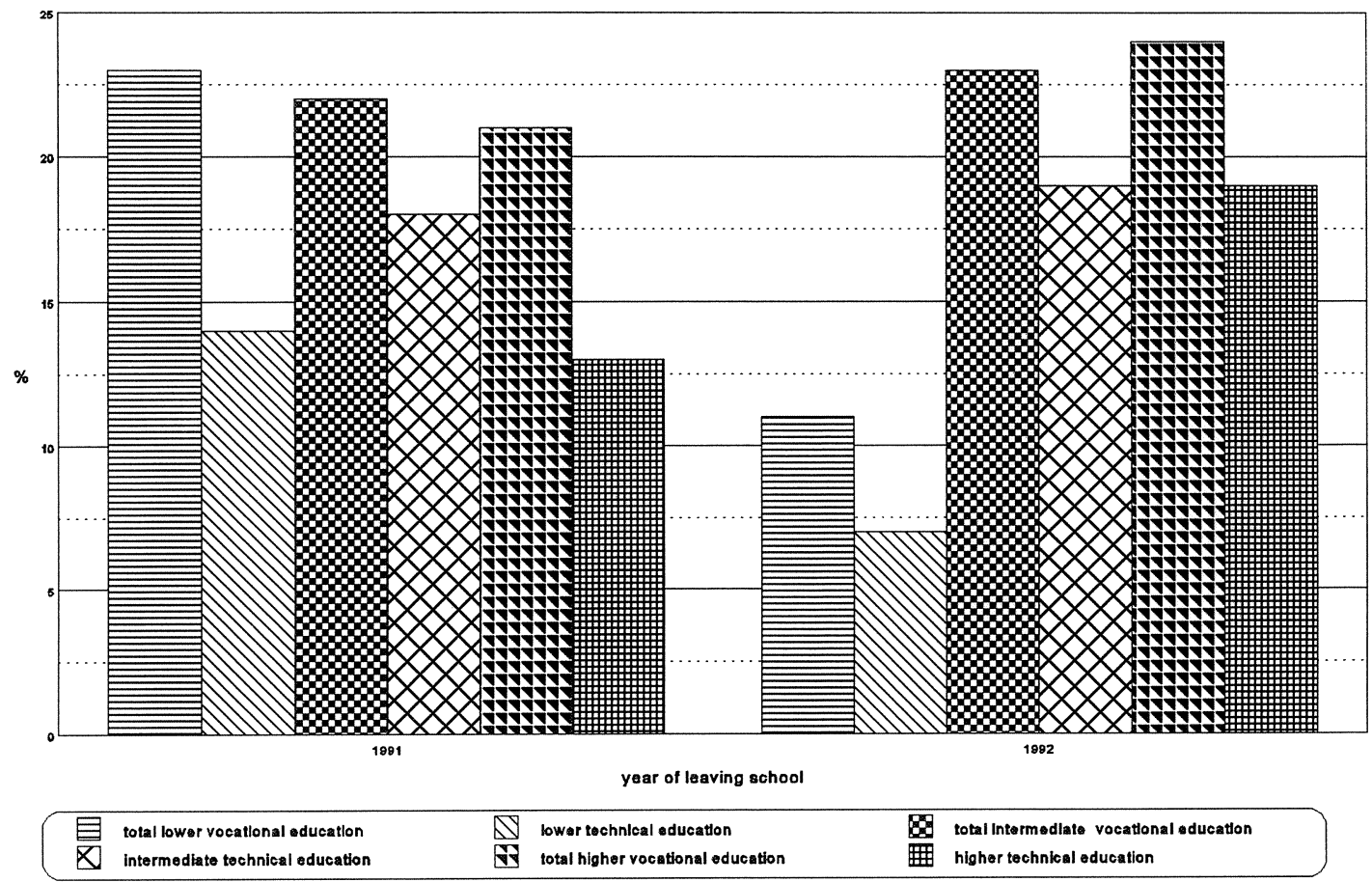

* proportion of paid working school-leavers having jobs below their educational level

** universities excluded

*** excluding drop-outs

Source: HBO-Monitor/RUBS/ROA

Graph 3.21 shows the levels of under-utilization among Dutch school-leavers in vocational education. The graph shows that the rate of under-utilization for those with a technical education is less than the average rate for vocational education as a whole. Thus for all educational levels (except university), school-leavers with a technical background are more likely to find jobs which match the level of their education. Comparing the rates of under-utilization for school-leavers in 1991 and 1992, we can see some remarkable differences. The graph shows that the under-utilization of school-leavers with lower vocational education has strongly decreased, whereas under-utilization among those with higher vocational education has strongly increased. These results indicate an over-supply of people with higher vocational education in the Netherlands, as many school-leavers at this level have to accept a job below their educational level. However, this result may again be due to cyclical sensitivity and the segmented labour market, in which there may only be job openings at relatively low levels for now, but offering the possibility in time of promotion to work at the right educational level (see e.g. De Grip, Heijke and Willems, 1992). The position of those with higher technical education is only slightly better than for higher vocational education as a whole. The rate of under-utilization of those with intermediate vocational education has increased only slightly.

From the above, it can be seen that technically educated school-leavers have a relatively strong labour market position. Compared to other vocationally educated school-leavers, their capacities are less under-utilized. However, unemployment levels for technically educated school-leavers are rising very rapidly and, for the two highest educational levels, already lie well above those of vocational education as a whole. However, technical occupations are more sensitive to cyclical changes (see e.g. ROA, 
1993). However, if this development becomes a trend in the years to come it might indicate that the strong position of technically educated school-leavers is weakening, and in the future their position may well be the same as that of other vocationally educated school-leavers.

This picture can be partly confirmed by ROA's medium-term forecasts of the labour market position of Dutch school-leavers (ROA, 1993). These bi-annual reports include summaries of the labour market prospects for the various types of education. The future labour market prospects for each type of education are determined by means of the indicator of the future labour market situation, defined as the ratio between the expected expansion ${ }^{14}$ and replacement ${ }^{15}$ demand on the one hand, and the expected flows of school-leavers entering the labour market plus the short-term unemployed, on the other (see e.g. Heijke, 1994). The expected labour market situation in the future may manifest itself in the form of unemployment or labour shortages, but also in changes in wage differentials or the degree of underutilization etc.

Table 3.2 shows that the labour market for all school-leavers cannot be expected to be very favourable in the period 1993-1998. The average labour market prospects are reasonable. Only a few types of education have good labour market prospects, including technical studies in higher vocational education and mathematics, and natural science at the university level. For the technical types of education this might seem remarkable in the light of the changes in employment levels given in graph 2.20 , which showed that the expected annual employment growth for technical workers was relatively low. However, this difference can easily be explained by the fact that those with technical education have relatively many switching opportunities, and thus do not depend only on developments within the occupational sector of technical workers. Despite the poor expected employment growth for technically educated workers at the intermediate and lower levels (graph 2.22), there are many job-openings because of a combination of a relatively high replacement demand with a relatively low flow of school-leavers entering the job market.

14. The demand for new workers which is attributable to growth in employment levels. If employment falls, the expansion demand is negative.

15. The demand for new workers attributable to the need to replace workers who retire, suffer employment disabilities or withdraw from the labour market. The replacement demand can also derive from mobility. 
Table 3.2

Expected labour market position by type of education, 1993-1998

type of education

characterization

PRIMARY EDUCATION

Primary education

poor

JUNIOR GENERAL SECONDARY EDUCATION AND

PREPARATORY VOCATIONAL EDUCATION (PVE)

Junior General Secondary Education

PVE Agriculture

PVE Technical

PVE Transport and Harbour

PVE Commerce and Administration

PVE Community Care, Hotel and Catering

PVE Security

reasonable

good

moderate

reasonable

moderate

reasonable

reasonable

SENIOR GENERAL SECONDARY EDUCATION AND

INTERMEDIATE VOCATIONAL EDUCATION (IVE)

Senior General Secondary Education

IVE Agriculture

IVE Non-medical laboratory

IVE Engineering

IVE Transport and Harbour

IVE Medical Laboratory

IVE Nursing and Paramedical services

IVE Commerce and Administration

IVE Administrative, Legal and Fiscal

IVE Social and Cultural

IVE Community Care

IVE Hotel Catering and Hairdressers

IVE Police, Fire and Defense Forces

poor

reasonable

good

moderate

reasonable

good

reasonable

moderate

good

poor

reasonable

moderate

reasonable

HIGHER VOCATIONAL EDUCATION (HVE)

HVE Teacher training

HVE Interpreter and Translator

HVE Agriculture

HVE Non-medical laboratory

HVE Engineering

HVE Transport and Harbour

HVE Medical Laboratory

HVE Nursing and Paramedic

HVE Commerce and Administration

HVE Business Administration Technology

HVE Administrative, Legal and Fiscal

HVE Social and Cultural

HVE Fine Arts

HVE Police, Fire and Defense Forces

reasonable

reasonable

moderate

good

good

good

good

reasonable

reasonable

moderate

reasonable

reasonable

moderate

reasonable

UNIVERSITY EDUCATION (UE)

UE Teacher training

UE Arts

UE Theology

UE Agriculture

UE Mathematics and Natural Sciences

UE Engineering

UE Veterinary and Medical Sciences and Dentistry

UE Pharmacy

UE Economics, Econometrics and Business Administration

UE Law and Public Administration

UE Social Sciences

UE Fine Arts

\author{
reasonable \\ poor \\ good \\ poor \\ good \\ reasonable \\ good \\ good \\ reasonable \\ moderate \\ moderate \\ poor
}

Source: ROA 


\section{Continuing Vocational Training}

To be able to profit from technological developments, the labour force must become more flexible. Apart from the short-term labour market flexibility facilitated by the growth of various forms of atypical employment relations such as part-time work, temporary contracts, etc. (see e.g. Treu, 1992 and De Grip et al., 1994 (forthcoming)), long-term flexibility is also crucial. The main source of this long-term flexibilisation of the labour force is continuing vocational training (see also e.g. Delsen, 1991). According to the 'White Paper' this should be established by creating a system of permanent learning.

Continuing vocational training is an important instrument to adapt the workforce to shifts in the skill requirements due to technological developments. Hence, participation in training is a good indication of the upgrading of employment by means of training policies. Participation in training (graph 4.1) refers to on-the-job training, apprenticeships, dual system training, and other types of training that are combined with a job. ${ }^{16}$ Graph 4.3 refers only to on-the-job training, leaving out vocational training which is part of initial education (apprenticeship etc.). To calculate the indicators, the number of workers in the 15-49 age group who participated in training in the four weeks before the survey has been related to the total population between 15 and 49 years old. These training participation indicators can be interpreted as measures of the openness of the workforce to the diffusion of technological advances.

Graph 4.1 shows that participation in training is very high in the United Kingdom and Denmark in particular. In the United Kingdom, the proportion of the workforce participating in training actually doubled in the period 1984-1992. For most countries we see declining participation rates from 1988 onwards. This seems to indicate that training is more or less related to the business cycle. Since 1992, The Netherlands has taken over third place in the ranking from Germany. However, this may be partly due to the new definition EUROSTAT has used since $1992 .{ }^{17}$ Graph 4.2 shows a tendency for training participation rates in the various EU countries to diverge.

Graph 4.3 refers only to on-the-job training. Remarkably, this graph shows large increases in the participation rates for most countries since 1988. This strongly indicates that the decreases shown in graph 4.1 have been caused by decreasing numbers of apprenticeships ('dual system students'). Again Denmark and the United Kingdom top the ranking, with the Netherlands far behind in third place. The relatively small proportions of workers participating in on-the-job training in the various countries indicate that on-the-job training is not yet a very broadly used tool in the European Union for upgrading the labour force, although a FORCE report (1994) claims that governments in all countries value on-the-job training very highly. The report states that: There is no doubt that continued vocational training (CVT) of employees on the job, matching new requirements and skills, constitutes a growing field in our ever expanding knowledge society. ... Undoubtedly, all governments agree that CVT is high on the priority list. The same is true for both sides of industry. However, the importance attached to on-thejob training differs between Member States. Graph 4.4 shows that, until 1991, a slight diverging tendency could be observed.

16. The 'Labour Force Survey' conducted yearly by Eurostat for the European Union, produces data on the respondents' participation in training during the four weeks preceding the survey. Persons between the ages of 15 and 50 are asked to state what training they were participating in and for what purpose. From this data we can derive the proportion of the potential labour force between the ages of 15 and 50 that participates in training.

17. Since 1992, EUROSTAT has used a new definition of participation in training. This has led to an increase in the numbers recorded as 'unknown' and a decrease in the categories 'other training' and 'on-the-job training'. For Germany, the result was a decrease in the numbers of workers recorded as participating in on-the-job training to $0 \%$. 
Graph 4.1

Participation in training by the labour force aged 15-49, $1984-1992$

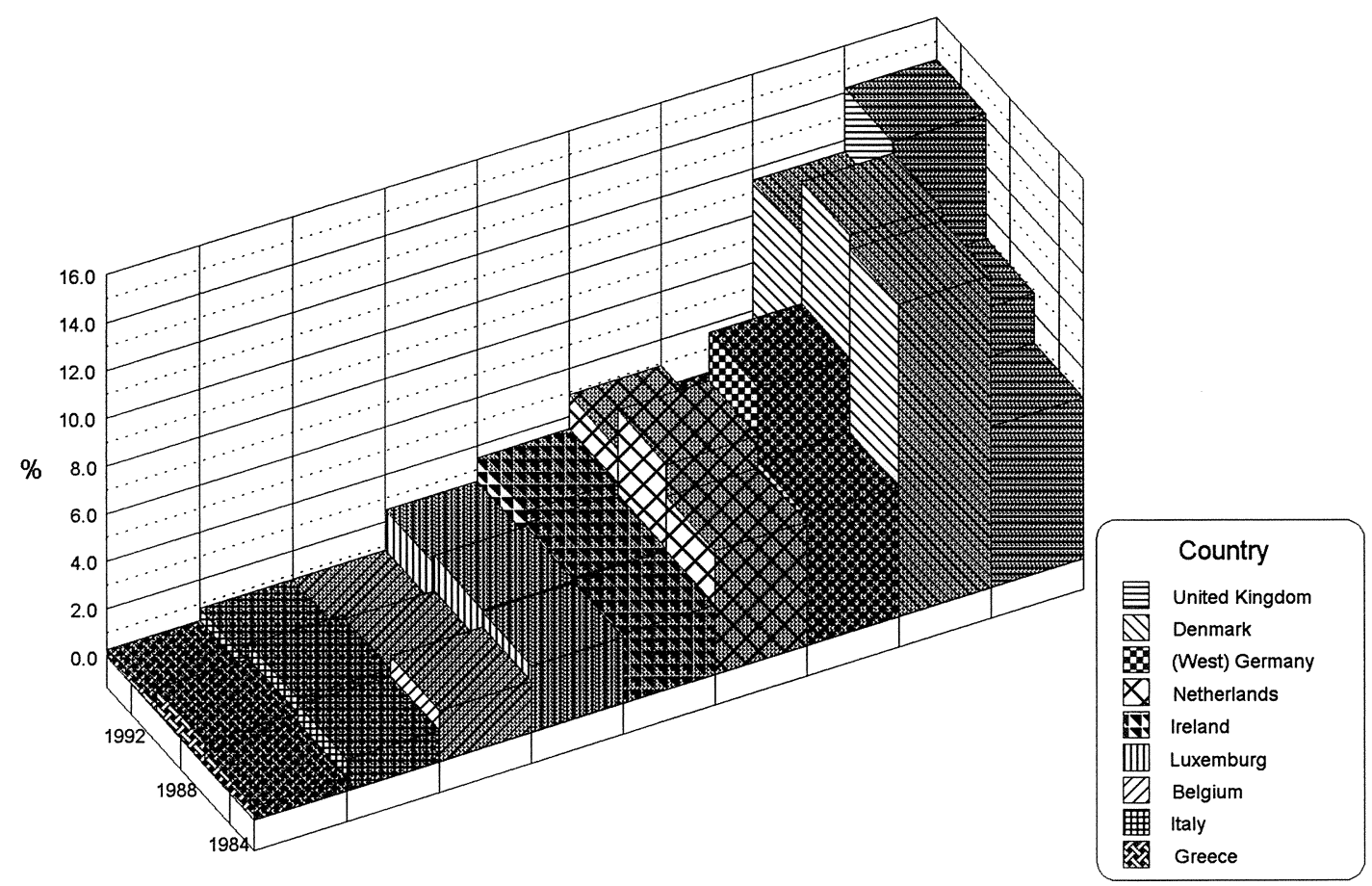

Source: EUROSTAT/ROA

Graph 4.2

Convergence/divergence in participation in training of the labour force aged 15-49, $1983-1992$

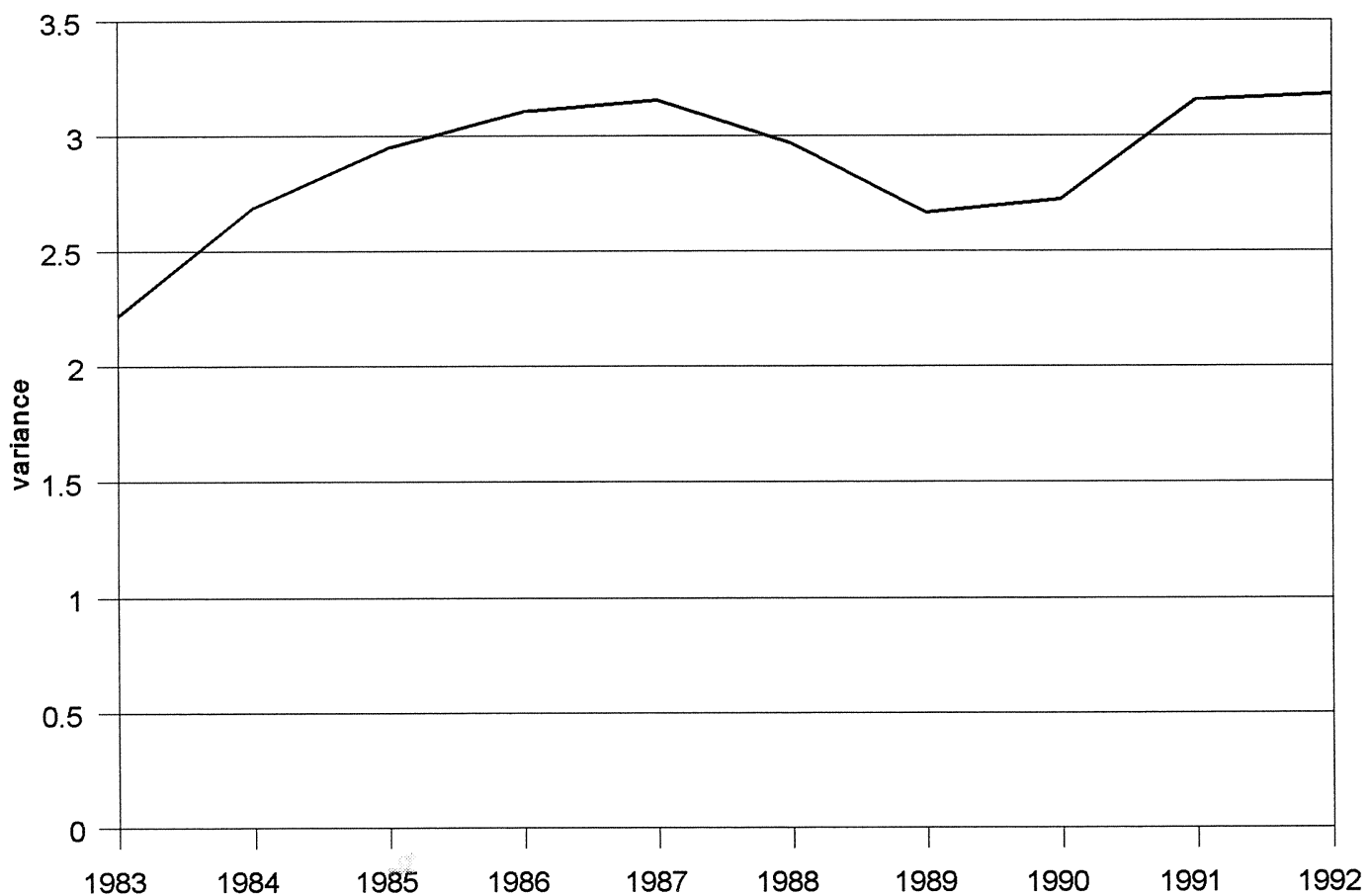

Source: ROA 
Graph 4.3

On-the-job training of the labour force aged 15-49, $1984-1992$

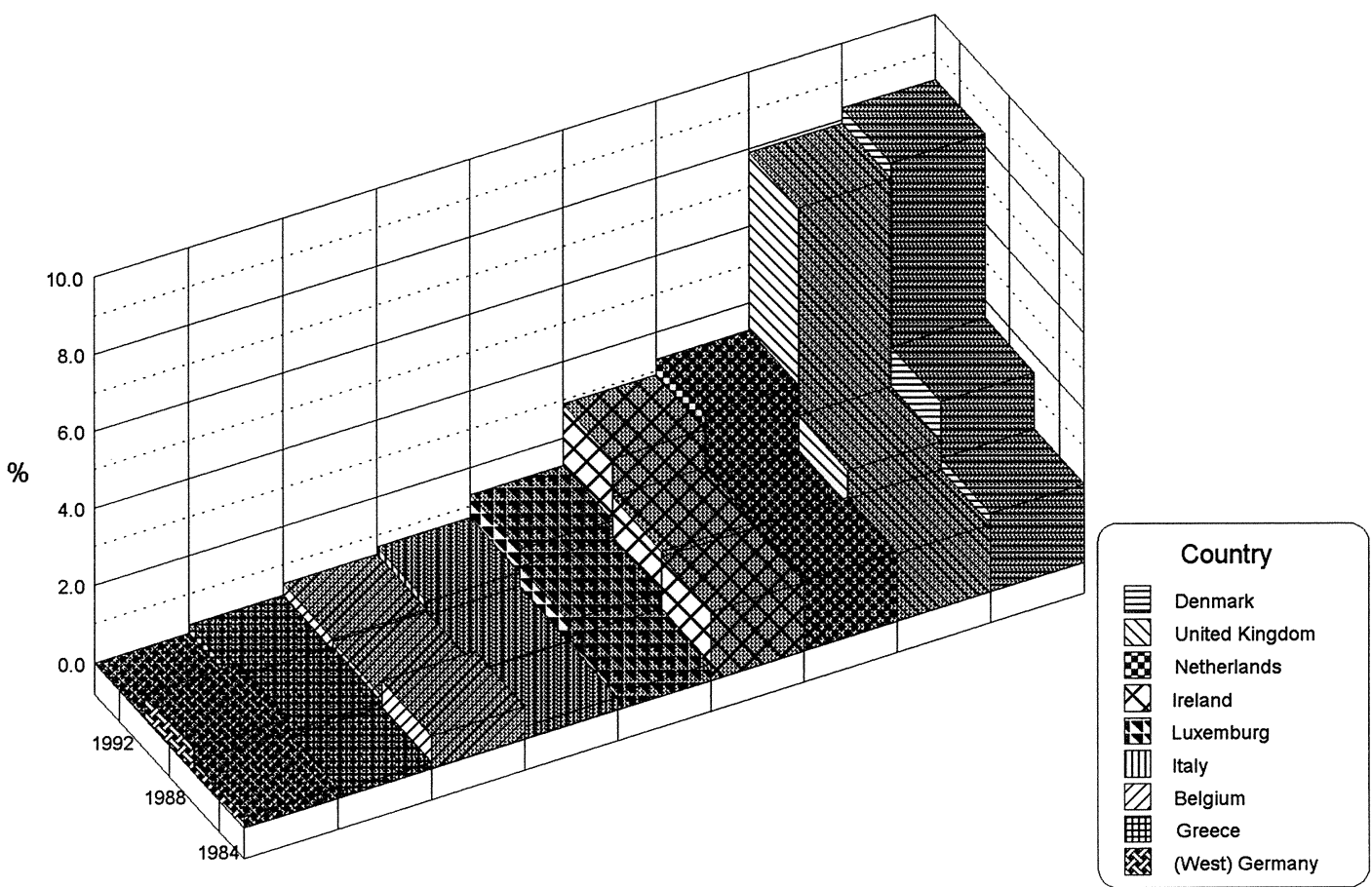

Source: EUROSTAT/ROA

Graph 4.4

Convergence/divergence in on-the-job training of the labour force aged 15-49, $1983-1992$

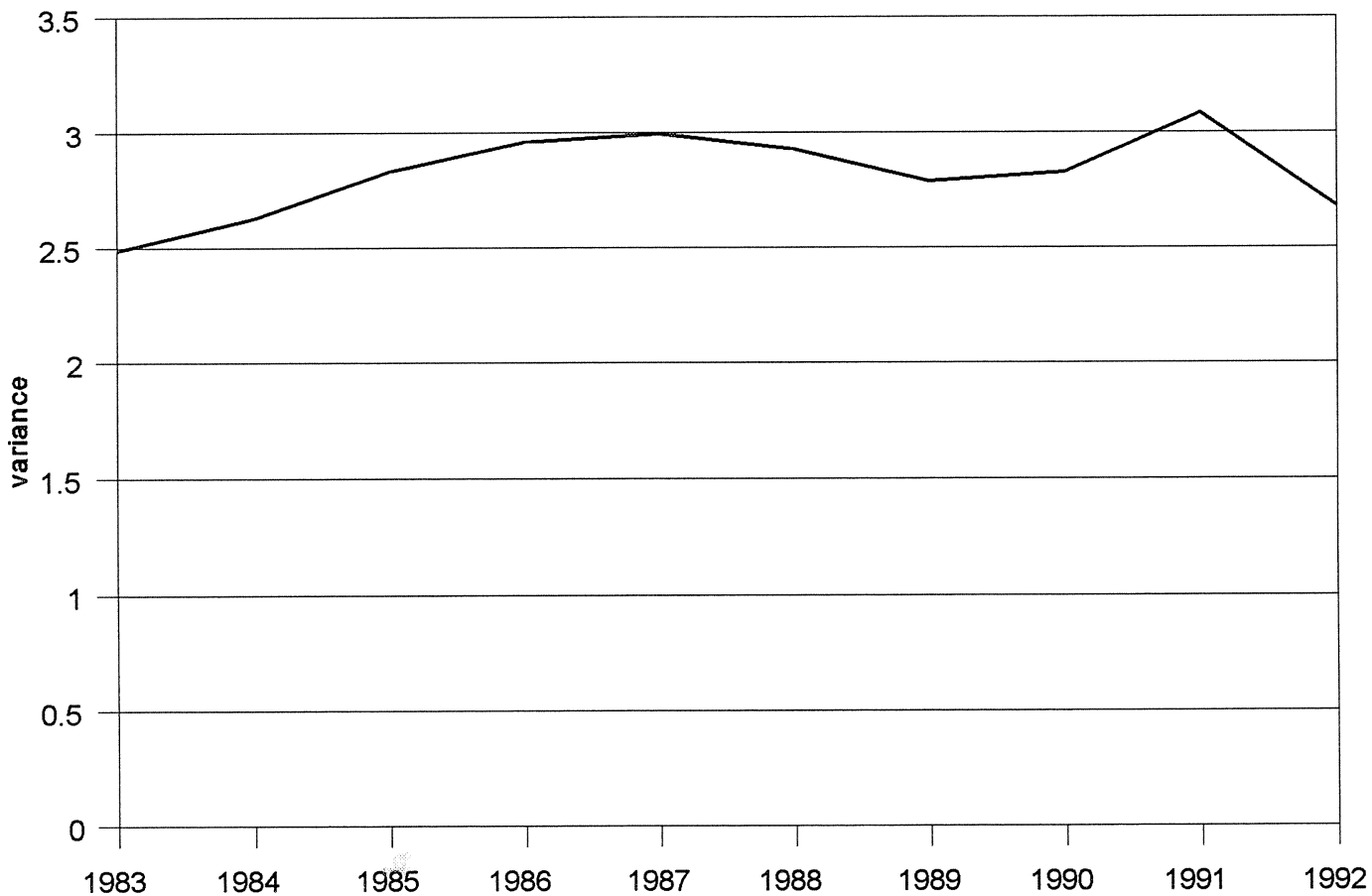

Source: ROA 


\section{Conclusion}

In this report we have tried to give an indication of the potential for technological innovation and diffusion of the Dutch labour force, as measured particularly by investments in the various forms of human capital, and to place these investments and potential in an international perspective. Initial education and continuing vocational training are both important features of the upgrading of the labour force. A high skill level in the labour force is a necessary, though not sufficient, condition for ability to adapt to the skill requirements posed by new technologies and their diffusion.

In chapter 2 we first analyzed the educational level of the workforce. This analysis showed that the educational level of the Dutch labour force is relatively high, compared to the European Union Member States. However, if we take countries such as Sweden, Switzerland and the United States into account, we see that the Netherlands is falling behind.

Unemployment data was also presented (section 2.3), since it indicates both the country's competitive position and the quality of the match between labour supply and demand. In all countries, unemployment levels were lower at higher skill levels. Of the countries presented, the Netherlands has one of the lowest unemployment rates. Only Sweden and Switzerland, the traditional low unemployment countries, had unemployment rates of close to $2 \%$, but these two countries also showed large increases in unemployment from 1989 to 1991 . In the Netherlands, unemployment was lowest among technically educated workers.

We also presented some projections of changes in the labour market, differentiated by broad occupational sectors, in some OECD countries. Although the various forecasts were not fully comparable, they all indicated large increases in employment for professionals and managers, in particular. These two occupational sectors have the largest proportion of highly-skilled workers. This is a strong indication of the importance of upgrading the skill level of new entrants to the labour market, or increasing the skill level of the current workforce by continuing vocational training. For the Netherlands, remarkably, the occupational sectors of cultural and medical workers showed the largest expected annual employment growth. Further analysis with regard to the educational categories for the Netherlands showed that the largest annual employment growth is expected for the intermediate and, especially, the higher educational categories. Those with higher technical and commercial education had the highest projected annual growth. ${ }^{18}$ This relatively good labour market position for higher technical education is also reflected in the second lowest unemployment rate for this educational category in 1992, at approximately $3.5 \%$.

The indicator of the demographic conditions for adaptability showed that in most countries the proportion of young people in the total population is rather low. Only the United States and the Netherlands had values that indicate relatively high proportions of young people, although the rate in Netherlands showed a clear downward trend. In general it can be concluded that the adaptability of the future labour force will decline as a result of declining numbers of young people entering the labour market. This is a further strong pointer towards the increasingly important role of continuing vocational education, to keep the workforce flexible enough to adapt to the skill requirements due to technological developments.

18. Although the results for the occupational sectors seemed to contradict the results for the educational categories, this can easily be explained from the fact that we are comparing growth statistics and not absolute numbers. For example an annual growth figure of $1.8 \%$ for cultural workers only means an absolute increase in employment of 1,400 whereas an annual growth figure of $0.7 \%$ for commercial workers is equal to an increase in employment of 13,300 . If we relate this absolute number to the number of commercially educated leaving higher education it can be seen that his means a large employment growth for this group. 
The indicator of the skill level flexibility of the Dutch population showed an enormous increase in the proportions of people with university and lower general secondary education in the Dutch labour force. The indicator also showed two threats to the flexibility of the Dutch labour force. First, we could see a rising proportion of school-leavers with only primary education, and a rise in the proportion of the Dutch labour force with only these skills. This group will find it difficult to keep up with technological development. Secondly, the proportion of school-leavers with intermediate vocational education is very low. This may indicate that this skill category, which is very important in the diffusion process, will diminish in the future.

Chapter 3 presented various indicators with regard to initial education. The Netherlands had the second highest public expenditure on education, as a percentage of real GDP, but also had the largest decrease in public spending on education. Remarkably, public expenditure on initial education per student in the Netherlands is relatively low (section 3.2). A strong diverging trend could be observed among the countries in the sample on this measure.

Higher education was also analyzed separately (section 3.3), as those with higher education fulfil an especially important role in both diffusion processes and adaption to technological innovations. Expenditures per student were high in the United States, with the Netherlands having the second highest expenditure per student. Within university education, the percentage of degrees awarded in sciences ranged from 15\% (United States) to $35 \%$ (Germany). The Netherlands has a below average position, with about 1 out of 4 students receiving a degree in one of the sciences. For a few countries this analysis could be further differentiated into three main scientific fields. The Netherlands has a bad position in the field of mathematics and computer science, and can be expected to fall behind in the other scientific fields as well, since the proportions of all degrees being awarded in both natural science and engineering are decreasing markedly.

Using a very broad definition of vocational education, we saw in section 3.4 that the Netherlands was leading the ranking. The good position of the Netherlands was largely caused by the large proportion of students in higher education. But this still indicates that the flexibility produced by the Dutch educational system is rather high, as many students are either vocationally trained (in the narrow sense), or have received higher education, both of which are important determinants of adaptability in the face of technological change and the diffusion of new technologies.

The rate of participation in dual education in the Netherlands is far below that in Denmark and (West) Germany, and also below the level in France and the United Kingdom. Moreover, the Netherlands cannot be expected to catch up with the other countries in the near future, as we saw that, after the successful 'doubling operation' of the mid-eighties, apprenticeship numbers dropped markedly in the early nineties. A scenario study of the developments until the year 2001 has shown that, unless strong measures are implemented, there will be a large shortage of apprentices in almost all sectors. The first indications of decreasing numbers of primary apprentices (measured by their contribution to sectoral labour volume) were already apparent in most industrial sectors in 1992. This was not yet the case for secondary apprenticeships in 1992, but developments here indicate that shortages of secondary apprentices may also become apparent in the near future.

Reasons for the decline in the number of apprenticeships in the Netherlands can be found in demographic developments, a tendency among students to have longer 'careers' in full-time education, high drop-out rates, and the bad image of technical work among students in secondary education. Technical jobs are often associated with heavy, boring and dirty work. This doesn't make it very attractive to students to chose a technical course of study. As a result, only $44 \%$ of boys and $6 \%$ of girls 
choose a technological study or technical occupation. If future mismatches between educational supply and demand for newcomers in this field are to be avoided, it would seem wise to improve the image of technology in general and technical work in particular.

Unemployment levels among Dutch school-leavers also indicate a mismatch between demand and supply in the Netherlands. The unemployment rates of school-leavers with higher technical education are even higher than those of all school-leavers from higher vocational education. However, as we only had two years of data available, and as the demand for technically educated workers is more cyclically sensitive than for other kinds of vocationally educated workers, the higher unemployment rates of technically educated school-leavers may well be temporary. Moreover, it could also be seen that technically educated school-leavers more often find jobs at their own skill level. ROA's projections partly confirm the good labour market prospects of technically educated school-leavers, since the labour market prospects to 1998 for most intermediate and higher technical types of education are reasonable to good.

Finally, continuing vocational education was analyzed in chapter 4 . If new technologies are to be rapidly diffused, not only must new entrants to the labour market have the capacities to implement them, the current workforce must also learn to work with the new technologies. As the 'White Paper' has already noted, it is very important to establish a system of permanent learning. On-the-job training, in particular, is increasing in importance in most European Union countries. Although there are still very large differences between countries, which are not becoming smaller, it is clear that most countries are aware of the importance of continuing vocational education. Denmark and the United Kingdom, in particular, had high levels of on-the-job training, with the Netherlands far behind in third place.

Overall, it can be concluded that the breeding grounds for technological innovation and the diffusion of technologies in the Netherlands must receive a mixed report, based on an international comparison. The labour force in the Netherlands is educated relatively highly, as compared to the other members of the European Union, but the skill level is falling behind that in countries such as Sweden, Switzerland and the United States. On the other hand, the Netherlands still has a relatively large proportion of students following vocational education, broadly defined, and especially higher education, which indicates that the adaptability of the labour force to shifts in skill requirements, due to technological developments, is rather high. But in intermediate vocational education and university science studies, in particular, the Netherlands is rapidly losing ground. The Netherlands is also expected to face large shortages of apprentices. Thus adaptability to technological change in the Netherlands can be expected to decrease in the future.

It is the Dutch ambition to become a knowledge intensive country. It will therefore be very important to improve the image of technical jobs and education, so as to be able to maintain international competitiveness by maintaining high technological standards and developing highly innovative industries. 


\section{References}

Adviescommissie inzake de voortgang van het Industriebeleid (1983), Verslag van werkzaamheden 2, 's-Gravenhage.

Arbeidsvoorziening (1993), Schoolverlatersbrief 1993, Rijswijk.

Bartel, A.P., F.R. Lichtenberg (1987), The comparative advantage of educated workers in implementing new technology, The Review of Economics and Statistics, Number 1, 1987, pp. 1-11.

Braverman, H. (1974), Labor and Monopoly Capital: The degradation of Work in the Twentieth Century, Monthly Review Press, New York/London.

CBS $\left(^{*}\right)$, Volwasseneneducatie. Beroepsbegeleidend onderwijs en vormingswerk, cursorisch ondernemersonderwijs, Voorburg/Heerlen.

CBS $\left(^{*}\right)$, Speur- en ontwikkelingswerk in Nederland, Voorburg/Heerlen.

Centraal Planbureau (*), Centraal economisch plan, SDU-uitgeverij, Den Haag.

Centraal Planbureau (1992), Nederland in drievoud. Een scenariostudie van de Nederlandse economie 1990-2015, SDUuitgeverij, Den Haag.

Commissie van de Europese Gemeenschappen (1993), Groei, concurrentie, werkgelegenheid: Naar de 21e eeuw: wegen en uitdagingen: Witboek, Bulletin van de Europese Gemeenschappen, supplement 6/1993.

Daly, A. (1986), Education and Productivity, A comparison of Great Britain and the United States, British Journal of Industrial Relations, Vol. 24, pp. 251-266.

Dam, J.W. van, G.W.M. Ramaekers, R.K.W. van der Velden (1991), Skill shortages in Limburg, ROA-R-1991/3E, Maastricht.

Dam, J.W. van, A. de Grip (1990), Technology Indicators: Population, Labour and Schooling, ROA-R-1990/5E, Maastricht.

Delsen, L. (1991), Atypical employment relations and government policy in Europe, Labour, Vol. 5, pp. 647-660.

European Round Table of Industrialists (1989), Education and European Competence, European Round Table of Industrialists, Brussels.

EUROSTAT (*), Labour force survey, Luxembourg.

FORCE (1994) (Blanpain, R., C. Engels, and C. Pellegrini, editors), Contractual policies concerning continued vocational training in the European Community member states, Peeters Press, Leuven.

Grip, A. de, J. Hoevenberg, E. Willems, Atypical Employment Relations by Occupational sector in the European Union, forthcoming.

Grip, A. de, J. Hoevenberg (1994), Upgrading in the European Union, paper presented at the EALE conference.

Grip, A. de, H. Berendsen, L. Borghans, R.J.P. Dekker (1993), Toekomstverkenning leerlingwezen, ROA-R-1993/4, Maastricht.

Grip, A. de, J.A.M. Heijke, E.J.T.A. Willems (1992), The costs of not training. Contribution for the Netherlands, ROA-W1992/7E, Maastricht.

Groot, L.F.M., A. de Grip (1991), Technological change and skill formation in the bank sector, Economics of Education Review, Vol. 10, pp. 57-71.

Heijke, J.A.M. (editor) (1994), Forecasting the labour market by occupation and education, Kluwer Academic Publishers, Boston/Dordrecht/London.

Hoevenberg, J., A. de Grip (1994), Indicators of occupational employment in the European Union, ROA-R-1994/3E, Maastricht.

ILO (*), Yearbook of labour statistics, Geneva.

Loo, P.J.E. van de, R. van der Velden, M.H. Wieling (1993), De arbeidsmarktpositie van afgestudeerden van het hoger beroepsonderwijs; HBO-Monitor 1992, Voorlichtingsdienst HBO-Raad, 's-Gravenhage.

Loo, P.J.E. van de, R. van der Velden (1994), De arbeidsmarktpositie van afgestudeerden van het hoger beroepsonderwijs; HBO-Monitor 1993, Voorlichtingsdienst HBO-Raad, 's-Gravenhage.

Marsden, D., P. Ryan (ed.) (1991), Initial Training, Labour Market Structure and Public Policy: Intermediate Skills in British and German Industry, International Comparisons of Vocational Education and Training for Intermediate Skills, Falmer Press, London.

Meijer, J.M. (1994), Uitval uit leerlingwezen en kort-middelbaar beroepsonderwijs. Een overzicht van onderzoeken naar uitval en rendement, LOWWJ, Utrecht.

Ministerie van Onderwijs en Wetenschappen (1993), Referentieraming 1993; methodiek en tabellen, Zoetermeer.

OECD $\left(^{*}\right)$, Education at a glance. OECD indicators, Paris.

OECD $\left({ }^{*}\right)$, Labour force statistics, Paris.

OECD (1992), Public educational expenditure, costs and financing: an analysis of trends 1970-1988, Paris.

OECD (1993), Education in OECD countries: a compendium of statistical information, 1988/89 - 1989/90, Paris.

OECD (1994), Employment outlook, July 1994, Paris.

ROA (1993), The labour market by education and occupation to 1998, ROA-R-1993/10E, Maastricht. 
Rumberger, R.W., H.M. Levin (1989), Schooling for the modern workplace, in: Investing in People: A Strategy for addressing America's Workforce Crisis: Background Paper, Commission on Workforce Quality and Labor Market Efficiency, U.S. Department of Labor, Washington D.C., Vol. 1, pp. 85-114.

Ryan, P. (1991), International comparisons of vocational education and training for intermediate skills, The Falmer Press, New York.

SER (1994), Sociaal-economisch beleid 1994-1998, publikatienummer 94/03, Den Haag.

Smoorenburg, M.S.M. van, R.K.W. van der Velden, P.J.E. van de Loo, M.H. Wieling (1994), Schoolverlaters op de arbeidsmarkt; de uitstroom en bestemming van het schooljaar 1991-1992, Stichting Landelijk Dienstverlenend Centrum voor Studie- en Beroepskeuzevoorlichting, Leeuwarden.

Spenner, K.I. (1985), The upgrading and downgrading of occupations: Issues, evidence and implications for education, Review of Educational Research, vol. 55, pp. 125-154.

Treu, T. (1992), Labour flexibility in Europe, International Labour Review, Vol. 131, pp. 497-512.

UNESCO $(*)$, Statistical yearbook, Paris.

U.S. Department of Labor, Commission on Workforce Quality and Labor Market Efficiency (1989), Investing in People: $A$ Strategy for Addressing America's Workforce Crisis, United States P.. Office, Washington D.C.

Wieling, M.H., R.K.W. van der Velden, P.J.E. van de Loo (1993), Schoolverlaters op de arbeidsmarkt; de uitstroom en bestemming van het schooljaar 1990-1991, Stichting Landelijk Dienstverlenend Centrum voor Studie- en Beroepskeuzevoorlichting, Leeuwarden.

Willems, E.J.T.A., A. de Grip, Toekomst in techniek? Waarde-oriëntatie beeldvorming en keuze-intenties van jongeren, ROA-R-1993/7.

$\left(^{*}\right)=$ several annually updated versions used. 


\section{Appendix}

Table A2.1

Population aged 25-64 by highest completed level of education (ISCED 1-digit classification)

\begin{tabular}{|c|c|c|c|c|}
\hline & $\underset{\%}{\text { ISCED }} 0 / 1 / 2$ & $\begin{array}{c}\text { ISCED } 3 \\
\%\end{array}$ & $\begin{array}{c}\text { ISCED } 5 \\
\%\end{array}$ & $\underset{\%}{\text { ISCED } 6 / 7}$ \\
\hline $\begin{array}{l}1991 \\
\text { Austria } \\
\text { Denmark } \\
\text { France } \\
\text { Germany } \\
\text { Netherlands } \\
\text { Sweden } \\
\text { Switzerland } \\
\text { United Kingdom } \\
\text { United States }\end{array}$ & $\begin{array}{l}32.7 \\
38.5 \\
49.5 \\
18.2 \\
43.8 \\
30.9 \\
19.3 \\
34.7 \\
16.7\end{array}$ & $\begin{array}{l}60.6 \\
43.2 \\
35.4 \\
60.1 \\
36.7 \\
43.9 \\
60.4 \\
49.0 \\
46.8\end{array}$ & $\begin{array}{r}-X- \\
5.6 \\
5.4 \\
10.6 \\
13.4 \\
12.2 \\
13.2 \\
6.7 \\
12.8\end{array}$ & $\begin{array}{r}6.7 \\
12.7 \\
9.7 \\
11.2 \\
6.2 \\
13.0 \\
7.0 \\
9.6 \\
23.6\end{array}$ \\
\hline $\begin{array}{l}1989 \\
\text { Austria } \\
\text { Denmark* } \\
\text { France } \\
\text { Germany } \\
\text { Netherlands** } \\
\text { Sweden } \\
\text { Switzerland } \\
\text { United Kingdom } \\
\text { United States }\end{array}$ & $\begin{array}{l}35.1 \\
43.0 \\
50.2 \\
21.6 \\
45.1 \\
32.7 \\
20.0 \\
36.6 \\
18.1\end{array}$ & $\begin{array}{l}59.7 \\
40.0 \\
33.2 \\
61.0 \\
35.5 \\
43.7 \\
50.4 \\
47.2 \\
46.0\end{array}$ & $\begin{array}{r}-X- \\
7.0 \\
6.6 \\
7.2 \\
13.2 \\
10.8 \\
14.7 \\
6.5 \\
12.5\end{array}$ & $\begin{array}{r}6.4 \\
10.0 \\
6.7 \\
10.2 \\
5.8 \\
12.4 \\
9.4 \\
8.8 \\
23.4\end{array}$ \\
\hline $\begin{array}{ll}\text { * } & 1988 \\
\text { ** } & 1990 \\
X & \text { included in IS }\end{array}$ & & & & \\
\hline
\end{tabular}

Source: OECD, Education at a Glance

Table A2.4

Employment shares of intermediate skilled workers by occupational sectors in 1991

\begin{tabular}{|c|c|c|c|c|c|c|c|c|}
\hline & $\begin{array}{c}\text { professional } \\
\text { workers } \\
\%\end{array}$ & $\begin{array}{c}\text { managerial } \\
\text { workers } \\
\%\end{array}$ & $\begin{array}{c}\text { clerical } \\
\text { workers } \\
\%\end{array}$ & $\begin{array}{c}\text { sales } \\
\text { workers } \\
\%\end{array}$ & $\begin{array}{c}\text { service } \\
\text { workers } \\
\%\end{array}$ & $\begin{array}{c}\text { agricultural } \\
\text { workers } \\
\%\end{array}$ & $\begin{array}{c}\text { production } \\
\text { workers } \\
\%\end{array}$ & $\begin{array}{c}\text { total } \\
\%\end{array}$ \\
\hline Belgium & 18.8 & 35.3 & 48.2 & 36.5 & 29.0 & 19.5 & 25.1 & 30.0 \\
\hline Germany & 31.9 & 45.2 & 69.3 & 68.1 & 53.1 & 46.3 & 59.9 & 55.9 \\
\hline Denmark & 32.4 & 53.1 & 68.6 & 64.7 & 42.9 & 44.8 & 52.4 & 49.7 \\
\hline Ireland & 17.9 & 38.7 & 62.5 & 44.4 & 33.0 & 16.8 & 22.2 & 31.4 \\
\hline Netherlands & 34.6 & 41.9 & 52.5 & 44.9 & 43.0 & 41.6 & 38.7 & 41.8 \\
\hline United Kingdom & 17.8 & 23.8 & 18.9 & 17.4 & 16.4 & 17.2 & 24.2 & 20.0 \\
\hline European Union & 24.5 & 33.7 & 47.5 & 37.6 & 28.4 & 17.2 & 35.0 & 33.9 \\
\hline
\end{tabular}

Source: EUROSTAT/ROA 
Table A2.5

Employment shares of highly-skilled workers by occupational sectors in 1991

\begin{tabular}{lcccccccc}
\hline & $\begin{array}{c}\text { professional } \\
\text { workers } \\
\%\end{array}$ & $\begin{array}{c}\text { managerial } \\
\text { workers } \\
\%\end{array}$ & $\begin{array}{c}\text { clerical } \\
\text { workers } \\
\%\end{array}$ & $\begin{array}{c}\text { sales } \\
\text { workers } \\
\%\end{array}$ & $\begin{array}{c}\text { service } \\
\text { workers } \\
\%\end{array}$ & $\begin{array}{c}\text { agricultural } \\
\text { workers } \\
\%\end{array}$ & $\begin{array}{c}\text { production } \\
\text { workers } \\
\%\end{array}$ & $\begin{array}{c}\text { total } \\
\%\end{array}$ \\
\hline Belgium & 75.0 & 38.3 & 20.9 & 19.2 & 4.6 & 3.5 & 3.3 & 26.0 \\
Germany & 55.0 & 43.7 & 10.3 & 9.1 & 7.6 & 12.0 & 8.7 & 18.8 \\
Denmark & 54.4 & 32.1 & 12.1 & 6.9 & 5.4 & 3.8 & 4.8 & 20.4 \\
Ireland & 75.1 & 44.3 & 15.2 & 11.7 & 9.4 & 6.2 & 5.5 & 21.1 \\
Netherlands & 59.3 & 44.1 & 15.1 & 8.5 & 3.6 & 2.4 & 2.5 & 21.3 \\
United Kingdom & 57.4 & 29.6 & 6.3 & 8.2 & 4.3 & 3.6 & 3.3 & 16.0 \\
European Union & 60.6 & 36.2 & 10.7 & 8.3 & 4.7 & 3.5 & 4.8 & 17.1 \\
\hline
\end{tabular}

Source: EUROSTAT/ROA

Table A2.6-2.10

Unemployment in the workforce aged $25-64$, by educational level (ISCED)

\begin{tabular}{|c|c|c|c|c|c|c|}
\hline & $\underset{\%}{\text { ISCED }} 0 / 1 / 2$ & $\underset{\%}{\text { ISCED } 2}$ & $\begin{array}{c}\text { ISCED } 3 \\
\%\end{array}$ & $\underset{\%}{\text { ISCED }} 5$ & $\begin{array}{c}\text { ISCED } 6 / 7 \\
\%\end{array}$ & $\begin{array}{c}\text { Total } \\
\%\end{array}$ \\
\hline \multicolumn{7}{|l|}{1991} \\
\hline Denmark & -- & 14.2 & 9.1 & 5.7 & 4.6 & 9.9 \\
\hline France & 9.0 & 11.5 & 6.6 & 3.6 & 3.8 & 7.8 \\
\hline Germany & -- & 10.5 & 6.6 & 4.6 & 4.5 & 6.6 \\
\hline Netherlands & 13.0 & 6.7 & 4.9 & 4.0 & 4.6 & 6.1 \\
\hline Sweden & -- & 2.6 & 2.3 & 1.1 & 1.1 & 2.1 \\
\hline Switzerland & -- & 1.3 & 1.5 & 0.8 & 2.2 & 1.4 \\
\hline United Kingdom & -- & 10.4 & 6.5 & 3.7 & 3.1 & 7.1 \\
\hline United States & 11.8 & 12.8 & 7.3 & 5.6 & 3.6 & 6.8 \\
\hline \multicolumn{7}{|l|}{1989} \\
\hline Denmark* & -- & 12.2 & 7.1 & 4.0 & 3.4 & 8.3 \\
\hline France & 11.8 & 10.5 & 6.6 & 3.4 & 3.0 & 8.1 \\
\hline Germany & - & 13.8 & 6.8 & 3.7 & 4.5 & 7.3 \\
\hline Netherlands ${ }^{\star *}$ & 13.6 & 7.6 & 4.8 & 4.6 & 5.0 & 6.5 \\
\hline Sweden & -- & 1.4 & 1.1 & 0.9 & 0.8 & 1.1 \\
\hline Switzerland & -- & 1.6 & 0.6 & 0.3 & 0.8 & 0.8 \\
\hline United Kingdom & -- & 9.8 & 5.7 & 2.7 & 2.4 & 6.4 \\
\hline United States & 8.5 & 9.1 & 4.6 & 3.3 & 2.2 & 4.4 \\
\hline \multicolumn{7}{|c|}{ * The unemployment rate for Denmark actually refers to 1988 . } \\
\hline
\end{tabular}

Source: EUROSTAT/ROA 
Table A2.11

Unemployment ('Unemployed Workforce') per educational category, 1992

\begin{tabular}{ll}
\hline Educational category & $\%$
\end{tabular}

Primary Education

Junior General Secondary Education /

Preparatory Vocational Education

- general/commerce

10.1

- technical/agricultural

- community care

Intermediate level

- general

- technical/agricultural

- commerce

- community care

Higher level

- technical/agricultural

- commerce

- arts and community services

Total (incl. other educational categories and education not known

Source: Arbeidsvoorziening (1993)

Table A2.12a+b

Unemployment by educational sector in 1993 for the population aged 15-64 and for the population aged 15-24

\begin{tabular}{lcc}
\hline & $15-64$ & $15-24$ \\
Educational sector & $\%$ & $\%$ \\
\hline & & 27.5 \\
Primary Education & 15.6 & 13.8 \\
Junior General Secondary Education & 10.3 & 11.1 \\
Preparatory Vocational Education & 8.4 & 15.2 \\
General Higher Secondary Education & 12.2 & 7.1 \\
Vocational Higher Secondary Education & 5.2 & 10.3 \\
Higher Vocational Education & 5.1 & - \\
University Education & 6.1 & 11.8 \\
Total (incl. other educational categories and education not known & 7.5 &
\end{tabular}

Source: CBS 
Table A2.19

Employment by occupational sectors, 1992

\begin{tabular}{lrr} 
occupational sector & numbers working & \% of total employment \\
\hline Educational occupations & 308,000 & 5.6 \\
Cultural occupations & 78,000 & 1.4 \\
Agricultural occupations & 249,000 & 4.5 \\
Technical and industrial occupations & $1,496,000$ & 27.1 \\
Transport occupations & 329,000 & 6.0 \\
Medical and paramedical occupations & 388,000 & 7.0 \\
Commercial and administrative occupations & $1,895,000$ & 34.3 \\
Socio-cultural occupations & 187,000 & 3.4 \\
Hotel catering and services occupations & 490,000 & 1.9 \\
Public security and safety occupations & 103,000 & 1.9 \\
Total (incl. occupation not known) & & 100
\end{tabular}

Source: CBS/ROA

Table A2.20a $+b$

Changes in employment by occupational sectors, 1988-1992, and expected developments, 1993-1998 (average annual growth)

\begin{tabular}{lcc}
\hline & $\begin{array}{c}1988-1992 \\
\%\end{array}$ & $\begin{array}{c}1993-1998 \\
\%\end{array}$ \\
occupational sector & & -0.2 \\
\hline Educational occupations & 0.6 & 1.8 \\
Cultural occupations & 0.5 & -0.2 \\
Agricultural occupations & -2.0 & 0.3 \\
Technical and industrial occupations & 0.4 & 1.0 \\
Transport occupations & 0.9 & 1.2 \\
Medical and paramedical occupations & 2.3 & 0.7 \\
Commercial and administrative occupations & 1.9 & 0.8 \\
Socio-cultural occupations & 2.7 & 0.6 \\
Hotel catering and services occupations & 1.6 & 0.6 \\
Public security and safety occupations & 0.8 & 0.7 \\
Total (incl. occupation not known) & 1.6 & \\
\end{tabular}

Source: CBS/ROA 
Table A2.21

Employment by educational categories, 1992

\begin{tabular}{llr}
\hline educational category & numbers working & \% of total employment \\
\hline Primary Education & 563,000 & 9.8 \\
Junior General Secondary Education I & & 9.2 \\
Preparatory Vocational Education & 531,000 & 11.0 \\
- general/commerce & 632,000 & 3.7 \\
- technical/agricultural & 213,000 & 5.2 \\
- community care & & 15.1 \\
Intermediate level & 301,000 & 12.4 \\
- general & 869,000 & 10.3 \\
- technical/agricultural commerce & 715,000 & 5.1 \\
- community care & 594,000 & 5.7 \\
Higher level & & 12.5 \\
- technical/agricultural & 292,000 & 100 \\
- commerce & 327,000 & \\
- arts and community services & 717,000 & \\
Total (incl. other educational categories and & & \\
education not known & $5,844,000$ & \\
\hline
\end{tabular}

Source: CBS/ROA

Table A2.22a $+b$

Changes in employment by educational categories, 1990-1992, and expected developments, 1993-1998 (average annual growth)

\begin{tabular}{lcc}
\hline & $\begin{array}{c}1988-1992 \\
\%\end{array}$ & $\begin{array}{c}1993-1998 \\
\%\end{array}$ \\
educational category & -4.2 & -2.2 \\
\hline Primary Education & & -0.6 \\
Junior General Secondary Education / & & -0.5 \\
Preparatory Vocational Education & 0.0 & -0.1 \\
- general/commerce & -1.0 & 1.0 \\
- technical/agricultural & -0.2 & 1.1 \\
- community care & & 0.9 \\
Intermediate level & 8.4 & 1.6 \\
- general & 2.2 & 2.7 \\
- technical/agricultural & 1.9 & 2.9 \\
- commerce & 3.0 & 1.9 \\
Higher level & & \\
- technical/agricultural & 1.0 & 0.7 \\
- commerce & 8.7 & \\
- arts and community services & 5.2 & \\
Total (incl. other educational categories and & 1.6 & \\
education not known & & \\
\hline
\end{tabular}

Source: CBS/ROA 
Table A2.23a

Percentage share of age groups in the total population

\begin{tabular}{|c|c|c|c|c|c|c|c|c|c|c|c|c|c|c|}
\hline & & $\begin{array}{c}1980 \\
\%\end{array}$ & $\begin{array}{c}1981 \\
\%\end{array}$ & $\begin{array}{c}1982 \\
\%\end{array}$ & $\begin{array}{c}1983 \\
\%\end{array}$ & $\begin{array}{c}1984 \\
\%\end{array}$ & $\begin{array}{c}1985 \\
\%\end{array}$ & $\begin{array}{c}1986 \\
\%\end{array}$ & $\begin{array}{c}1987 \\
\%\end{array}$ & $\begin{array}{c}1988 \\
\%\end{array}$ & $\begin{array}{c}1989 \\
\%\end{array}$ & $\begin{array}{c}1990 \\
\%\end{array}$ & $\begin{array}{c}1991 \\
\%\end{array}$ & $\begin{array}{c}1992 \\
\%\end{array}$ \\
\hline Netherlands & $\begin{array}{l}15-24 \\
25-49 \\
50-65\end{array}$ & $\begin{array}{l}17.3 \\
34.2 \\
14.4\end{array}$ & $\begin{array}{l}17.4 \\
34.5 \\
14.5\end{array}$ & $\begin{array}{l}17.4 \\
35.2 \\
14.5\end{array}$ & $\begin{array}{l}17.3 \\
35.2 \\
14.6\end{array}$ & $\begin{array}{l}17.3 \\
35.1 \\
14.6\end{array}$ & $\begin{array}{l}17.3 \\
36.2 \\
14.8\end{array}$ & $\begin{array}{l}17.2 \\
36.5 \\
14.7\end{array}$ & $\begin{array}{l}16.9 \\
37.4 \\
14.8\end{array}$ & $\begin{array}{l}16.6 \\
37.9 \\
14.7\end{array}$ & $\begin{array}{l}16.2 \\
38.4 \\
14.6\end{array}$ & $\begin{array}{l}15.7 \\
38.7 \\
14.7\end{array}$ & $\begin{array}{l}15.2 \\
39.1 \\
14.5\end{array}$ & $\begin{array}{l}-- \\
- \\
-\end{array}$ \\
\hline France & $\begin{array}{l}15-24 \\
25-49 \\
50-65\end{array}$ & $\begin{array}{l}15.9 \\
33.3 \\
15.3\end{array}$ & $\begin{array}{l}15.8 \\
33.4 \\
15.8\end{array}$ & $\begin{array}{l}15.7 \\
33.5 \\
16.2\end{array}$ & $\begin{array}{l}15.6 \\
33.7 \\
16.6\end{array}$ & $\begin{array}{l}15.6 \\
33.3 \\
16.7\end{array}$ & $\begin{array}{l}15.6 \\
34.1 \\
16.5\end{array}$ & $\begin{array}{l}15.5 \\
34.4 \\
16.4\end{array}$ & $\begin{array}{l}15.1 \\
35.0 \\
16.4\end{array}$ & $\begin{array}{l}15.9 \\
35.9 \\
15.8\end{array}$ & $\begin{array}{l}15.2 \\
35.3 \\
16.0\end{array}$ & $\begin{array}{l}15.0 \\
35.7 \\
15.6\end{array}$ & $\begin{array}{l}14.7 \\
36.1 \\
15.3\end{array}$ & $\begin{array}{l}-- \\
-- \\
-\end{array}$ \\
\hline $\begin{array}{l}\text { Germany } \\
\text { (West) }\end{array}$ & $\begin{array}{l}15-24+ \\
25-49 \\
50-65\end{array}$ & $\begin{array}{l}15.6 \\
34.1 \\
16.2\end{array}$ & $\begin{array}{l}16.1 \\
34.2 \\
16.6\end{array}$ & $\begin{array}{l}16.3 \\
34.4 \\
17.1\end{array}$ & $\begin{array}{l}16.7 \\
35.3 \\
17.3\end{array}$ & $\begin{array}{l}16.7 \\
35.2 \\
18.1\end{array}$ & $\begin{array}{l}16.5 \\
35.2 \\
18.4\end{array}$ & $\begin{array}{l}16.3 \\
35.4 \\
18.4\end{array}$ & $\begin{array}{l}15.7 \\
35.6 \\
18.6\end{array}$ & $\begin{array}{l}15.0 \\
35.6 \\
18.9\end{array}$ & $\begin{array}{l}14.3 \\
36.0 \\
19.1\end{array}$ & $\begin{array}{l}13.8 \\
36.2 \\
19.5\end{array}$ & $\begin{array}{l}15.9 \\
36.2 \\
18.0\end{array}$ & $\begin{array}{l}-- \\
-- \\
-\end{array}$ \\
\hline $\begin{array}{l}\text { United } \\
\text { Kingdom }\end{array}$ & $\begin{array}{l}15-24 \\
25-49 \\
50-65\end{array}$ & $\begin{array}{l}-- \\
-- \\
-\end{array}$ & $\begin{array}{l}15.8 \\
31.8 \\
16.8\end{array}$ & $\begin{array}{l}-- \\
-- \\
--\end{array}$ & $\begin{array}{l}-- \\
--\end{array}$ & $\begin{array}{l}-- \\
- \\
-\end{array}$ & $\begin{array}{l}-- \\
-- \\
-\end{array}$ & $\begin{array}{l}16.3 \\
33.2 \\
16.2\end{array}$ & $\begin{array}{l}-- \\
-- \\
-\end{array}$ & $\begin{array}{l}15.7 \\
33.9 \\
15.9\end{array}$ & $\begin{array}{l}-- \\
-- \\
-\end{array}$ & $\begin{array}{l}14.8 \\
40.4^{*} \\
10.2\end{array}$ & $\begin{array}{l}14.2 \\
40.7 \\
10.1\end{array}$ & $\begin{array}{l}-- \\
- \\
-\end{array}$ \\
\hline Sweden & $\begin{array}{l}15-24 \\
25-49 \\
50-65\end{array}$ & $\begin{array}{l}12.0 \\
33.4 \\
17.3\end{array}$ & $\begin{array}{l}-- \\
-- \\
-\end{array}$ & $\begin{array}{l}12.3 \\
33.7 \\
17.0\end{array}$ & $\begin{array}{l}12.5 \\
34.0 \\
16.8\end{array}$ & $\begin{array}{l}12.6 \\
34.2 \\
16.6\end{array}$ & $\begin{array}{l}12.6 \\
34.4 \\
16.3\end{array}$ & $\begin{array}{l}12.6 \\
34.3 \\
16.2\end{array}$ & $\begin{array}{l}12.7 \\
34.8 \\
15.7\end{array}$ & $\begin{array}{l}- \\
-- \\
-\end{array}$ & $\begin{array}{l}12.5 \\
35.0 \\
15.3\end{array}$ & $\begin{array}{l}12.4 \\
35.2 \\
15.2\end{array}$ & $\begin{array}{l}12.2 \\
35.6 \\
15.2\end{array}$ & $\begin{array}{l}11.9 \\
35.9 \\
15.4\end{array}$ \\
\hline Austria & $\begin{array}{l}15-24 \\
25-49 \\
50-65\end{array}$ & $\begin{array}{l}14.4 \\
34.0 \\
15.6\end{array}$ & $\begin{array}{l}16.7 \\
32.3 \\
15.8\end{array}$ & $\begin{array}{l}16.7 \\
32.6 \\
16.2\end{array}$ & $\begin{array}{l}16.6 \\
33.3 \\
16.5\end{array}$ & $\begin{array}{l}17.0 \\
33.5 \\
16.7\end{array}$ & $\begin{array}{l}16.9 \\
34.0 \\
16.6\end{array}$ & $\begin{array}{l}16.7 \\
34.6 \\
16.3\end{array}$ & $\begin{array}{l}16.3 \\
35.3 \\
16.0\end{array}$ & $\begin{array}{l}15.9 \\
35.9 \\
15.8\end{array}$ & $\begin{array}{l}15.4 \\
36.2 \\
15.8\end{array}$ & $\begin{array}{l}15.1 \\
36.3 \\
16.1\end{array}$ & $\begin{array}{l}14.8 \\
36.3 \\
16.3\end{array}$ & $\begin{array}{l}-- \\
- \\
-\end{array}$ \\
\hline U.S.A. & $\begin{array}{l}15-24 \\
25-49 \\
50-65\end{array}$ & $\begin{array}{l}16.9 \\
32.4 \\
14.7\end{array}$ & $\begin{array}{l}17.3 \\
33.2 \\
14.6\end{array}$ & $\begin{array}{l}19.5 \\
33.9 \\
14.4\end{array}$ & $\begin{array}{l}-- \\
-- \\
--\end{array}$ & $\begin{array}{l}17.0 \\
35.1 \\
14.1\end{array}$ & $\begin{array}{l}16.6 \\
35.8 \\
13.9\end{array}$ & $\begin{array}{l}16.2 \\
36.4 \\
13.7\end{array}$ & $\begin{array}{l}15.7 \\
37.0 \\
13.5\end{array}$ & $\begin{array}{l}15.2 \\
37.4 \\
13.4\end{array}$ & $\begin{array}{l}13.5 \\
38.1 \\
13.4\end{array}$ & $\begin{array}{l}14.7 \\
37.8 \\
13.3\end{array}$ & $\begin{array}{l}14.4 \\
38.2 \\
12.9\end{array}$ & $\begin{array}{l}14.2 \\
38.3 \\
12.9\end{array}$ \\
\hline Japan & $\begin{array}{l}15-24 \\
25-49 \\
50-65\end{array}$ & $\begin{array}{l}13.8 \\
38.9 \\
14.7\end{array}$ & $\begin{array}{l}13.6 \\
38.6 \\
15.1\end{array}$ & $\begin{array}{l}13.7 \\
38.2 \\
15.5\end{array}$ & $\begin{array}{l}13.8 \\
37.8 \\
16.0\end{array}$ & $\begin{array}{l}14.0 \\
37.6 \\
16.4\end{array}$ & $\begin{array}{l}14.2 \\
37.2 \\
16.8\end{array}$ & $\begin{array}{l}14.4 \\
36.9 \\
17.2\end{array}$ & $\begin{array}{l}14.7 \\
36.5 \\
17.5\end{array}$ & $\begin{array}{l}15.0 \\
36.3 \\
17.8\end{array}$ & $\begin{array}{l}15.2 \\
36.2 \\
18.0\end{array}$ & $\begin{array}{l}15.3 \\
36.2 \\
18.2\end{array}$ & $\begin{array}{l}15.5 \\
35.8 \\
18.5\end{array}$ & $\begin{array}{l}15.5 \\
35.4 \\
18.8\end{array}$ \\
\hline \multicolumn{15}{|c|}{$\begin{array}{l}\text { * not available } \\
\text { In } 1990 \text { the age groups } 45-49 \text { and } 50-54 \text { in the United Kingdom have been joined to one age group. This } 45-54 \text { age } \\
\text { group is included under the heading } 25-49\end{array}$} \\
\hline
\end{tabular}


Table $A 2.23 b$

Percentage share of age groups in the labour force

\begin{tabular}{|c|c|c|c|c|c|c|c|c|c|c|c|c|c|c|}
\hline & & $\begin{array}{c}1980 \\
\%\end{array}$ & $\begin{array}{c}1981 \\
\%\end{array}$ & $\begin{array}{c}1982 \\
\%\end{array}$ & $\begin{array}{c}1983 \\
\%\end{array}$ & $\begin{array}{c}1984 \\
\%\end{array}$ & $\begin{array}{c}1985 \\
\%\end{array}$ & $\begin{array}{c}1986 \\
\%\end{array}$ & $\begin{array}{c}1987 \\
\%\end{array}$ & $\begin{array}{c}1988 \\
\%\end{array}$ & $\begin{array}{c}1989 \\
\%\end{array}$ & $\begin{array}{c}1990 \\
\%\end{array}$ & $\begin{array}{c}1991 \\
\%\end{array}$ & $\begin{array}{c}1992 \\
\%\end{array}$ \\
\hline Netherlands & $\begin{array}{l}15-24 \\
25-49 \\
50-65\end{array}$ & $\begin{array}{l}21.6 \\
59.7 \\
17.2\end{array}$ & $\begin{array}{l}22.0 \\
61.0 \\
16.3\end{array}$ & $\begin{array}{l}21.5 \\
62.1 \\
15.7\end{array}$ & $\begin{array}{l}21.6 \\
62.2 \\
15.6\end{array}$ & $\begin{array}{l}21.6 \\
62.2 \\
15.6\end{array}$ & $\begin{array}{l}20.5 \\
63.9 \\
15.0\end{array}$ & $\begin{array}{l}20.2 \\
64.6 \\
14.7\end{array}$ & $\begin{array}{l}22.6 \\
63.7 \\
12.0\end{array}$ & $\begin{array}{l}22.0 \\
64.5 \\
13.5\end{array}$ & $\begin{array}{l}21.3 \\
65.3 \\
13.4\end{array}$ & $\begin{array}{l}20.9 \\
65.8 \\
13.3\end{array}$ & $\begin{array}{l}20.3 \\
66.8 \\
12.9\end{array}$ & $\begin{array}{l}-- \\
--\end{array}$ \\
\hline France & $\begin{array}{l}15-24 \\
25-49 \\
50-65\end{array}$ & $\begin{array}{l}17.2 \\
60.4 \\
21.0\end{array}$ & $\begin{array}{l}16.8 \\
61.0 \\
21.0\end{array}$ & $\begin{array}{l}16.7 \\
61.7 \\
20.7\end{array}$ & $\begin{array}{l}16.3 \\
62.7 \\
20.1\end{array}$ & $\begin{array}{l}16.0 \\
63.4 \\
19.6\end{array}$ & $\begin{array}{l}15.8 \\
64.1 \\
19.2\end{array}$ & $\begin{array}{l}15.3 \\
65.0 \\
18.9\end{array}$ & $\begin{array}{l}13.6 \\
66.6 \\
18.9\end{array}$ & $\begin{array}{l}-- \\
-- \\
--\end{array}$ & $\begin{array}{l}13.3 \\
67.3 \\
18.5\end{array}$ & $\begin{array}{l}12.4 \\
68.5 \\
18.3\end{array}$ & $\begin{array}{l}11.6 \\
69.9 \\
17.7\end{array}$ & $\begin{array}{l}-- \\
--\end{array}$ \\
\hline $\begin{array}{l}\text { Germany } \\
\text { (West) }\end{array}$ & $\begin{array}{l}15-24 \\
25-49 \\
50-65\end{array}$ & $\begin{array}{l}20.6 \\
58.1 \\
19.6\end{array}$ & $\begin{array}{l}20.8 \\
57.9 \\
19.8\end{array}$ & $\begin{array}{l}20.7 \\
58.0 \\
20.0\end{array}$ & $\begin{array}{l}20.8 \\
58.4 \\
19.6\end{array}$ & $\begin{array}{l}21.1 \\
58.1 \\
19.6\end{array}$ & $\begin{array}{l}21.2 \\
58.2 \\
19.5\end{array}$ & $\begin{array}{l}20.9 \\
58.2 \\
19.9\end{array}$ & $\begin{array}{l}20.2 \\
58.4 \\
20.3\end{array}$ & $\begin{array}{l}19.5 \\
58.6 \\
21.0\end{array}$ & $\begin{array}{l}18.3 \\
59.6 \\
21.3\end{array}$ & $\begin{array}{l}17.3 \\
59.6 \\
22.1\end{array}$ & $\begin{array}{l}15.9 \\
62.7 \\
21.2\end{array}$ & $\begin{array}{l}-- \\
-- \\
-\end{array}$ \\
\hline $\begin{array}{l}\text { United } \\
\text { Kingdom }\end{array}$ & $\begin{array}{l}15-24 \\
25-49 \\
50-65\end{array}$ & $\begin{array}{l}-- \\
-- \\
-\end{array}$ & $\begin{array}{l}21.0 \\
53.3 \\
23.6\end{array}$ & $\begin{array}{l}-- \\
-- \\
--\end{array}$ & $\begin{array}{l}-- \\
--\end{array}$ & $\begin{array}{l}-- \\
--\end{array}$ & -- & $\begin{array}{l}22.9 \\
55.3 \\
13.0\end{array}$ & $\begin{array}{l}- \\
- \\
-\end{array}$ & $\begin{array}{l}22.3 \\
56.4 \\
19.8\end{array}$ & $\begin{array}{l}- \\
-- \\
-\end{array}$ & $\begin{array}{l}20.9 \\
66.8 \\
10.7\end{array}$ & $\begin{array}{l}19.9 \\
67.8 \\
10.7\end{array}$ & $\begin{array}{l}-- \\
-- \\
-\end{array}$ \\
\hline Sweden & $\begin{array}{l}15-24 \\
25-49 \\
50-65\end{array}$ & $\begin{array}{l}14.5 \\
58.5 \\
25.3\end{array}$ & $\begin{array}{l}-- \\
-- \\
--\end{array}$ & $\begin{array}{l}15.7 \\
58.5 \\
24.2\end{array}$ & $\begin{array}{l}15.5 \\
59.1 \\
23.9\end{array}$ & $\begin{array}{l}15.5 \\
59.7 \\
23.5\end{array}$ & $\begin{array}{l}15.7 \\
60.1 \\
22.9\end{array}$ & $\begin{array}{l}16.2 \\
60.4 \\
23.4\end{array}$ & $\begin{array}{l}16.0 \\
61.3 \\
22.7\end{array}$ & $\begin{array}{l}-- \\
-- \\
--\end{array}$ & $\begin{array}{l}16.3 \\
61.5 \\
22.1\end{array}$ & $\begin{array}{l}15.8 \\
61.9 \\
22.3\end{array}$ & $\begin{array}{l}14.9 \\
62.5 \\
22.6\end{array}$ & $\begin{array}{l}13.5 \\
63.5 \\
23.1\end{array}$ \\
\hline Austria & $\begin{array}{l}15-24 \\
25-49 \\
50-65\end{array}$ & $\begin{array}{l}19.7 \\
59.8 \\
19.8\end{array}$ & $\begin{array}{l}25.4 \\
56.5 \\
17.3\end{array}$ & $\begin{array}{l}23.3 \\
58.2 \\
17.7\end{array}$ & $\begin{array}{l}23.5 \\
58.9 \\
17.0\end{array}$ & $\begin{array}{l}24.6 \\
58.5 \\
16.4\end{array}$ & $\begin{array}{l}24.1 \\
59.8 \\
15.6\end{array}$ & $\begin{array}{l}23.9 \\
60.7 \\
14.9\end{array}$ & $\begin{array}{l}23.7 \\
61.4 \\
14.4\end{array}$ & $\begin{array}{l}22.7 \\
62.7 \\
14.2\end{array}$ & $\begin{array}{l}21.7 \\
63.5 \\
14.4\end{array}$ & $\begin{array}{l}20.8 \\
63.6 \\
15.1\end{array}$ & $\begin{array}{l}20.4 \\
63.7 \\
15.6\end{array}$ & $\begin{array}{l}-- \\
--\end{array}$ \\
\hline U.S.A. & $\begin{array}{l}15-24 \\
25-49 \\
50-65\end{array}$ & $\begin{array}{l}23.0 \\
54.6 \\
19.3\end{array}$ & $\begin{array}{l}23.7 \\
55.2 \\
18.4\end{array}$ & $\begin{array}{l}22.9 \\
56.3 \\
18.1\end{array}$ & $\begin{array}{l}-- \\
--\end{array}$ & $\begin{array}{l}21.1 \\
58.9 \\
17.6\end{array}$ & $\begin{array}{l}20.2 \\
58.8 \\
17.1\end{array}$ & $\begin{array}{l}19.8 \\
60.6 \\
17.0\end{array}$ & $\begin{array}{l}19.2 \\
61.5 \\
16.8\end{array}$ & $\begin{array}{l}18.3 \\
61.3 \\
16.4\end{array}$ & $\begin{array}{l}17.6 \\
61.9 \\
16.4\end{array}$ & $\begin{array}{l}-- \\
-- \\
--\end{array}$ & $\begin{array}{l}16.3 \\
63.3 \\
16.5\end{array}$ & $\begin{array}{l}15.9 \\
63.4 \\
16.7\end{array}$ \\
\hline Japan & $\begin{array}{l}15-24 \\
25-49 \\
50-65\end{array}$ & $\begin{array}{l}12.4 \\
61.6 \\
21.0\end{array}$ & $\begin{array}{l}12.3 \\
61.3 \\
21.4\end{array}$ & $\begin{array}{l}12.2 \\
60.9 \\
22.0\end{array}$ & $\begin{array}{l}12.4 \\
60.1 \\
22.5\end{array}$ & $\begin{array}{l}12.4 \\
59.8 \\
22.9\end{array}$ & $\begin{array}{l}12.3 \\
59.3 \\
23.4\end{array}$ & $\begin{array}{l}12.5 \\
58.6 \\
23.8\end{array}$ & $\begin{array}{l}12.6 \\
58.1 \\
24.2\end{array}$ & $\begin{array}{l}12.7 \\
57.5 \\
24.6\end{array}$ & $\begin{array}{l}12.9 \\
57.1 \\
24.6\end{array}$ & $\begin{array}{l}13.1 \\
56.5 \\
24.8\end{array}$ & $\begin{array}{l}13.4 \\
55.4 \\
25.2\end{array}$ & $\begin{array}{l}13.6 \\
54.5 \\
25.6\end{array}$ \\
\hline
\end{tabular}

-- not available

* In 1990 the age groups 45-49 and 50-54 in the United Kingdom have been joined to one age group. This $45-54$ age group is included under the heading $25-49$

Source: ILO/OECD/ROA

Table A2.24a

Population aged 15-64, excluding those in full-time education, by educational sectors

\begin{tabular}{|c|c|c|c|c|c|c|c|}
\hline & 1990 & 1991 & 1992 & 1993 & 1994 & 1995 & 1996 \\
\hline $\begin{array}{l}\text { Primary education } \\
\text { Low. sec. general education } \\
\text { Low. sec. vocational education } \\
\text { Intermediate general education } \\
\text { Intermediate vocational education } \\
\text { Higher vocational education } \\
\text { University education }\end{array}$ & $\begin{array}{r}1,557,943 \\
812,681 \\
1,800,723 \\
401,147 \\
3,017,695 \\
1,146,521 \\
450,263\end{array}$ & $\begin{array}{r}1,520,788 \\
825,767 \\
1,820,993 \\
409,415 \\
3,042,899 \\
1,169,723 \\
466,227\end{array}$ & $\begin{array}{r}1,482,482 \\
838,724 \\
1836,168 \\
417,125 \\
3,066,147 \\
1,194,885 \\
482,601\end{array}$ & $\begin{array}{r}1,445,403 \\
852,791 \\
1,851,943 \\
424,424 \\
3,089,797 \\
1,221,329 \\
499,994\end{array}$ & $\begin{array}{r}1,411,014 \\
867,767 \\
1,865,631 \\
431,988 \\
3,112,694 \\
1,248,300 \\
518,278\end{array}$ & $\begin{array}{r}1,376,759 \\
881,669 \\
1,873,701 \\
439,430 \\
3,131,039 \\
1,273,173 \\
537,011\end{array}$ & $\begin{array}{r}1,345,590 \\
894,896 \\
1,880,336 \\
446,431 \\
3,147,364 \\
1,297,701 \\
555,915\end{array}$ \\
\hline $\begin{array}{l}\text { Total } \\
9,568,233\end{array}$ & $9,186,973$ & $9,255,812$ & $9,318,132$ & $9,385,681$ & $9,455,672$ & $9,512,782$ & \\
\hline
\end{tabular}

Source: Ministerie van Onderwijs en Wetenschappen, 1993/ROA 


\begin{tabular}{|c|c|c|c|c|c|c|c|}
\hline & 1990 & 1991 & 1992 & 1993 & 1994 & 1995 & 1996 \\
\hline Primary education & $1,315,409$ & $1,288,298$ & $1,262,193$ & $1,237,944$ & $1,215,291$ & $1,194,888$ & $1,174,992$ \\
\hline Low. sec. general education & 907,351 & 919,496 & 930,740 & 940,734 & 949,811 & 958,398 & 966,372 \\
\hline Low. sec. vocational education & $1,884,704$ & $1,888,230$ & $1,889,560$ & $1,889,015$ & $1,887,499$ & $1,885,840$ & $1,883,378$ \\
\hline Intermediate general education & 452,848 & 458,846 & 464,558 & 470,124 & 475,650 & 481,337 & 487,020 \\
\hline Intermediate vocational education & $3,160,647$ & $3,173,258$ & $3,184,349$ & $3,195,235$ & $3,205,193$ & $3,214,492$ & $3,220,075$ \\
\hline Higher vocational education & $1,320,549$ & $1,342,385$ & $1,362,648$ & $1,381,990$ & $1,400,440$ & $1,418,463$ & $1,435,063$ \\
\hline University education & 574,596 & 592,582 & 609,845 & 626,667 & 643,178 & 659,447 & 675,077 \\
\hline Total & $9,616,104$ & $9,663,095$ & $9,703,893$ & $9,741,709$ & $9,777,062$ & $9,812,865$ & $9,841,977$ \\
\hline
\end{tabular}

Source: Referentieraming 1993/ROA

Table A2.24a

continued

\begin{tabular}{|c|c|c|c|c|c|c|c|}
\hline & 2004 & 2005 & 2006 & 2007 & 2008 & 2009 & 2010 \\
\hline $\begin{array}{l}\text { Primary education } \\
\text { Low. sec. general education } \\
\text { Low. sec. vocational education } \\
\text { Intermediate general education } \\
\text { Intermediate vocational education } \\
\text { Higher vocational education } \\
\text { University education } \\
\text { Total }\end{array}$ & $\begin{array}{r}1,156,845 \\
974,291 \\
1,881,256 \\
492,689 \\
3,223,809 \\
1,450,719 \\
690,271 \\
9,869,880\end{array}$ & $\begin{array}{r}1,140,514 \\
981,934 \\
1,879,208 \\
498,161 \\
3,224,480 \\
1,464,885 \\
704,772 \\
9,893,954\end{array}$ & $\begin{array}{r}1,127,033 \\
990,193 \\
1,878,860 \\
503,571 \\
3,225,797 \\
1,478,931 \\
719,175 \\
9,923,560\end{array}$ & $\begin{array}{r}1,114,226 \\
998,102 \\
1,878,198 \\
508,913 \\
3,224,465 \\
1,491,665 \\
732,845 \\
9,948,414\end{array}$ & $\begin{array}{r}1,100,108 \\
1,005,245 \\
1,875,836 \\
514,246 \\
3,219,008 \\
1,502,499 \\
745,608 \\
9,962,550\end{array}$ & $\begin{array}{r}1,085,451 \\
1,011,948 \\
1,872,649 \\
519,313 \\
3,210,882 \\
1,512,142 \\
757,893 \\
9,970,278\end{array}$ & $\begin{array}{r}1,072,447 \\
1,019,199 \\
1,872,104 \\
524,562 \\
3,205,992 \\
1,523,410 \\
770,721 \\
9,988,435\end{array}$ \\
\hline
\end{tabular}

Source: Referentieraming 1993/ROA

Table A2.24b

School-leavers by educational sectors

\begin{tabular}{|c|c|c|c|c|c|c|c|}
\hline & 1990 & 1991 & 1992 & 1993 & 1994 & 1995 & 1996 \\
\hline $\begin{array}{l}\text { Primary education } \\
\text { Low. sec. general education } \\
\text { Low. sec. vocational education } \\
\text { Intermediate general education } \\
\text { Intermediate vocational education } \\
\text { Higher vocational education } \\
\text { University education }\end{array}$ & $\begin{array}{r}20,759 \\
27,885 \\
38,968 \\
7,833 \\
38,941 \\
25,375 \\
19,647\end{array}$ & $\begin{array}{r}19,740 \\
27,093 \\
36,485 \\
8,727 \\
35,592 \\
27,624 \\
20,403\end{array}$ & $\begin{array}{r}18,490 \\
27,617 \\
35,794 \\
8,383 \\
35,213 \\
29,355 \\
21,451\end{array}$ & $\begin{array}{r}18,807 \\
28,348 \\
3,5151 \\
8,227 \\
34,562 \\
30,829 \\
22,493\end{array}$ & $\begin{array}{r}18,808 \\
27,553 \\
34,450 \\
7,894 \\
32,880 \\
31,063 \\
23,323\end{array}$ & $\begin{array}{r}19,591 \\
27,027 \\
34,217 \\
7,583 \\
31,304 \\
31,518 \\
23,696\end{array}$ & $\begin{array}{r}20,096 \\
26,739 \\
34,063 \\
7,452 \\
30,118 \\
31,139 \\
23,908\end{array}$ \\
\hline Total & 179,408 & 175,664 & 176,303 & 178,417 & 175,971 & 174,936 & 173,512 \\
\hline
\end{tabular}

Source: Referentieraming 1993/ROA

Table A2.24b

continued

\begin{tabular}{|c|c|c|c|c|c|c|c|}
\hline & 1997 & 1998 & 1999 & 2000 & 2001 & 2002 & 2003 \\
\hline $\begin{array}{l}\text { Primary education } \\
\text { Low. sec. general education } \\
\text { Low. sec. vocational education } \\
\text { Intermediate general education } \\
\text { Intermediate vocational education } \\
\text { Higher vocational education } \\
\text { University education }\end{array}$ & $\begin{array}{r}20,270 \\
26,559 \\
33,535 \\
7,406 \\
29,214 \\
30,439 \\
23,603\end{array}$ & $\begin{array}{r}20,270 \\
26,236 \\
32,782 \\
7,608 \\
28,945 \\
29,921 \\
23,446\end{array}$ & $\begin{array}{r}20,371 \\
25,648 \\
32,458 \\
7,705 \\
28,799 \\
29,668 \\
23,505\end{array}$ & $\begin{array}{r}20,669 \\
25,002 \\
32,648 \\
7,937 \\
28,520 \\
29,670 \\
23,711\end{array}$ & $\begin{array}{r}21,124 \\
24,672 \\
33,023 \\
8,289 \\
28,059 \\
29,951 \\
23,899\end{array}$ & $\begin{array}{r}21,626 \\
24,714 \\
33,450 \\
8,619 \\
27,645 \\
30,264 \\
24,155\end{array}$ & $\begin{array}{r}22,044 \\
24,961 \\
33,768 \\
8,908 \\
27,472 \\
30,447 \\
24,466\end{array}$ \\
\hline Total & 171,026 & 169,208 & 168,154 & 168,157 & 169,017 & 170,473 & 172,066 \\
\hline
\end{tabular}

Source: Referentieraming 1993/ROA 
Table A2.24b

continued

\begin{tabular}{|c|c|c|c|c|c|c|c|}
\hline & 2004 & 2005 & 2006 & 2007 & 2008 & 2009 & 2010 \\
\hline $\begin{array}{l}\text { Primary education } \\
\text { Low. sec. general education } \\
\text { Low. sec. vocational education } \\
\text { Intermediate general education } \\
\text { Intermediate vocational education } \\
\text { Higher vocational education } \\
\text { University education }\end{array}$ & $\begin{array}{r}22,272 \\
25,247 \\
33,970 \\
9,086 \\
27,601 \\
30,505 \\
24,777\end{array}$ & $\begin{array}{r}22,643 \\
25,541 \\
34,384 \\
9,177 \\
27,860 \\
30,584 \\
25,014\end{array}$ & $\begin{array}{r}23,060 \\
25,861 \\
35,013 \\
9,368 \\
28,141 \\
30,803 \\
25,279\end{array}$ & $\begin{array}{r}23,327 \\
26,260 \\
35,376 \\
9,742 \\
28,447 \\
31,183 \\
25,658\end{array}$ & $\begin{array}{r}23,509 \\
26,635 \\
35,605 \\
9,890 \\
28,867 \\
31,622 \\
26,180\end{array}$ & $\begin{array}{l}23,749 \\
26,889 \\
35,974 \\
10,015 \\
29,329 \\
32,047 \\
26,771\end{array}$ & $\begin{array}{l}24,446 \\
27,149 \\
36,402 \\
10,318 \\
29,750 \\
32,504 \\
27,621\end{array}$ \\
\hline Total & 173,458 & 175,203 & 177,525 & 179,993 & 182,308 & 184,774 & 187,890 \\
\hline
\end{tabular}

Source: Referentieraming 1993/ROA

Table A3.1

Real public expenditure on education as a percentage of GDP

\begin{tabular}{|c|c|c|c|c|c|c|c|c|c|}
\hline Country & $\begin{array}{c}1974 \\
\%\end{array}$ & $\begin{array}{c}1975 \\
\%\end{array}$ & $\begin{array}{c}1976 \\
\%\end{array}$ & $\begin{array}{c}1977 \\
\%\end{array}$ & $\begin{array}{c}1978 \\
\%\end{array}$ & $\begin{array}{c}1979 \\
\%\end{array}$ & $\begin{array}{c}1980 \\
\%\end{array}$ & $\begin{array}{c}1981 \\
\%\end{array}$ & $\begin{array}{c}1982 \\
\%\end{array}$ \\
\hline $\begin{array}{l}\text { Belgium } \\
\text { France } \\
\text { Germany } \\
\text { Ireland } \\
\text { Japan } \\
\text { Netherlands } \\
\text { Sweden } \\
\text { United Kingdom } \\
\text { United States }\end{array}$ & $\begin{array}{l}6.2 \\
5.5 \\
4.9 \\
7.3 \\
5.4 \\
7.1 \\
7.3 \\
6.9 \\
5.5\end{array}$ & $\begin{array}{l}5.9 \\
5.6 \\
5.2 \\
6.5 \\
5.3 \\
7.4 \\
7.1 \\
6.8 \\
5.7\end{array}$ & $\begin{array}{l}5.8 \\
5.5 \\
4.9 \\
6.6 \\
5.3 \\
7.2 \\
7.2 \\
6.4 \\
5.6\end{array}$ & $\begin{array}{l}6.1 \\
5.4 \\
4.7 \\
6.5 \\
5.4 \\
7.1 \\
7.7 \\
6.0 \\
5.3\end{array}$ & $\begin{array}{l}6.0 \\
5.3 \\
4.7 \\
6.6 \\
5.7 \\
7.1 \\
8.0 \\
5.8 \\
5.0\end{array}$ & $\begin{array}{l}6.0 \\
5.2 \\
4.6 \\
6.6 \\
5.6 \\
7.0 \\
8.6 \\
5.7 \\
4.9\end{array}$ & $\begin{array}{l}5.7 \\
5.1 \\
4.6 \\
6.6 \\
5.9 \\
7.1 \\
8.5 \\
5.7 \\
4.9\end{array}$ & $\begin{array}{l}5.7 \\
5.5 \\
4.6 \\
6.4 \\
5.5 \\
7.2 \\
8.0 \\
5.6 \\
4.8\end{array}$ & $\begin{array}{l}5.7 \\
5.6 \\
4.6 \\
6.6 \\
5.3 \\
7.2 \\
7.8 \\
5.5 \\
4.9\end{array}$ \\
\hline
\end{tabular}

Source: OECD, Education at a Glance 1992/1993; Public Educational Expenditure, Costs and Financing (1992)

Table A3. 1

continued

\begin{tabular}{|c|c|c|c|c|c|c|c|c|c|}
\hline Country & $\begin{array}{c}1983 \\
\%\end{array}$ & $\begin{array}{c}1984 \\
\%\end{array}$ & $\begin{array}{c}1985 \\
\%\end{array}$ & $\begin{array}{c}1986 \\
\%\end{array}$ & $\begin{array}{c}1987 \\
\%\end{array}$ & $\begin{array}{c}1988 \\
\%\end{array}$ & $\begin{array}{c}1989 \\
\%\end{array}$ & $\begin{array}{c}1990 \\
\%\end{array}$ & $\begin{array}{c}1991 \\
\%\end{array}$ \\
\hline $\begin{array}{l}\text { Belgium } \\
\text { France } \\
\text { Germany } \\
\text { Ireland } \\
\text { Japan } \\
\text { Netherlands } \\
\text { Sweden } \\
\text { United Kingdom } \\
\text { United States }\end{array}$ & $\begin{array}{l}5.6 \\
5.7 \\
4.4 \\
6.1 \\
5.1 \\
7.0 \\
7.4 \\
5.2 \\
4.8\end{array}$ & $\begin{array}{l}5.5 \\
5.7 \\
4.1 \\
6.3 \\
4.9 \\
6.6 \\
7.2 \\
5.2 \\
4.6\end{array}$ & $\begin{array}{l}5.6 \\
5.7 \\
4.1 \\
6.0 \\
4.7 \\
6.6 \\
7.0 \\
4.9 \\
4.6\end{array}$ & $\begin{array}{l}5.5 \\
5.7 \\
4.1 \\
6.0 \\
4.7 \\
6.7 \\
7.0 \\
4.9 \\
4.8\end{array}$ & $\begin{array}{l}5.3 \\
5.6 \\
4.0 \\
6.3 \\
4.5 \\
6.9 \\
6.9 \\
4.8 \\
4.8\end{array}$ & $\begin{array}{l}5.0 \\
5.5 \\
4.3 \\
6.2 \\
4.4 \\
6.3 \\
6.5 \\
4.7 \\
5.0\end{array}$ & $\begin{array}{l}5.7 \\
-- \\
-- \\
5.3 \\
-- \\
-- \\
5.5 \\
4.9 \\
5.1\end{array}$ & $\begin{array}{l}5.2 \\
-- \\
-- \\
5.2 \\
-- \\
-- \\
5.7 \\
5.1 \\
5.6\end{array}$ & $\begin{array}{l}5.4 \\
5.4 \\
4.0 \\
5.5 \\
3.7 \\
5.6 \\
6.5 \\
5.3 \\
5.5\end{array}$ \\
\hline
\end{tabular}

Source: OECD, Education at a Glance 1992/1993; Public Educational Expenditure, Costs and Financing (1992) 
Table A3.3

Public expenditure per student in equivalent US dollars using purchasing power parities

\begin{tabular}{|c|c|c|c|c|c|c|c|}
\hline Country & $\begin{array}{c}1985 \\
\$\end{array}$ & $\begin{array}{c}1986 \\
\$\end{array}$ & $\begin{array}{c}1987 \\
\$\end{array}$ & $\begin{array}{c}1988 \\
\$\end{array}$ & $\begin{array}{c}1989 \\
\$\end{array}$ & $\begin{array}{c}1990 \\
\$\end{array}$ & $\begin{array}{c}1991 \\
\$\end{array}$ \\
\hline $\begin{array}{l}\text { Austria } \\
\text { Belgium } \\
\text { Denmark } \\
\text { Ireland } \\
\text { Japan* } \\
\text { Netherlands* } \\
\text { Norway } \\
\text { Sweden } \\
\text { United Kingdom } \\
\text { United States }\end{array}$ & $\begin{array}{r}3,386 \\
3,353 \\
3,786 \\
1,506 \\
-- \\
3,079 \\
3,447 \\
-- \\
3,401 \\
4,181\end{array}$ & $\begin{array}{l}3,591 \\
3,408 \\
3,867 \\
1,573 \\
2,776 \\
3,333 \\
3,970 \\
4,482 \\
3,449 \\
4,469\end{array}$ & $\begin{array}{l}3,708 \\
3,422 \\
4,210 \\
1,714 \\
2,922 \\
3,686 \\
4,405 \\
4,722 \\
3,795 \\
4,821\end{array}$ & $\begin{array}{l}3,849 \\
3,585 \\
4,639 \\
1,707 \\
3,159 \\
3,784 \\
4,762 \\
4,956 \\
4,083 \\
5,124\end{array}$ & $\begin{array}{l}4,078 \\
3,679 \\
4,923 \\
1,773 \\
3,430 \\
3,938 \\
5,079 \\
5,023 \\
4,018 \\
5,362\end{array}$ & $\begin{array}{l}4,354 \\
3,670 \\
5,189 \\
1,972 \\
3,688 \\
4,217 \\
5,074 \\
5,543 \\
4,791 \\
6,146\end{array}$ & $\begin{array}{l}4,730 \\
4,003 \\
5,492 \\
2,199 \\
4,203 \\
4,268 \\
5,612 \\
6,160 \\
4,892 \\
6,532\end{array}$ \\
\hline $\begin{array}{ll}- & \text { not available } \\
* & \text { public + priva }\end{array}$ & . & & & & & & \\
\hline
\end{tabular}

Source: OECD, Education at a glance

Table A3.5

Public expenditure per student in higher education in equivalent US dollars using purchasing power parities

\begin{tabular}{|c|c|c|c|c|c|c|c|}
\hline Country & $\begin{array}{c}1985 \\
\$\end{array}$ & $\begin{array}{c}1986 \\
\$\end{array}$ & $\begin{array}{c}1987 \\
\$\end{array}$ & $\begin{array}{c}1988 \\
\$\end{array}$ & $\begin{array}{c}1989 \\
\$\end{array}$ & $\begin{array}{c}1990 \\
\$\end{array}$ & $\begin{array}{c}1991 \\
\$\end{array}$ \\
\hline $\begin{array}{l}\text { Austria } \\
\text { Belgium } \\
\text { Denmark } \\
\text { Ireland } \\
\text { Japan* } \\
\text { Netherlands* } \\
\text { Norway } \\
\text { Sweden } \\
\text { United States }\end{array}$ & $\begin{array}{r}5,030 \\
5,445 \\
6,574 \\
3,968 \\
-- \\
7,251 \\
6,027 \\
-- \\
7,841\end{array}$ & $\begin{array}{l}5,763 \\
5,651 \\
6,857 \\
4,121 \\
4,711 \\
7,706 \\
7,230 \\
6,065 \\
8,582\end{array}$ & $\begin{array}{l}5,637 \\
5,596 \\
6,756 \\
4,781 \\
4,901 \\
9,017 \\
7,625 \\
6,438 \\
9,076\end{array}$ & $\begin{array}{c}5,764 \\
4,987 \\
7,428 \\
4,453 \\
5,184 \\
8,545 \\
8,077 \\
7,113 \\
9,531\end{array}$ & $\begin{array}{l}5,937 \\
5,711 \\
7,804 \\
4,411 \\
5,445 \\
8,914 \\
8,952 \\
6,609 \\
8,631\end{array}$ & $\begin{array}{r}5,933 \\
5,755 \\
7,762 \\
5,149 \\
5,618 \\
9,659 \\
8,038 \\
8,076 \\
11,191\end{array}$ & $\begin{array}{r}6,442 \\
6,235 \\
7,689 \\
5,438 \\
5,994 \\
9,353 \\
8,403 \\
8,564 \\
11,810\end{array}$ \\
\hline $\begin{array}{ll}- & \text { not availa } \\
* & \text { public }+p\end{array}$ & ex & & & & & & \\
\hline
\end{tabular}

Source: OECD, Education at a glance

Table A3. 7a

University degrees awarded (ISCED 6/7)

\begin{tabular}{|c|c|c|c|c|c|c|c|}
\hline & 1985 & 1986 & 1987 & 1988 & 1989 & 1990 & 1991 \\
\hline $\begin{array}{l}\text { Austria } \\
\text { Denmark } \\
\text { Germany } \\
\text { Japan } \\
\text { Netherlands } \\
\text { Sweden } \\
\text { Switzerland } \\
\text { United States }\end{array}$ & $\begin{array}{r}9,382 \\
12,881 \\
146,920 \\
399,207 \\
17,857 \\
18,392 \\
9,136 \\
1,373,734\end{array}$ & $\begin{array}{r}9,198 \\
13,267 \\
150,112 \\
404,184 \\
19,462 \\
17,022 \\
9,403 \\
1,383,953\end{array}$ & $\begin{array}{r}9,906 \\
13,367 \\
154,840 \\
412,190 \\
22,667 \\
18,024 \\
9,989 \\
1,387,766\end{array}$ & $\begin{array}{r}10,579 \\
13,506 \\
159,132 \\
414,456 \\
30,377 \\
18,253 \\
10,438 \\
1,399,751\end{array}$ & $\begin{array}{r}9,657 \\
16,079 \\
162,988 \\
410,643 \\
27,590 \\
18,046 \\
10,678 \\
1,435,952\end{array}$ & $\begin{array}{r}11,282 \\
17,479 \\
166,101 \\
435,080 \\
22,102 \\
17,078 \\
11,156 \\
1,482,619\end{array}$ & $\begin{array}{r}11,665 \\
18,180 \\
171,941 \\
464,774 \\
23,190 \\
17,579 \\
11,466 \\
1544,000\end{array}$ \\
\hline
\end{tabular}

Source: OECD, Education at a glance 
Table A3. $7 b$

Scientific degrees awarded (ISCED 6/7)

\begin{tabular}{lrrrrrrr}
\hline & 1985 & 1986 & 1987 & 1988 & 1989 & 1990 & 1991 \\
\hline Austria & 1,741 & 1,599 & 1,794 & 2,115 & 2,150 & 2,397 & 2,558 \\
Denmark & 2,565 & 2,988 & 3,208 & 3,484 & 3,915 & 4,360 & 4,749 \\
Germany & 35,504 & 38,351 & 42,103 & 46,639 & 49,544 & 52,315 & 54,581 \\
Japan & 97,111 & 100,216 & 104,421 & 105,813 & 106,531 & 112,027 & 119,514 \\
Netherlands & 3,575 & 3,753 & 4,708 & 7,980 & 5,883 & 4,847 & 5,178 \\
Sweden & 3,180 & 3,470 & 4,193 & 4,241 & 4,397 & 4,457 & 4,602 \\
Switzerland & 2,065 & 2,155 & 2,379 & 2,591 & 2,635 & 2,753 & 2,872 \\
United States & 265,713 & 269,613 & 264,440 & 253,045 & 245,577 & 240,433 & 236,291 \\
\end{tabular}

Source: OECD, Education at a glance

Table A3.8

Natural science degrees awarded (ISCED 6/7)

\begin{tabular}{|c|c|c|c|c|c|c|c|}
\hline & 1985 & 1986 & 1987 & 1988 & 1989 & 1990 & 1991 \\
\hline $\begin{array}{l}\text { Austria } \\
\text { Germany } \\
\text { Netherlands } \\
\text { Sweden } \\
\text { Switzerland } \\
\text { United states }\end{array}$ & $\begin{array}{r}524 \\
9,413 \\
1,685 \\
671 \\
1,148 \\
79,867\end{array}$ & $\begin{array}{r}450 \\
9,926 \\
1,732 \\
709 \\
1,170 \\
78,079\end{array}$ & $\begin{array}{r}520 \\
10,768 \\
1,906 \\
805 \\
1,325 \\
75,789\end{array}$ & $\begin{array}{r}544 \\
12,426 \\
2,899 \\
850 \\
1,398 \\
72,516\end{array}$ & $\begin{array}{r}628 \\
13,592 \\
2,180 \\
844 \\
1,462 \\
71,307\end{array}$ & $\begin{array}{r}673 \\
15,027 \\
1,812 \\
923 \\
1,524 \\
71,621\end{array}$ & $\begin{array}{r}780 \\
15,644 \\
1,752 \\
916 \\
1,595 \\
72,859\end{array}$ \\
\hline
\end{tabular}

Source: OECD, Education at a glance

Table A3.9

Mathematics and computing degrees awarded (ISCED 6/7)

\begin{tabular}{lrrrrrrr}
\hline & 1985 & 1986 & 1987 & 1988 & 1989 & 1990 & 1991 \\
\hline Austria & 405 & 372 & 413 & 580 & 576 & 585 & 573 \\
Germany & 3,296 & 3,755 & 4,087 & 4,490 & 5,127 & 5,616 & 6,423 \\
Netherlands & 199 & 229 & 300 & 474 & 458 & 359 & 380 \\
Sweden & 346 & 458 & 672 & 800 & 855 & 869 & 922 \\
Switzerland & 204 & 252 & 284 & 315 & 360 & 363 & 382 \\
United States & 64,954 & 70,510 & 69,064 & 64,244 & 59,950 & 56,889 & 54,337 \\
\hline
\end{tabular}

Source: OECD, Education at a glance

Table A3.10

Engineering degrees awarded (ISCED 6/7)

\begin{tabular}{lrrrrrrr}
\hline & 1985 & 1986 & 1987 & 1988 & 1989 & 1990 & 1991 \\
\hline Austria & 812 & 777 & 861 & 991 & 946 & 1139 & 1205 \\
Germany & 22,795 & 24,670 & 27,248 & 29,723 & 30,825 & 31,672 & 32,514 \\
Netherlands & 2,092 & 2,245 & 2,971 & 4,707 & 3,245 & 2,576 & 3,046 \\
Sweden & 2,163 & 2,303 & 2,716 & 2,591 & 2,698 & 2,665 & 2,764 \\
Switzerland & 713 & 733 & 770 & 878 & 813 & 866 & 895 \\
United States & 120,892 & 121,024 & 119,587 & 116,285 & 114,320 & 111,923 & 109,095 \\
\hline
\end{tabular}

Source: OECD, Education at a glance 
Table A3.11

Indicator of the share of vocational education students (second and third levels) in the total number of students at second and third levels

\begin{tabular}{|c|c|c|c|c|c|c|c|c|c|c|c|c|c|}
\hline & $\begin{array}{c}1975 \\
\%\end{array}$ & $\begin{array}{c}1980 \\
\%\end{array}$ & $\begin{array}{c}1981 \\
\%\end{array}$ & $\begin{array}{c}1982 \\
\%\end{array}$ & $\begin{array}{c}1983 \\
\%\end{array}$ & $\begin{array}{c}1984 \\
\%\end{array}$ & $\begin{array}{c}1985 \\
\%\end{array}$ & $\begin{array}{c}1986 \\
\%\end{array}$ & $\begin{array}{c}1987 \\
\%\end{array}$ & $\begin{array}{c}1988 \\
\%\end{array}$ & $\begin{array}{c}1989 \\
\%\end{array}$ & $\begin{array}{c}1990 \\
\%\end{array}$ & $\begin{array}{c}1991 \\
\%\end{array}$ \\
\hline $\begin{array}{l}\text { Netherlands } \\
\text { France } \\
\text { (West) Germany } \\
\text { United Kingdom } \\
\text { Sweden } \\
\text { Austria } \\
\text { United States } \\
\text { Japan }\end{array}$ & $\begin{array}{l}0.51 \\
0.35 \\
0.32 \\
0.16 \\
0.45 \\
0.25 \\
- \\
0.34\end{array}$ & $\begin{array}{l}0.53 \\
0.36 \\
0.33 \\
0.18 \\
0.45 \\
0.33 \\
-\overline{0} \\
0.32\end{array}$ & $\begin{array}{l}0.53 \\
0.36 \\
0.35 \\
0.19 \\
0.46 \\
0.33 \\
-- \\
0.32\end{array}$ & $\begin{array}{l}0.54 \\
0.40 \\
0.37 \\
0.19 \\
0.49 \\
0.35 \\
-0.30\end{array}$ & $\begin{array}{l}0.55 \\
0.38 \\
0.29 \\
0.20 \\
0.51 \\
0.37 \\
- \\
0.30\end{array}$ & $\begin{array}{l}0.55 \\
0.39 \\
0.31 \\
0.23 \\
0.51 \\
0.40 \\
-0.29\end{array}$ & $\begin{array}{l}0.56 \\
0.36 \\
0.60 \\
0.24 \\
-- \\
0.41 \\
-- \\
0.28\end{array}$ & $\begin{array}{l}0.57 \\
0.41 \\
0.48 \\
0.26 \\
0.51 \\
0.43 \\
- \\
0.28\end{array}$ & $\begin{array}{l}0.57 \\
0.38 \\
0.49 \\
0.27 \\
0.50 \\
0.43 \\
-0.28\end{array}$ & $\begin{array}{l}0.58 \\
0.39 \\
0.50 \\
0.28 \\
0.51 \\
0.53 \\
- \\
0.29\end{array}$ & $\begin{array}{l}0.59 \\
0.40 \\
0.50 \\
0.30 \\
0.51 \\
0.54 \\
-\quad .30\end{array}$ & $\begin{array}{l}0.59 \\
0.41 \\
0.49 \\
0.31 \\
0.52 \\
0.54 \\
-- \\
--\end{array}$ & $\begin{array}{l}0.43 \\
0.42 \\
-- \\
-- \\
-- \\
0.53 \\
-- \\
--\end{array}$ \\
\hline
\end{tabular}

Source: UNESCO

Table A3.13

Share of dual system students in the population aged 15-24

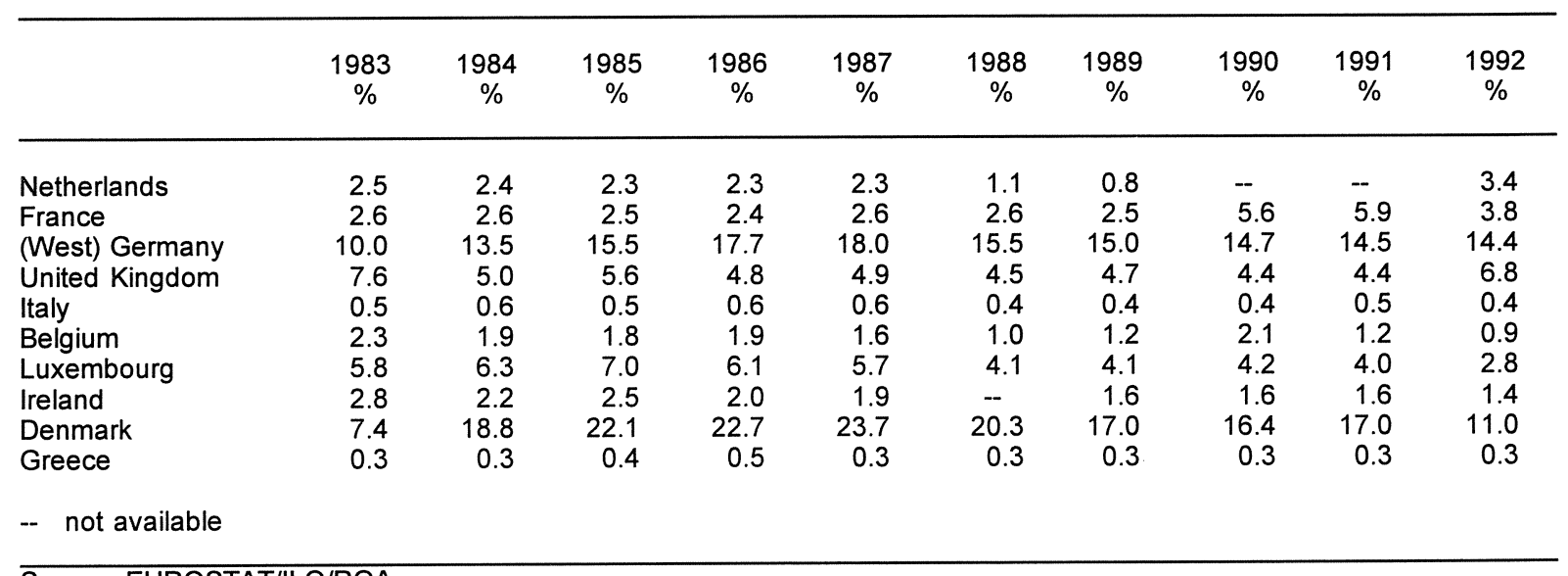

Source: EUROSTAT/LO/ROA

Table A3.15

Percentage share of primary apprenticeships in the labour volume of Dutch industrial sectors

\begin{tabular}{lcccccccccc}
\hline & $\begin{array}{c}1975 \\
\%\end{array}$ & $\begin{array}{c}1980 \\
\%\end{array}$ & $\begin{array}{c}1985 \\
\%\end{array}$ & $\begin{array}{c}1986 \\
\%\end{array}$ & $\begin{array}{c}1987 \\
\%\end{array}$ & $\begin{array}{c}1988 \\
\%\end{array}$ & $\begin{array}{c}1989 \\
\%\end{array}$ & $\begin{array}{c}1990 \\
\%\end{array}$ & $\begin{array}{c}1991 \\
\%\end{array}$ & $\begin{array}{c}1992 \\
\%\end{array}$ \\
\hline Metals and electrical & 3.7 & 5.1 & 5.0 & 6.2 & 7.0 & 7.0 & 6.9 & 6.6 & 4.6 & 4.6 \\
Building and wood & 0.9 & 1.9 & 1.9 & 2.2 & 2.3 & 2.4 & 2.5 & 2.8 & 2.6 & 2.5 \\
Foodstuffs & 1.9 & 2.9 & 3.4 & 3.7 & 4.0 & 4.4 & 4.2 & 4.1 & 4.5 & 4.5 \\
Process technologies & 0.5 & 0.9 & 1.4 & 2.2 & 2.0 & 1.8 & 1.9 & 2.0 & 1.9 & 1.9 \\
Printing & 0.7 & 1.6 & 1.2 & 1.5 & 1.8 & 1.8 & 2.0 & 2.0 & 1.6 & 1.2 \\
Transport & 0.2 & 0.3 & 0.5 & 0.6 & 0.6 & 0.7 & 3.7 & 4.0 & 3.6 & 4.4 \\
Textiles and clothing & 0.7 & 0.9 & 1.8 & 2.2 & 2.1 & 2.2 & 1.9 & 2.0 & 0.8 & 0.7 \\
\hline
\end{tabular}

Source: CBS/CPB/ROA 
Table A3.17

Percentage share of secondary apprenticeships in the labour volume of Dutch industrial sectors

\begin{tabular}{lcccccccccc}
\hline & $\begin{array}{c}1975 \\
\%\end{array}$ & $\begin{array}{c}1980 \\
\%\end{array}$ & $\begin{array}{c}1985 \\
\%\end{array}$ & $\begin{array}{c}1986 \\
\%\end{array}$ & $\begin{array}{c}1987 \\
\%\end{array}$ & $\begin{array}{c}1988 \\
\%\end{array}$ & $\begin{array}{c}1989 \\
\%\end{array}$ & $\begin{array}{c}1990 \\
\%\end{array}$ & $\begin{array}{c}1991 \\
\%\end{array}$ & $\begin{array}{c}1992 \\
\%\end{array}$ \\
\hline Metals and electrical & 0.6 & 1.3 & 1.4 & 1.8 & 2.2 & 2.6 & 3.2 & 3.6 & 2.9 & 3.0 \\
Building and wood & 0.4 & 0.4 & 0.6 & 0.7 & 0.8 & 0.9 & 1.0 & 1.1 & 1.0 & 1.1 \\
Foodstuffs & 0.6 & 1.4 & 1.3 & 1.6 & 1.8 & 2.0 & 2.2 & 2.4 & 2.8 & 2.8 \\
Process technologies & 0.0 & 0.1 & 0.0 & 0.1 & 0.6 & 1.1 & 1.3 & 1.6 & 1.6 & 1.8 \\
Printing & 0.2 & 0.3 & 0.2 & 0.3 & 0.6 & 0.6 & 0.7 & 0.7 & 0.7 & 0.6 \\
Transport & 0.0 & 0.0 & 0.0 & 0.0 & 0.0 & 0.0 & 0.4 & 0.3 & 0.3 & 0.6 \\
Textiles and clothing & 0.0 & 0.0 & 0.2 & 0.1 & 0.1 & 0.2 & 0.2 & 0.2 & 0.1 & 0.1 \\
\hline
\end{tabular}

\section{Source: $\mathrm{CBS} / \mathrm{CPB} / \mathrm{ROA}$}

\section{Table A3.20}

Unemployment among Dutch vocational (lower, intermediate and higher ${ }^{\star}$ ) school-leavers ${ }^{\star *}$ about one year after leaving school

\begin{tabular}{lccc}
\hline & $\begin{array}{c}\text { Cohort 1989/90 } \\
\%\end{array}$ & $\begin{array}{c}\text { Cohort 1990/91 } \\
\%\end{array}$ & $\begin{array}{c}\text { Cohort 1991/92 } \\
\%\end{array}$ \\
\hline Lower technical education & - & 2 & 5 \\
Total lower vocational education & -- & 4 & 6 \\
Intermediate technical education & -- & 3 & 5 \\
Total intermediate vocational education & -- & 4 & 17 \\
Higher technical education & 3 & 13 & 12 \\
\hline
\end{tabular}

* universities excluded

** excluding drop-outs

Source: HBO Monitor/RUBS/ROA

Table A3.21

Under-utilization ${ }^{\star}$ among Dutch vocational (lower, intermediate and higher ${ }^{\star \star}$ ) school-leavers ${ }^{\star \star \star}$ about one year after leaving school

\begin{tabular}{lccc}
\hline & $\begin{array}{c}\text { Cohort 1989/90 } \\
\%\end{array}$ & Cohort 1990/91 & \multicolumn{2}{c}{$\begin{array}{c}\text { Cohor 1991/92 } \\
\%\end{array}$} \\
\hline Lower technical education & - & 14 & 7 \\
Total lower vocational education & -- & 23 & 11 \\
Intermediate technical education & -- & 18 & 19 \\
Total intermediate vocational education & - & 22 & 23 \\
Higher technical education & 12 & 13 & 19 \\
Total higher vocational education & -- & 22 & 24 \\
\hline
\end{tabular}

* proportion of paid working school-leavers having jobs below their educational level

** universities excluded

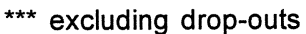

Source: HBO Monitor/RUBS/ROA 
Table A4.1

Participation in training by the labour force aged $15-49$

\begin{tabular}{|c|c|c|c|c|c|c|c|c|c|c|}
\hline & $\begin{array}{c}1983 \\
\%\end{array}$ & $\begin{array}{c}1984 \\
\%\end{array}$ & $\begin{array}{c}1985 \\
\%\end{array}$ & $\begin{array}{c}1986 \\
\%\end{array}$ & $\begin{array}{c}1987 \\
\%\end{array}$ & $\begin{array}{c}1988 \\
\%\end{array}$ & $\begin{array}{c}1989 \\
\%\end{array}$ & $\begin{array}{c}1990 \\
\%\end{array}$ & $\begin{array}{c}1991 \\
\%\end{array}$ & $\begin{array}{c}1992 \\
\%\end{array}$ \\
\hline $\begin{array}{l}\text { Netherlands } \\
\text { (West) Germany } \\
\text { United Kingdom } \\
\text { Italy } \\
\text { Belgium } \\
\text { Luxembourg } \\
\text { Ireland } \\
\text { Denmark } \\
\text { Greece }\end{array}$ & $\begin{array}{r}5.1 \\
- \\
6.8 \\
1.1 \\
1.9 \\
2.8 \\
3.1 \\
10.0 \\
0.6\end{array}$ & $\begin{array}{r}- \\
- \\
5.5 \\
6.8 \\
1.3 \\
2.1 \\
2.8 \\
2.9 \\
13.1 \\
0.6\end{array}$ & $\begin{array}{r}5.3 \\
7.4 \\
7.3 \\
1.4 \\
1.9 \\
2.9 \\
3.1 \\
14.6 \\
0.7\end{array}$ & $\begin{array}{r}- \\
8.5 \\
7.3 \\
1.4 \\
2.1 \\
3.1 \\
2.9 \\
15.6 \\
0.6\end{array}$ & $\begin{array}{r}6.4 \\
8.4 \\
8.0 \\
1.5 \\
1.6 \\
3.1 \\
3.0 \\
15.8 \\
0.6\end{array}$ & $\begin{array}{c}6.6 \\
8.6 \\
8.9 \\
1.6 \\
1.4 \\
2.9 \\
-- \\
13.7 \\
0.9\end{array}$ & $\begin{array}{r}7.2 \\
8.4 \\
9.6 \\
1.7 \\
1.6 \\
2.4 \\
2.9 \\
10.2 \\
0.9\end{array}$ & $\begin{array}{r}\overline{8.7} \\
10.4 \\
1.6 \\
1.7 \\
2.4 \\
3.9 \\
10.6 \\
1.0\end{array}$ & $\begin{array}{r}- \\
12.9 \\
11.1 \\
1.9 \\
1.7 \\
3.0 \\
3.3 \\
12.2 \\
1.1\end{array}$ & $\begin{array}{r}4.9 \\
4.0 \\
14.2 \\
0.8 \\
0.8 \\
2.5 \\
3.5 \\
11.5 \\
0.3\end{array}$ \\
\hline \multicolumn{11}{|c|}{ not available } \\
\hline
\end{tabular}

Source: EUROSTAT/ROA

Table A4.3

Participation in on-the-job training of the labour force aged 15-49

\begin{tabular}{lcccccccccc}
\hline & $\begin{array}{c}1983 \\
\%\end{array}$ & $\begin{array}{c}1984 \\
\%\end{array}$ & $\begin{array}{c}1985 \\
\%\end{array}$ & $\begin{array}{c}1986 \\
\%\end{array}$ & $\begin{array}{c}1987 \\
\%\end{array}$ & $\begin{array}{c}1988 \\
\%\end{array}$ & $\begin{array}{c}1989 \\
\%\end{array}$ & $\begin{array}{c}1990 \\
\%\end{array}$ & $\begin{array}{c}1991 \\
\%\end{array}$ & $\begin{array}{c}1992 \\
\%\end{array}$ \\
\hline Netherlands & 1.8 & - & 1.8 & -- & 1.7 & 1.6 & 1.8 & - & - & 3.3 \\
(West) Germany & 0.1 & 0.3 & 0.5 & 0.5 & 0.7 & 0.6 & 0.8 & 0.7 & 1.0 & 0.0 \\
United Kingdom & 0.9 & 1.7 & 2.0 & 1.9 & 2.2 & 2.5 & 2.7 & 2.9 & 3.1 & 7.9 \\
Italy & 0.4 & 0.3 & 0.3 & 0.3 & 0.3 & 0.3 & 0.4 & 0.4 & 0.5 & 0.7 \\
Belgium & 0.6 & 0.8 & 0.7 & 0.7 & 0.5 & 0.4 & 0.5 & 0.4 & 0.5 & 0.5 \\
Luxembourg & 0.6 & 0.4 & 0.4 & 0.5 & 0.7 & 0.8 & 0.7 & 0.7 & 1.0 & 1.3 \\
Ireland & 1.8 & 1.8 & 1.8 & 1.8 & 1.9 & - & 1.9 & 2.6 & 2.2 & 2.9 \\
Denmark & 1.8 & 2.1 & 2.6 & 3.8 & 3.5 & 3.5 & 2.9 & 3.0 & 3.2 & 8.3 \\
Greece & 0.1 & 0.2 & 0.2 & 0.2 & 0.1 & 0.3 & 0.2 & 0.2 & 0.2 & 0.2 \\
\hline
\end{tabular}

Source: EUROSTAT/ROA 